Florida A\&M University College of Law Scholarly Commons@ FAMU Law

Journal Publications

Faculty Works

Spring 2014

\title{
Opening Borders: African Americans and Latinos through the Lens of Immigration
}

Maritza I. Reyes

Florida Aઐ $M$ University College of Law, maritza.reyes@famu.edu

Follow this and additional works at: http://commons.law.famu.edu/faculty-research

Part of the African American Studies Commons, Immigration Law Commons, Latina/o Studies Commons, Law and Race Commons, and the Law and Society Commons

\section{Recommended Citation}

Reyes, Maritza I., Opening Borders: African Americans and Latinos through the Lens of Immigration, 17 Harv. Latino L. Rev. 1 (2014)

This Article is brought to you for free and open access by the Faculty Works at Scholarly Commons @ FAMU Law. It has been accepted for inclusion in Journal Publications by an authorized administrator of Scholarly Commons @ FAMU Law. For more information, please contact linda.barrette@famu.edu. 


\title{
OPENING BORDERS: AFRICAN AMERICANS AND LATINOS THROUGH THE LENS OF IMMIGRATION
}

\author{
Maritza I. Reyes*
}

\begin{abstract}
African-American and Latino voter turnout during the 2008 and 2012 presidential elections hit record numbers. Polls show that the immigration debate influenced Latino voter turnout and preference. Presidential candidate Barack Obama's voiced support of comprehensive immigration reform strengthened his lead among Latino voters in 2008 and, once in office, his executive policy of granting temporary protection to DREAMers solidified his lead among Latino voters in 2012. Both elections showed the power that minority groups can exert when they vote in support of the same candidate. If the demographic changes continue as currently estimated, African Americans and Latinos will contribute in large part to the making of the United States into a "majority-minority" nation and will play an increasingly important role in local and national politics. Therefore, it is important for Americans to become more inclusive of all minority groups and to expand discussions of race relations beyond the Black-White paradigm and discussions about immigration beyond the Latino-White paradigm.

As the polarized reactions to the Zimmerman verdict showed, there is much work to be done as the people of the United States continue the project of forming " $a$ more perfect Union." Honest assessments of how individuals and groups interact are crucial to opening borders and encouraging exchanges beyond socially constructed boundaries, like race, and racialized politics. African Americans and Latinos often compete with each other for political representation and other resources. In addition, the political consideration of immigration law and policy includes a racial dimension that is often camouflaged, but denial and silence about this reality do nothing to move the country forward. Therefore, immigration provides an opportunity to examine race relations and the potential for inter-group coalitions between African Americans and Latinos. For this reason, this Article also explores, through the lens of immigration, the role that race may play in the attitudes of African Americans and Latinos toward each other. One of the goals of this Article is to spark a candid dialogue that promotes a better understanding of race and its impact on interactions between African Americans and Latinos in the United States.
\end{abstract}

* Associate Professor of Law, Florida A\&M University College of Law; Harvard Law School Post-Graduate Research Fellow (2008-2011), LL.M., Harvard Law School; J.D. summa cum laude, Nova Southeastern University Shepard Broad Law Center. Initially, I thank Professor Nathan Cortez and other attendees for their feedback when I first presented the idea for this Article at the LatCrit XVI Conference. I also thank Professor Anthony R. Baldwin, Professor Carmen G. González, Professor Ronald C. Griffin, and Dean Kevin R. Johnson for their comments on earlier drafts. Finally, I extend my appreciation to my home institution for providing a summer research grant, to faculty members who attended my "brown bag" presentation, and to law school library personnel, particularly Phyllis Allen, Lorelle Anderson, and Linda Barrette for their assistance in locating sources. Finally, les doy muchas gracias to the editors of the Harvard Latino Law Review, especially Thomas Garza (the lead Article Editor assigned to my Article), Lily Axelrod, Indira Sordo, Lorell Guerrero, Ana Arias, Alexandra Drimal, Dayme Sanchez, Zara Lukens, Tyler Runge, and Amber Payne, for their efforts in finalizing this Article for publication.

${ }^{1}$ U.S. ConsT. pmbl. 
TABLE OF CONTENTS

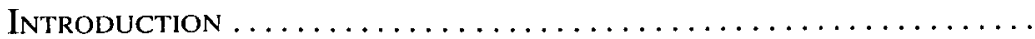

I. The Divide-and-Conquer Strategy: Media Coverage of the Latino Vote During the Hillary Clinton v. Barack Obama Democratic Primary................ 8

II. The Elephant in the Room: Race ................ 15

III. African Americans on Immigration............... 27

A. The African-American Experiences with Immigration and Migration ................................. 28

B. Nativism ............................... 32

C. Economics .............................. 36

D. Politics ................................ 41

IV. Civil Rights Coalitions ....................... 47

A. Racial Profiling ........................... 55

B. Education ................................ 57

C. Voting Rights........................... 58

D. Immigration .............................. 60

Conclusion $\ldots \ldots \ldots \ldots \ldots \ldots \ldots \ldots \ldots \ldots \ldots \ldots \ldots \ldots \ldots \ldots \ldots \ldots \ldots, \quad 62$

\section{INTRODUCTION}

"We may have all come on different ships, but we're in the same boat now."

The 2008 presidential campaign and election highlighted the political participation of the African-American ${ }^{3}$ and Latino ${ }^{4}$ populations. ${ }^{5}$ The in-

${ }^{2}$ Rev. Dr. Martin Luther King, Jr. Quotes, MLK DAY, http://mlkday.gov/plan/library/ communications/quotes.php (last visited Dec. 16, 2013).

${ }^{3}$ The terms African American, Asian American, Cuban American, Mexican American, and Native American are not hyphenated per Rule 3.83 of the Chicago Manual of Style, unless the terms are used as an adjectival phrase, in which case they are hyphenated. Additionally, with the exception of quotes from other authors, Black and White are capitalized in this Article when used to refer to groups of people socially constructed as races, in the same way as African American, Asian, Hispanic, Latino, and Native American. This change in general capitalization rules has also been adopted by other authors. See, e.g., Laura Ho, Catherine Powell \& Leti Volpp, (Dis)assembling Rights of Women Workers Along the Global Assembly Line: Human Rights and the Garment Industry, 31 HARv. C.R.-C.L. L. Rev. 383, 384 n.5 (1996); Juan F. Perea, The Black/White Binary Paradigm of Race: The "Normal Science" of American Racial Thought, 85 CAL. L. Rev. 1213 (1997).

${ }^{4}$ The terms "Latino" and "Hispanic" are used in this Article as umbrella terms that include "persons in the U.S. who trace their origins to Mexico, Puerto Rico, Cuba or other Spanish-speaking countries" while recognizing that there are intra-group differences based on nationality, geographic location in the United States, immigration experience, and socioeconomic factors. See Laura E. Gómez, What's Race Got to Do With It? Press Coverage of the Latino Electorate in the 2008 Presidential Primary Season, 24 ST. JoHn's J. LegAl. Comment. 425, 425 n.l (2009). Similar intra-group differences occur among African Americans. See K.J. Greene, "Copynorms," Black Cultural Production, and the Debate Over African-American Reparations, 25 CARDozo ARTS \& ENT. L.J. 1179, 1209 (2008). A comprehensive analy- 
creases of the Black and Latino populations impacted their voter turnout. ${ }^{6}$ Black voter turnout increased 4.9 percentage points from $2004(60.3 \%)$ to $2008(65.2 \%)$, nearly matching the White voter turnout rate $(66.1 \%){ }^{7} \mathrm{La}$ tino voter turnout also increased from $2004(47.2 \%)$ to $2008(49.9 \%){ }^{8}$ Due to close races, these groups' votes influenced the outcome of the elections in states where their presence is significant. ${ }^{9}$ Asian Americans also voted in record numbers, but their population numbers were not as considerable as those of African Americans and Latinos. ${ }^{10}$ Latinos made a historic contribution during the 2008 presidential race because the number of Latino voters was larger than in any prior presidential election. " Another factor that influenced the participation of minority ${ }^{12}$ groups was the presence of the first

sis of the intra-group differences within the U.S. Latino and African American communities is beyond the scope of this Article.

${ }_{5}^{5}$ The terms Black and African American, and Latino and Hispanic are used interchangeably throughout this Article. Latino is used as a gender-neutral term. The interchangeable use of the terms Black and African American reflects the different nomenclature that is used historically, scholarly, and ideologically. See Untold Stories: Civil. Rights, Libraries, and Black LibraRianship 7 (John Mark Tucker ed. 1998). The interchangeable use of the terms Hispanic and Latino reflects the use of different labels by Latinos in the United States. See generally Gerald A. López, Learning About Latinos, 19 ChICANO-LATINo L. Rev. 363, 392-99 (1998). It is worth nothing that the term "'Hispanic' has been rejected by some because of its association with 'the Spanish colonial power of centuries ago.' Those who object to this term prefer the term 'Latino' because it lacks any such connotation and 'is more inclusive and descriptive.'” Angel R. Oquendo, Re-Imagining the Latino/a Race, 12 HARv. BI.ACKI.ETTER L.J. 93, 96 (1995).

${ }^{6}$ Mark Hugo Lopez \& Paul Taylor, Dissecting the 2008 Electorate: Most Diverse in U.S. History, Pew Research Center, 1-4 (Apr. 30, 2009), http:/www.pewhispanic.org/files/reports/108.pdf.

${ }^{7}$ Id. at 4.

${ }^{8}$ Id.

${ }^{9}$ William H. Frey, How Did Race Affect the 2008 Presidential Election?, Population Studies CENTTE, 4-5 (Sept. 2009), http://www.frey-demographer.org/reports/R-2009-2 HowRaceAffect2008Election.pdf.

${ }^{10}$ Lisa Takeuchi Cullen, Does Obama Have an Asian Problem?, Time Magazine (Feb. 18, 2008), http://www.time.com/time/politics/article/0,8599,1714292,00.html. Much of the analysis in this Article could also include references and comparisons to the experiences of Asian Americans, but in the current immigration debate the increased visibility of Latinos has made them the main targets of racialized politics and the anti-immigrant movement. Michael Lwin, The Numbers Game: Covering Asian Americans and Post-Racial America, 15 Asian PAC. AM. L.J. 92, 104 (2009-10). The association of immigration with Latinos has contributed to the creation of a "Latino-White immigration paradigm." Id. at 107 (explaining how Asians are often left out of the immigration debate because their numbers are not significant). That said, it is important to recognize that coalitions with Asian Americans and other groups have played a crucial role in the comprehensive immigration reform movement and in the 2008 and 2012 presidential elections. "Future scholarship needs to focus more than it has on Latinos and Asian Americans-not less." Richard Delgado, Locating Latinos in the Field of Civil Rights: Assessing the Neoliberal Case for Radical Exclusion, 83 TEx. L. Rev. 489, 515 (2004) [hereinafter Delgado, Locating Latinos].

$"$ Gómez, supra note 4 , at $425-27$.

${ }^{12}$ In the United States, the term "minority" is a term used by scholars across disciplines to describe people who are "other than white." See, e.g., Kathryn J. Jervis, et al., Inner-City Hospital Closures: Financial Decision or Impediment to Access?, 38 No. 3 J. Hгalth Care FIN. (Aspen) 22, 30 (2012). However, some authors suggest that minority "is typically the term used by those in the dominant/mainstream culture to designate People and Communities of Color, as well as women." See, e.g., Tema Okun, The Emperor Has No Clothes: Teach- 
minority candidate, Barack Obama, ${ }^{13}$ the son of an immigrant, ${ }^{14}$ with a real potential to win the presidency. Obama turned out the most diverse voting demographics in the history of any U.S. presidential election. ${ }^{15}$ In 2012, President Obama's support of comprehensive immigration reform once again caused Latinos to vote and support him in overwhelming numbers, helping him to win a second term in office. ${ }^{16}$ In a speech on November 7, 2012, soon after his re-election, President Obama reiterated ${ }^{17}$ his promise to fix the immigration system. ${ }^{18}$

The 2010 U.S. Census figures confirm that the United States is becoming a more racially diverse country due to increases in populations of minority groups, mainly Asians, Blacks, and Latinos. ${ }^{19}$ The U.S. Census population percentage changes from 2000 to 2010 for the major population groups are as follows: Asians (3.6\% to $4.7 \%$ ), Blacks (12.1\% to $12.2 \%$ ),

ing About Race and Racism to People Who Don't Want to Know xiii (2010). The U.S. Census Bureau defines minority in some of its reports as "something other than non-Hispanic White alone." See, e.g., Karen R. Humes, Nicholas A. Jones \& Roberto R. Ramirez, U.S. Census Bureau, Overview of Race and Hispanic Origin: 2010, Census Burenu, 17 (Mar. 2011), http://www.census.gov/prod/cen2010/briefs/c2010br-02.pdf. In this Article the term minority means non-White.

${ }^{13}$ Deepa Iyer \& Priya Murthy, Courting the South Asian Vote: One Step Forward, Two Steps Back, 24 ST. JoHn's J. LeGAl COMMENT. 281, 281 (2009).

${ }^{14}$ Kristina M. Campbell, Imagining a More Humane Immigration Policy in the Age of Obama: The Use of Plenary Power to Halt the State Balkanization of Immigration Regulation, 29 St. Louis U. Pub. L. Rev. 415, 415 (2010).

${ }^{15}$ Iyer \& Murthy, supra note 13, at 281-82 (reporting the following voting percentages for President Obama: $96 \%$ of African Americans, $89 \%$ of Muslims, $67 \%$ of Latinos, and $63 \%$ of Asian Americans) (citations omitted).

${ }^{16}$ See Alan Lee, Immigration Issue a Big Reason for Obama Victory - Hispanics and Asian Americans Send a Message to the Republicans, Itw.com (Nov. 8, 2008), http://discuss .ilw.com/content.php?817-Article-Immigration-Issue-A-Big-Reason-For-Obama-Victory-His panics-And-Asian-Americans-Send-A-Message-To-The-Republicans-by-Alan-Lee-Esq.

${ }^{17}$ During his first presidential campaign, candidate Obama was very explicit about his support of comprehensive immigration reform. John Woolley \& Gerhard Peters, Barack Obama: Remarks to the National Association of Latino Elected and Appointed Officials in Washington, DC, The American Presidency Project (June 28, 2008), http://www.presiden cy.ucsb.edu/ws/index.php?pid=77557\#axzzl PySFLfhp (promising to begin working on comprehensive immigration reform during his first day in office); John Woolley \& Gerhard Peters, Barack Obama: Remarks at the 79th Annual League of United Latin American Citizens Convention in Washington, DC, The American Presidency Project (July 8, 2008), http://www .presidency.ucsb.edu/ws/index.php?pid $=77598 \#$ axzzl PySFLfhp (stating that he would make comprehensive immigration reform a priority during his first year in office); John Woolley \& Gerhard Peters, Barack Obama: Remarks at the 2008 National Council of La Raza Annual Meeting in San Diego, California, The Americnn Presijency Project (July 13, 2008), hitp:/ /www.presidency.ucsb.edu/ws/index.php?pid=77652\#axzz1 PySFLfhp (emphasizing that he would make comprehensive immigration reform "a top priority in [his] first year as President"); John Woolley \& Gerhard Peters, Barack Obama: Remarks to the Congressional Hispanic Caucus Institute Gala in Washington, DC, The American Presidency Project (Sept. 10, 2008), http://www.presidency.ucsb.edu/ws/index.php?pid=78613\#axzz1 PySFLfhp (expressing his support of comprehensive immigration reform).

${ }^{18}$ President Barack Obama, Remarks by the President on Election Night, THE WhITE House (Nov. 7, 2012), http://www.whitehouse.gov/the-press-office/2012/11/07/remarks-presi dent-election-night.

${ }^{19}$ Mark Mather, Kelvin Pollard \& Linda A. Jacobsen, Reports on Americn: FirSt Results From the 2010 Census, Population Reference Bureau, 7-8 (July 2011 ), http://www .prb.org/pdf1 1/reports-on-america-2010-census.pdf. 
Latinos (12.5\% to $16.3 \%$ ), and Whites $(69.1 \%$ to $63.7 \%) .^{20}$ The country is still majority White. ${ }^{21}$ However, according to the Population Reference $\mathrm{Bu}$ reau, "[t]he rapid increase in racial/ethnic minorities has put the United States on a fast track toward 'majority-minority' status, when less than half of the U.S. population will be non-Hispanic white."22 In terms of eligible voters, the majority are White. ${ }^{23}$ The age of the minority population is much younger; almost half of the U.S. population under eighteen (ineligible to register to vote) are minorities, but two-thirds of the voting-age population is White. ${ }^{24}$ Immigration has been a major reason for the increase of the minority population in recent decades, and future immigration will further determine if and when the U.S. population actually reaches "majority-minority" status. ${ }^{25}$

As demographic changes cause the United States to move away from a majority-White population and toward a "majority-minority" ${ }^{26}$ population, ${ }^{27}$ these demographic shifts increase the political power of the two largest minority groups-African Americans and Latinos. Consequently, more scholarship should analyze how the input and dynamics of these groups, in relation to each other, will influence the political and societal future of the United States. ${ }^{28}$ This necessity was identified as one of the concerns of Lat$\mathrm{Crit}^{29}$ scholars when they began a movement, ${ }^{30}$ among other things, to move

${ }^{20} I d$. at 7 . The U.S. Census has a history of under-reporting minorities and this trend continued in 2010. Id. at 6 . But see infra note 27 and accompanying text.

${ }^{21} \mathrm{Id}$. at 7 .

${ }^{22}$ Id. at 8 .

${ }^{23}$ Id. at 9 .

${ }^{24} \mathrm{Id}$.

${ }^{25}$ Id. at 3, 5, 8 (forecasting that the "majority-minority" status may be reached in 2042, but acknowledging that it all depends on future immigration and fertility trends). As of 2012, four states (California, Hawaii, New Mexico, and Texas) and the District of Columbia reached the "majority-minority" status designation. Newsroom, Asians Fastest-Growing Race or Ethnic Group in 2012, Census BuREau (June 13, 2013), http://www.census.gov/newsroom/releases/archives/population/cbl3-112.html.

26 "Majority-minority" population is terminology used in U.S. Census literature to describe a population that is less than 50\% non-Hispanic White. Mark Mather, Kelvin Pollard \& Linda A. Jacobson, Reports on America: First Results From the 2010 Census, Population REFERENCE BUREAU (July 2011), http://www.prb.org/pdf11/reports-on-america-2010-census .pdf.

${ }^{27}$ Id. at 8 . Some argue that the 2010 U.S. Census over-represented the rise of the "minority-majority" population because the Census over-counts minorities by allowing people to self-identify in one of the minority race groups or as Hispanics if they have a distant link to a minority heritage but, in reality, they are White. Matthew Yglesias, The Myth of MajorityMinority America, St.ATE (May 22, 2012), http://www.slate.com/articles/news_and_politics/ politics/2012/05/majority_minority_america_will_more_hispanics_and_asians_become_white _.html (citing as an example Professor Elizabeth Warren's (now a U.S. Senator) claimed Native-American heritage when she is actually White).

${ }^{28}$ See Gómez, supra note 4, at 454 (encouraging scholars to further examine the reasons for the alleged "meaningful divide" between Latinos and African Americans).

${ }^{29}$ LatCrit is the name assigned by its founding scholars, to "the first systematic, programmatic experiment in 'Latina/o legal studies' from within the legal academy of the United States." Margaret E. Montoya \& Francisco Valdes, "Latinas/os" and Latinalo Legal Studies: A Critical and Self-Critical Review of LatCrit Theory and Legal Models of Knowledge Production, 4 FIU L. REV. 187, 192 (2008). 
legal scholarship beyond the status quo. ${ }^{3 !}$ LatCrits sought to consider how the diverse racial groups should collaborate with each other. ${ }^{32}$

How do we as African-Americans, we as White-Americans, we as Asian-Americans, we as Latino/Latina Americans participate together in struggles that involve people who are not ourselves? Fundamentally, we have to figure out how to hear what other people are saying, how to participate in the struggle of those others who are involved with us in the larger struggle to reduce racial and gender oppression and how to understand what this project as a racial, ethnic, or nationality concern ought to entail and ought to make for us. ${ }^{33}$

As this Article approached its final stage, the verdict in the Zimmerman case was rendered. ${ }^{34}$ This case polarized the country along perspectives about race in America. ${ }^{35}$ It reminded the nation that we are still divided in our experiences with racial injustice. ${ }^{36}$ It also reminded us why it is important to explore and understand how race influences our individual and group views on legal, political, and social issues. Authors who choose to challenge the status quo open themselves to criticism and to being labeled controversial. ${ }^{37}$ However, some of us have to be willing to open critical dialogues and propose solutions about issues of our time that impact nearly every aspect of law and society. Great efforts have been made during the writing of this Article not to essentialize the experiences of African Americans and Latinos because members of these communities are not monolithic. ${ }^{38}$ To "essential-

${ }^{30}$ Some of the discussions and articles presented during the first LatCrit symposium (LATCRIT I) were published in the second volume of the Harvard Latino Law Review in 1997. Symposium-LatCrit Theory: Naming and Launching a New Discourse of Critical Legal Scholarship, 2 Harv. Latino L. Rev. 1 (1997). See also LatCrit Symposia, List of Published Proceedings, L^'TCkIT, http://latcrit.org/content/publications/latcrit-symposium/ (including link to the articles in the first annual LatCrit symposium after LATCRIT I).

${ }^{31}$ See generally Jerome McCristal Culp, Jr., Latinos, Blacks, Others, and the New Legal Narrative, 2 HaRv. LATINO L. REv. 479 (1997).

${ }^{32} \mathrm{Id}$. at $48 \mathrm{I}$.

${ }^{33} \mathrm{ld}$. at 481-82.

${ }^{34}$ Lizette Alvarez \& Cara Buckley, Zimmerman Is Acquitted in Killing of Trayvon Martin, N.Y Times (July 14, 2013), http://www.nytimes.com/2013/07/15/us/george-zimmerman-ver dict-trayvon-martin.html. George Zimmerman was found not guilty by a jury in the criminal prosecution for killing Trayvon Martin. Id.

${ }^{35}$ Adam Nagoumey, Prayer, Anger and Protests Greet Verdict in Florida Case, N.Y Times (July 14, 2013), http://www.nytimes.com/2013/07/15/us/debate-on-race-and-justice-isrenewed.html?hp.

${ }^{36}$ See, e.g., Maritza Reyes, A Latina Law Professor's Personal Perspective after the Zimmerman Trial Verdict, IMMigrationProf Blog (July 15, 2013), http://lawprofessors.typepad .com/immigration/2013/07/a-latina-law-professors-personal-perspective-after-the-zimmermantrial-verdict-by-professor-maritza-.html [hereinafter Reyes, A Latina Law Professor's Personal Perspective].

${ }^{37}$ See Elvia R. Arriola, Tenure Politics and the Feminist Scholar, 12 COLUM. J. GENDER \& L. 532, 536, 538 (2003).

${ }^{38}$ Montoya \& Valdes, supra note 29, at 190-94 ("Latinas/os" are understood to comprise a mixed bag of people of diverse characteristics, including "race, color, class, ethnicity, national origin, immigration status, religion, gender, sexual orientation, dis/ability, ideology, and 
ize" minorities means to ascribe certain characteristics and experiences to all individuals within a particular group. ${ }^{39}$ However, notwithstanding individual differences, "there are still issues where which race [a person is] makes a difference in perception. And that perception informs political views and attitudes." ${ }^{40}$ This is why race and its impact on individual and group actions and reactions are analyzed in this Article.

There is ample legal scholarship analyzing racial dynamics between Whites and minorities, but the taboo subject ${ }^{41}$ of how minorities engage in "racialized politics" 42 around political issues, such as the immigration debate, is in its early stages. ${ }^{43}$ This Article examines, through the lens of immigration, how demographic shifts, race, and politics affect coalitions between African Americans and Latinos. ${ }^{44}$ In this Article, it is taken as established that African Americans and Latinos are socially-constructed racial groups in the United States. ${ }^{45}$ Part I illustrates how the media "racialized" the Latino vote during the 2008 Democratic Primary elections when the majority of Latinos in those early elections supported U.S. Senator Hillary Clinton, a White woman, rather than U.S. Senator Barack Obama, a Black man. ${ }^{46}$ This Part shows the need for more nuanced discussions about race and race relations, and explains why Americans should not rely on incomplete and misguided media representations of Black-Brown alliances and conflicts. ${ }^{47}$ Part II considers the elephant in the room-race-in relation to interactions between African Americans and Latinos. Racism is generally not cited, at least not in a direct and explicit way, when scholars examine the reasons

others.") (citations omitted); Judith G. Greenberg, Erasing Race from Legal Education, 28 U. Mich. J.L. REF, 51, 97 n.202 (1994) ("Gender, class, geographic area, and national origin, among other factors, are all critical to any discussion of African American identities.").

${ }^{39}$ See Nancy Leong, Racial Capitalism, 126 Harv. L. Rev. 2151, 2168 (2013) (citing Richard T. Ford, Racial Culture 59-64 (2005)).

${ }^{40}$ Anthony C. Thompson, Unlocking Democracy: Examining the Collateral Consequences of Mass Incarceration on Black Political Power, 54 How. L.J. 587, 605 (2011).

${ }^{41}$ Race is still viewed as a taboo subject and its mere mention can be interpreted as an act of racism. Tanya Katerí Hernández, Racial Subordination in Latin America 177 (2013) [hereinafter Hernández, Racial Subordination].

42 "Racialized politics" is a concept that explains that individuals and groups develop and exercise their political views through the prism of race. Racialized Polmtics 237 (David $O$. Sears, Jim Sidanius \& Lawrence Bobo eds., 2000).

${ }^{43}$ We need legal journals that examine the difficult issues of our time, including immigration and inter-group conflict between different racial groups. Kevin R. Johnson, Dedication of "The Scholar: St. Mary's Law Review of Minority Issues," 1 SchOl.AR 1 (1999). LatCrit scholars have made efforts to explore minority-on-minority conflicts and the limitations of the Black-White binary. See, e.g., Leslie Espinoza \& Angela P. Harris, Afterword: Embracing the Tar-Baby-LatCrit Theory and the Sticky Mess of Race, 10 L^ RAZA L.J. 499 (1998); Athena D. Mutua, Shifting Bottoms and Rotating Centers: Reflections on LatCrit III and the Black White Paradigm, 53 U. Miami L. Rev. 1177 (1999); Robert S. Chang \& Neil Gotanda, The Race Question in LatCrit Theory and Asian Jurisprudence, 7 NEv. L.J. 1012 (2007).

${ }^{44}$ This Article addresses issues that must be confronted in order to educate and understand both communities. See Gómez, supra note 4, at 454 (advocating that we need to begin raising specific questions about the Latino-African American divide because avoiding the topic does not advance flourishing Black-Brown coalitions).

\footnotetext{
${ }^{45}$ See id. at 431.

${ }^{46}$ See id. at 444-50.

${ }^{47}$ Arlene Dávila, Latino Spin 168 (2008).
} 
why African Americans sometimes join with Whites in opposition to immigration and immigrants. ${ }^{48}$ But, as the events surrounding the Zimmerman case demonstrate, avoiding the issues of race and racism, including within minority communities, does not cure the problem. When minority groups fail to acknowledge that they are not immune from racist tendencies, they repeat the learned cycle of oppression against members of other groups, including against other people of color. ${ }^{49}$ This Article confronts race and racism candidly in an effort to put them on the table as conscious and unconscious reasons for the lack of support for immigration reform in some African-American circles.

Part III examines the views of African Americans about Latino immigration, thereby expanding beyond the usual Latino-White immigration paradigm $^{50}$ to a Black-Latino paradigm. Paradigms center the interests of particular communities. ${ }^{51}$ It is valuable to consider the interests of African Americans vis-à-vis Latinos in the immigration debate. This Part includes, by way of background, a brief discussion of the African American experiences with immigration and migration. Finally, this Part challenges the main reasons cited for anti-immigration positions: nativism, economics, and politics. Part IV describes some of the historical civil rights struggles of African Americans and Latinos and analyzes why the groups should collaborate in the fight for civil rights for all. The communities are disenfranchised, including through racial profiling, segregated and substandard education systems, denial of voting rights, and detrimental immigration policies. These experiences demonstrate that the groups should work together in support of common interests. In conclusion, the Article proposes that African-American and Latino interactions and coalitions may set the tone for the sociopolitical future of the nation.

\section{The Divide-and-Conquer Strategy: Media Coverage of the Latino Vote During the Hillary Clinton v. Barack Obama Democratic Primary}

Media coverage shapes the narratives during elections, especially during presidential elections. ${ }^{52}$ The media has power to construct and push

${ }^{48}$ This is not to suggest that "minority-on-minority conflict and other ethno-racial fault lines" have not been analyzed before. See, e.g., Chang \& Gotanda, supra note 43, at 1021. But, as it respects to the lack of Black support on issues that impact immigrants and their communities, the reason usually given is the competition for jobs. See, e.g., Kevin R. Johnson, Latinas/os and the Political Process: The Need for Critical Inquiry, 81 OR. L. Rev. 917, 93336 (2002) [hereinafter Johnson, Latinas/os and the Political Process].

${ }^{49}$ See Taunya Lovell Banks, Both Edges of the Margin: Blacks and Asians in Mississippi Masala, Barriers to Coalition Building, 5 Asian L.J. 7, 10 (1998). 107.

${ }^{50}$ Immigration is often analyzed from a Latino-White paradigm. Lwin, supra note 10, at

${ }^{51}$ Id.

52 Joanna Lian Pearson \& Donna Rouner, The 2008 Elections and the Role of Gender Among Young Voters, 24 St. John's J. Legal Comment. 343, 354 (2009). 
agendas. ${ }^{53}$ Race and gender were front and center like never before during the 2008 primary season in the race for the Democratic Party's presidential nomination. ${ }^{54}$ During the primary elections, Blacks made up roughly $13 \%$ of the U.S. population, ${ }^{55}$ but their influence in the Democratic primary was much larger due to their Democratic leanings. ${ }^{56}$ For example, exit polls in South Carolina indicated that Blacks made up 54\% of the 2008 Democratic primary electorate, despite only being $28 \%$ of the state's population. ${ }^{57}$ In the early months of the Democratic primary race, a CBS News poll showed that the Black vote was divided $52 \%$ for Clinton and $28 \%$ for Obama. ${ }^{58}$ Some Black leaders, such as civil rights activist Al Sharpton and U.S. Representative John Lewis, did not initially support Obama's candidacy. ${ }^{59}$ During the primaries, African-American author and poet Maya Angelou supported Hillary Clinton. ${ }^{60}$ Other prominent African-American women, like Donna Brazile, a former Bill Clinton campaign manager, felt torn between race and gender. ${ }^{61}$ Some African Americans questioned Obama's "blackness" because of his immigrant father (a Kenyan), his White mother, and his formative years raised by White grandparents in Hawaii. ${ }^{62}$ But the initial Black voting trend and anti-Obama apprehensions changed as the primary race progressed. ${ }^{63}$ African-American voters ended up supporting Obama during the primaries by a margin of $90 \%$ and carried him to victory in states where their presence was significant. ${ }^{64}$ Thereafter, during the presidential election,

${ }^{53}$ Gómez, supra note 4, at 443-44.

${ }^{54}$ Meta G. Carstarphen, Uncovering Race in 2008: Media, Politics and the Reporter's Eye, 24 Sr. John's J. Legal Comment. 403, 412 (2009); Joanna Lian Pearson \& Donna Rouner, The 2008 Elections and the Role of Gender Among Young Voters, 24 ST. JoHn's J. Legal Comment. 343, 353-54 (2009); Carolyn M. Byerly, Women, the Economy and News: Analysis of the 2008 U.S. Primary Coverage, 24 St. John's J. Legal Comment. 387, 388 (2009).

${ }^{55}$ Paul Taylor \& Richard Fry, Hispanics and the 2008 Election: A Swing Vote?, PEw HISPANIC CENTER, 13 (Dec. 6, 2007), http://www.pewhispanic.org/files/reports/83.pdf.

${ }^{56}$ See Exit Polls: South Carolina, CNN (Jan. 25, 2008), http://www.cnn.com/ELECTION/ 2008/primaries/results/epolls/\#SCDEM; American Fact Finder, CENSus BurEAu, http://fact finder2.census.gov/faces/tableservices/jsf/pages/productview.xhtml?pid=ACS_08_1YR_DP5 \&prodType $=$ table.

${ }^{57} I d$.

${ }^{58}$ Perry Bacon, Jr., Can Obama Count on the Black Vote?, Time Magazine (Jan. 23, 2007), http://www.time.com/time/nation/article/0,8599,1581666,00.html.

${ }^{59}$ Id; Kevin Merida, Obama Wave Stuns Clinton's Black Supporters, Wash. Post (Feb. 19, 2008), http://www.washingtonpost.com/wp-dyn/content/article/2008/02/18/AR200802180 2364.html.

${ }^{60}$ David Ingram, Decision 2008: The N.C. Primary: Clinton Works to Sway Black Women, Charlotrie ObServer, Apr. 19, 2008, at 2-3, available at 2008 WLNR 7295935.

${ }^{61}$ Donna Brazile, Making History: Race, Gender, and the Media in the 2008 Elections, 24 St. John's J. Legal Comment. 271, 274 (2009).

${ }^{62}$ Rachel L. Swarns, So Far, Obama Can't Take Black Vote for Granted, N.Y. Times (Feb. 2, 2007), http://www.nytimes.com/2007/02/02/us/politics/02obama.html.

${ }^{63}$ See, e.g., Lewis Switches from Clinton to Obama, CNN Politicalticker (Feb. 27, 2008), http://politicalticker.blogs.cnn.com/2008/02/27/lewis-switches-from-clinton-to-obama/.

${ }^{64}$ Mark Z. Barabak, Obama Cruises; Clinton Clings, L.A. Times, May 7, 2008, at 1, available at 2008 WLNR 8511389. 
Obama received the overwhelming support of African-American voters95\% of their votes. ${ }^{65}$

Latinos numbered approximately $15.5 \%$ of the U.S. population during the 2008 election cycle. ${ }^{66}$ Second-generation Latinos are the fastest growing electorate within the Latino population. ${ }^{67}$ However, Latinos made up less than $9 \%$ of the eligible electorate because some Latinos were too young to vote and some were not U.S. citizens. ${ }^{68}$ The Democratic primary race on Super Tuesday 2008 highlighted the role that the Latino vote played in helping Clinton to continue in the race for the Democratic Party's nomination. ${ }^{69}$ In California, the Latino voter turnout in 2008 was $30 \%$ compared to $16 \%$ in $2004{ }^{70}$ In Texas, Latino voters comprised $32 \%$ in 2008 compared to $24 \%$ in $2004 .{ }^{71}$ Latinos favored Clinton over Obama in the California primary $(63 \%$ to $35 \%$ ) and Texas primary (66\% to $32 \%) .72$ "Clinton would have lost both states were it not for the strong support she received from Latinos." 73

During the primary elections, the media emphasized the decisive role that Latinos played in ensuring Clinton's success in key races. ${ }^{74}$ In light of the crucial participation of Latinos in these political races, between Clinton, a White candidate who would have become the first woman president, and Obama, a Black candidate, who would become the first African-American president, some reporters and political analysts attributed the Latino voting trend to the "conflict" between the African-American and Latino communities. $^{75}$ Some injected race into the alleged conflict and asserted that Latinos would not vote for Obama simply because he is Black. ${ }^{76}$ The 2008 presidential election proved these predictions wrong because Latinos voted overwhelmingly for Obama. ${ }^{77}$ But this episode in U.S. history demonstrates why

${ }^{65}$ Mark Hugo Lopez \& Paul Taylor, Dissecting the 2008 Electorate: Most Diverse in U.S. History, Pew Hispanic Center, iii (Apr. 30, 2009), http://www.pewhispanic.org/files/reports/ 108.pdf.

${ }^{66}$ Susan Minushkin \& Mark Hugo Lopez, The Hispanic Vote in the 2008 Democratic Presidential Primaries, Pew Hispanic CENTter, 4 (Feb. 21, 2008), http://www.pewhispanic .org/files/reports/86.pdf.

${ }^{67}$ Taylor \& Fry, supra note 55, at 13.

${ }^{68}$ Minushkin \& Lopez, supra note 66.

${ }^{69} \mathrm{Id}$.

${ }^{70}$ Id. at 1 .

${ }^{71}$ Id.

${ }^{72}$ Id. at 2. Asian American voters favored Clinton over Obama in California and New York by margins of $75 \%$ to $23 \%$ and $86 \%$ to $14 \%$, respectively. Nancy Wang Yuen, The Asian American Vote: The Role of Race in News Media Coverage of the 2008 Democratic Primaries, 24 St. John's J. LeGAL COMment. 421, 421 (2009).

${ }^{73}$ Minushkin \& Lopez, supra note 66, at 1.

${ }^{74}$ See Gómez, supra note 4, at 444.

${ }^{75} \mathrm{Id}$. at $427,443-44$.

${ }^{76}$ Editorial, Democratic Politics Has Become Surreal, HatTiesburg Am. (Hattiesburg, Miss.), Feb. 1, 2008, available at 2008 WLNR 27155208. Some media outlets also alleged that racism against Blacks was the reason for the low support that Obama received in the Asian-American communities during the Democratic primary in California. Wang Yuen, supra note 72 , at $422-23$. Obama. Id.

${ }^{77}$ Wang Yuen, supra note 72, at 424. The majority of Asian Americans also voted for 
it is important for minority groups to avoid being pitted against each other without fully exploring the full complexity and context of the issues. ${ }^{78}$

"Ignoring how society racializes one group at the expense of another . . . is risky business. To understand when one is being manipulated or used to suppress someone else, each minority group must attend to the broader scale." 79 African Americans and Latinos are often portrayed in stereotypical ways in public discourse and the media promulgates these stereotypes, which often go unchallenged in our education system. ${ }^{80} \mathrm{~A}$ more in-depth analysis of the Latino vote shows race-neutral explanations for the voting trend during the Clinton-Obama primary race. ${ }^{81}$ Clinton had a fifteen-year history with Latino communities. ${ }^{82}$ This relationship developed as a result of her husband's popularity with the group. ${ }^{83}$ Former President Bill Clinton maintained a $70 \%$ approval rating among Latinos, including during his impeachment, because, as Los Angeles Mayor Antonio Villaraigosa explained, "Latinos remembered the Clinton administration as 'great years for working families."'84

Surveys show additional factors that motivated Latinos to vote for Hillary Clinton. For many Latino women gender was important and those voters who identified gender as important were more likely to vote for Clinton. ${ }^{85}$ The majority of Latino voters were women $(56 \%)$ and they favored Clinton on Super Tuesday. ${ }^{86}$ This trend was in line with Clinton's strong support, in general, from women voters (except for Black women). ${ }^{87}$ More Latinos than Whites identified the economy as the most important issue in the election. ${ }^{88}$ Clinton had been identified by some voters as the best candidate to deal with the economy. ${ }^{89}$ Hispanic voters were less likely to

${ }^{78}$ Id. The media also fueled tensions between African Americans and Koreans in Los Angeles after the acquittal of the police officers in the Rodney King beating. KATHERYN Russell-Brown, Protecting Our Own: Race, Crime, and African americans 5 (Joe R. Feagin ed., 2006).

${ }^{79}$ Richard Delgado, Derrick Bell's Toolkit-Fit to Dismantle That Famous House?, 75 N.Y.U. L. REV. 283, 289-90 (2000).

${ }^{80}$ Latinas/os in the United Strates: Changing the Face of América xvi (Havidán Rodríguez, Rogelio Sáenz \& Cecilia Menjívar, eds., 2008).

${ }^{81}$ Latinos who identified race as important were as likely to vote for Clinton as for Obama. Ingram, supra note 60, at 2-3. This was different for Whites-those who identified race as important were more likely to vote for Clinton. Id.

${ }^{82}$ Alex Johnson, For Clinton, Latino Vote Could Swing the Deal, NBCNEws.com (Feb. 8, 2008, 8:06 AM), http://www.msnbc.msn.com/id/23058132/from/ET/.

${ }_{83}$ Id. In 1992 and 1996 , Bill Clinton received $61 \%$ and $72 \%$ of the Latino vote. JUAN Gonzalez, Harvest of Empire: A History of Latinos in America 186 (2001).

${ }^{84}$ Johnson, supra note 82.

${ }^{85}$ Minushkin \& Lopez, supra note 66 , at 3.

${ }^{86} \mathrm{Id}$. at 8 .

${ }^{87}$ Ingram, supra note 60.

${ }^{88} \mathrm{Id}$.

${ }^{89}$ James Romoser, Democrats Ask Who Can Best Win Election: Clinton, Obama Scrap for N.C. Votes, WinSTON-SAlEm J., Apr. 6, 2008, available at 2008 WLNR 6461752. 
have a college education than Black and White voters ${ }^{90}$ and Clinton was highly favored by non-college educated voters (except for Black voters). ${ }^{91}$ Additionally, old political wounds between African Americans and Latinos may have played a role in the primary elections. For example, lawyer and civil rights activist Adelfa Callejo, ${ }^{92}$ a Clinton supporter in Texas, told a local television station that Latinos would not support an African American candidate because "“[w] hen Blacks had the numbers, they didn't do anything to support [Latinos]. . . . They always used [Latinos'] numbers to fulfill their goals and objectives, but they never really supported us, and there's a lot of hard feelings about that. I don't think we're going to get over it anytime soon." "'93 This political experience is not limited to Texas. In California, in 2001, in his first run for mayor of Los Angeles, MexicanAmerican Antonio Villaraigosa received $80 \%$ of the Latino votes. ${ }^{94}$ But he lost the election when $80 \%$ of African Americans voted for the White candidate. ${ }^{95}$ This further contributed to the tension between the two groups. ${ }^{96} \mathrm{~A}$ few years earlier, African Americans along with anti-immigrant groups had overwhelmingly supported the passage of a Los Angeles County ordinance

${ }^{10}$ Minushkin \& Lopez, supra note 66 , at 5.

${ }^{91}$ Kathy Kiely \& Jill Lawrence, Clinton Makes Case for Wide Appeal, USA TOD^Y (May 8, 2008, 2:31 PM), http://www.usatoday.com/ncws/politics/election2008/2008-05-07-clintonin terview_N.htm.

${ }_{92}$ Callejo was an ardent activist for her community.

In 1961, Callejo became the first Hispanic woman to graduate from law school at Southern Methodist University. She was 37 and one of only three women to graduate from the law school that year. . . . Her law degree was an essential weapon for fighting injustice, Callejo once said. She spoke fast and forcefully, as though perpetually in court and well-caffeinated. Until her 2012 brain surgery, she practiced law at her low-key office near Central Expressway and Fitzhugh Avenue. It was there that she nurtured the law careers of other young Mexican-American attorneys, including Marcos Ronquillo, who would become her law firm partner from 1983 to 1986. "She could only get a job after law school as a legal secretary," Ronquillo recalled. "She was a Mexican-American woman with a law degree from SMU." That's why Callejo started her own practice, he said.

Dianne Solís \& Joe Simnacherd, Longtime Dallas Lawyer, Civil Rights Activist Adelfa Callejo Dies at 90, DALLASNEwS (Jan. 25, 2014), http://www.dallasnews.com/obituary-headlines/ 20140125-longtime-dallas-lawyer-civil-rights-activist-adelfa-callejo-dies-at-90.ece. Callejo received many awards for her work as an attorney and as an advocate for her community, including the Dallas Hispanic Bar Association's (an organization of which she was a founding member) "La Luz" (The Light) Award and the State Bar of Texas "Texas Legal Legend" Award. In Memoriam: Adelfa Callejo-The DHBA Mourns the Loss of a Tireless Leader, DAllas Hispanic BAr Association (last visited Jan. 29, 2014), http://www.dallashispanicbar .com/?page id=1816; HNBA Mourns the Loss of Adelfa Botello Callejo, HiSPANIC NA'TIONAL Bar Association (last visited Jan. 29, 2014), http://www.hnba.com/hnba-mourns-loss-adelfabotello-callejo/. Callejo died at the age of 90 on Saturday, January 25, 2014. Dianne Solís \& Joe Simnacherd, Longtime Dallas Lawyer. Civil Rights Activist Adelfa Callejo Dies at 90, DAILAASNEwS, Jan. 25, 2014, http://www.dallasnews.com/obituary-headlines/20140125-longtime-dallas-lawyer-civil-rights-activist-adelfa-callejo-dies-at-90.ece. May she rest in peace.

${ }^{93}$ Kathleen Parker, Some Wrongs Do Carry Bits of Truth, S. FlA. Sun-Sentinel, Mar. 20 , 2008 , at 23A, available at 2008 WLNR 5391518.

${ }_{94}$ Johnson, Latinas/os and the Political Process, supra note 48, at 934.

${ }^{95}$ Id.

${ }^{96}$ See id. 
that prohibited curbside job solicitation by predominantly Latino day laborers. ${ }^{97}$ The ordinance was struck down on First Amendment grounds; therefore, the court avoided reviewing the "racial undercurrent to its passage." 98 Eventually, Villaraigosa garnered the support of the African-American community and won the mayoral seat when he ran again in $2005 .{ }^{99}$

The analysis of the voting trend of Latinos shows that the blanket allegation made during the 2008 primaries that Latinos would not vote for a Black candidate because of group conflict or solely on the basis of race was absolutely reckless and false. ${ }^{100}$ Ultimately, Obama obtained the Latino vote because he included Latinos in his message of change and promised to address issues important to Latinos, such as comprehensive immigration reform. ${ }^{101}$ A Latina columnist put it this way, "Obama need[ed] to show Latinos that he will stand with them, and for them, even when they are not in the room. Latino voters' loyalty [wa]s Obama's to win."102 The final presidential voting statistics prove that the media's racial hype was manufactured. ${ }^{103}$ Latinos voted overwhelmingly for Obama by a margin of $67 \%$ compared to $31 \%$ in favor of U.S. Senator John McCain. ${ }^{104}$ Latinos secured a win for Obama in four key states (Colorado, Florida, Nevada, and New Mexico) that had tilted in favor of President George W. Bush four years earlier. ${ }^{105}$

During the 2012 presidential election Hispanics continued to support President Obama despite his failure to introduce comprehensive immigration reform and a path to legalization for the undocumented immigrant popula-

${ }^{97}$ Id. at $933-34$.

${ }^{98} \mathrm{Id}$. Courts often ignore the racial aspect of laws that disparately impact Latinos, ruling on other grounds without addressing the underlying race discrimination aspect. Id. at $934 \mathrm{n.85}$ (citing Proposition 187 and anti-bilingual education measures).

${ }^{99}$ Jesse Jackson, No Voting Division Splits Latinos, African Americans, ChI. Sun-Times, Feb. 12, 2008, at 23, available at 2008 WLNR 2677414. See also Adam Nagourney \& Jennifer Steinhauer, Campaign Now Veers into Ethnic Backyards Blacks and Hispanics Share Uneasy History, INT'L. HERAI.D TRIB., Jan. 16, 2008, at 2, available at 2008 WLNR 867950 ("Villaraigosa lost his first effort to become mayor, in 2001, to a white, James Hahn, who won 80 percent of the black vote. In a rematch in 2005 , Villaraigosa was elected with 50 percent of the black vote.").

${ }^{100}$ The media hypes the tension between the groups without a full discussion of the underlying reasons for the perceived conflicts. See Karla Mari McKanders, Black and Brown Coalition Building During the "Post-Racial" Obama Era, 29 ST. Lovis U. Pub. L. Rev. 473, 492 (2010) [hereinafter McKanders, Black and Brown Coalition Building].

${ }^{101}$ See generally supra note 17; John Woolley \& Gerhard Peters, Barack Obama: Remarks in Coral Gables, Florida, The American Presidency Project (Sept. 19, 2008), http:// www.presidency.ucsb.edu/ws/index.php?pid=78653\#axzzl PySFLfhp; John Woolley \& Gerhard Peters, Barack Obama: Remarks in Miami, Florida, The American Presidency Project (Oct. 21, 2008), http://www.presidency.ucsb.edu/ws/index.php?pid=84617\#axzz1PySFLfhp. ${ }^{102}$ Mary Sanchez, Barack Obama Must Seek Latino Support, S. Fla. Sun-Sentinel, Mar. 14, 2008, at $21 \mathrm{~A}$, available at 2008 WLNR 5032763.

${ }^{103}$ Mark Hugo Lopez, The Hispanic Vote in the 2008 Election, Pew Hispanic Censter i-ii

(Nov. 5, 2008), http://www,pewhispanic.org/files/reports/98.pdf.

${ }^{104}$ Id. at 32 .

${ }^{105}$ Goméz, supra note 4 , at 427. 
tion during his first term in office. ${ }^{106}$ They continued to support him despite their opposition to his policy of increased deportations of Latinos. ${ }^{107}$ President Obama's administration continues to deport larger numbers of immigrants than any other president before, including his Republican predecessor George W. Bush. ${ }^{108}$ Some of the deportees have lived in this country as lawful permanent residents for decades, including since childhood, but are nonetheless removed for minor criminal transgressions. ${ }^{109}$ Even so, among Latinos party affiliation with the Democratic Party continues to increase since President Obama's 2008 election. ${ }^{110}$ The final 2012 presidential election numbers show that Latinos ensured re-election victories for President Obama in battleground states, such as Colorado, Florida, Nevada, North Carolina, Ohio, Virginia, and Wisconsin. ${ }^{\prime \prime \prime}$

As the facts show, the media coverage of the 2008 Democratic Primary race is a perfect example of a divide-and-conquer strategy that could have divided African Americans and Latinos politically along racial lines in the

${ }^{106}$ Jessica Avila, Barack Obama Will Win the Latino Vote in 2012, Pol.ICYMic (Feb. 17, 2012), http://www.policymic.com/articles/4391/barack-obama-will-win-the-latino-vote-in2012. Although he did not introduce comprehensive immigration reform, on June 15, 2012, President Obama announced a change in administrative policy granting deferred action to "DREAMers"- undocumented immigrants who entered the United States as children. Julia Preston \& John H. Cushman Jr., Obama to Permit Young Migrants to Remain in U.S., N.Y. Timis (June 15, 2012), http://www.nytimes.com/2012/06/16/us/us-to-stop-deporting-some-illegal-immigrants.html. Republicans claimed that the timing of this change in policy was politically motivated in light of the upcoming presidential election. Tom Cohen, Obama Administration to Stop Deporting Some Young Illegal Immigrants, CNN Pol.rTics (June 16, 2012, 1:17 PM), http://www.cnn.com/2012/06/15/politics/immigration/index.html. Arizona Governor Jan Brewer called President Obama's immigration policy change a " "pre-emptive strike" aimed at an upcoming U.S. Supreme Court ruling [referring to the Court's pending ruling on the constitutionality of provisions of Arizona's immigration enforcement law] that could uphold parts of the state's immigration enforcement law." Gov. Brewer Responds to Obama's 'Outrageous' Immigration Policy Change, AZFAMILY (June 15, 2012, 12:30 PM), http://www .azfamily.com/video/raw/RAW-Gov-Brewer-responds-to-Obamas-outrageous-immigrationpolicy-change- $159226365 \mathrm{html}$. Ultimately, even if politics were involved, President Obama's executive decision was "one small step in the direction of humane immigration reform." Maritza Reyes, DREAMers Keep on Dreaming!, The Studen' Appeal. (June 21, 2012, 8:50 AM), http://thestudentappeal.com/op-ed/dreamers [hereinafter Reyes, DREAMers Keep on Dreaming!]

${ }^{107}$ Ana Gonzalez-Barrera, Mark Hugo Lopez \& Seth Motel, As Deportations Rise to Re cord Levels, Most Latinos Oppose Obama's Policy, Pew Hispanic Cianter 8 (Dec. 28, 2011), http://www.pewhispanic.org/files/2011/12/Deportations-and-Latinos.pdf.

${ }^{108} I d$. at 5 . Most of the individuals currently targeted for deportation come from Mexico and Central America. Maritza I. Reyes, Constitutionalizing Immigration Law: The Vital Role of Judicial Discretion in the Removal of Lawful Permanent Residents, 84 TEMr. L. Rev. 637, 681-82 (2012) [hereinafter Reyes, Constitutionalizing Immigration Law].

${ }^{109} \mathrm{Id}$. at $643-48$

${ }^{110}$ Gonzalez-Barrera, Lopez \& Motel, supra note 107, at 8. According to a Pew Hispanic Survey conducted in $2011,67 \%$ of Hispanic registered voters show allegiance to the Democratic Party and $20 \%$ to the Republican Party. Id. at 29-30.

"II Mark H. Lopez and Paul Taylor, Latino Voters in the 2012 Election, PewResenrCH Hispanic Trends Projecr (Nov. 7, 2012), http://www.pewhispanic.org/2012/11/07//atino-vot ers-in-the-2012-election/; Lee, supra note 16. 
general election. ${ }^{112}$ Although reporters may have over-stated the role that race played in the Clinton-Obama contest, they brought to light, on a national level, the elephant in the room-race. As the African-American and Latino communities continue to grow, it becomes even more important to analyze whether and how their distinct racial identities affect inter-group relations. ${ }^{113}$

\section{The Elephant in the Room: Race}

The African American and Latino experiences with race in this country are in need of continued exploration, but it is not the aspiration of this Article to provide a comprehensive analysis of these evolving realities. ${ }^{114}$

${ }^{112}$ See Goméz, supra note 4, at 456. More recently, the Zimmerman trial and verdict had the potential to divide African Americans and Hispanics because George Zimmerman is Latino through his maternal ancestry line and Trayvon Martin was Black. See, e.g., Paul A. Reyes, For Many of Us, Zimmerman Trial is About Race, NBCLATINo (July 15, 2013, 6:33 PM), http:/ /nbclatino.com/2013/07/15/opinion-for-many-of-us-zimmerman-trial-is-about-race/. Many Latinos joined with African Americans in voicing their outrage after the jury verdict that acquitted Zimmerman. See, e.g., NYC Democrats Call for DOJ Investigation of George Zimmerman, Talk Radio News Service (July 15, 2013), http://www.talkradionews.com/us/newyork/ $2013 / 07 / 15 /$ nyc-dems-call-for-doj-investigation-george-zimmerman.html. Hopefully, one individual's actions and the perceived motives for his choices will not be imputed to the entire Latino community. But see infra note 196 and accompanying text.

113 "The perspectives of Latinos and African Americans can shed light on racism that is hidden by long-term societal practices giving rise to post-racial ideologies." McKanders, Black and Brown Coalition Building, supra note 100, at 497.

The fact is that we scholars know far less than we should about whether, in the larger context beyond electoral behavior, there is a meaningful divide between Latinos and African Americans. The literature on the topic is surprisingly sparse, especially given the fact that Latinos and African Americans have lived in close proximity in many cities for generations (Los Angeles and Cook counties among them). At least in part, I think this stems from reluctance on the part of generally liberal researchers to ask questions about race that they might not want to hear the answers to. For some in the liberal academy, we would rather assume a different kind of conventional wisdom that emphasizes a black-brown coalition.

Yet those of us who would hope for a flourishing black-brown coalition do ourselves no favor by avoiding the subject. We need to begin asking the questions, and we need to do so with specificity, taking into account the many important differences among Latinos and African Americans (who themselves have substantial divisions according to nativity and ethnicity that are too often ignored by the media). We also need to provide an historical context for the inquiry about black-brown relations.

Gómez, supra note 4 , at 454.

${ }^{114}$ This Article recognizes that the history of African Americans in the United States has been documented more adequately than the history of Latinos in the United States. See JUAN F. Perea, Richard Delgado, Angela P. Harris, Jean Stefancic \& Stephanie M. Wilddman, Race and Races Cases and Resources for a Diverse America 285 (2d ed. 2007). In light of this recognition, the historical analysis of Latinos in this Article is more in depth as a way to educate and document a history that has often been ignored. See generally Juan F. Perea, Los Olvidados: On the Making of Invisible People, 70 N.Y.U. L. REv. 965 (1995). Some Latino scholars perceive that Latino scholars are more informed about the history of oppression against African Americans than Black scholars are aware of the history of oppression against Latinos. See, e.g., Geiza Vargas-Vargas, The Investment Opportunity in Mass Incarceration: A 
Rather, race is discussed in this Article because race influences politics and the political input of individuals and groups; and these together affect immigration law and policy. In turn, "[i]mmigration law offers a helpful gauge for measuring this nation's racial sensibilities." 115 Therefore, a dialogue about the immigration debate must consider all relevant issues in recognition that "the sound exercise of national power over immigration depends on the Nation's meeting its responsibility to base its laws on a political will informed by searching, thoughtful, rational civic discourse."116

A discussion about race in the United States cannot obviate the obvious-race permeates individual and group interactions, ${ }^{117}$ and the failure to address race and racism in an open and educated manner delays the accomplishment of Dr. Martin Luther King Jr.'s dream of a united race of Americans. ${ }^{118}$ The politics that drive the current immigration debate continue to hide racist motives. ${ }^{19}$ Racism has been defined by some as "the active practice of using the race paradigm to reinforce hierarchy, subordination, and trauma." 120 African Americans and Latinos are victims of racism. ${ }^{121}$ Latinos will not become fully integrated into the fabric of U.S. society until "problems associated with racism and discrimination [are] addressed and alleviated." 122 This admonition has been thoroughly argued by African Americans in relation to the struggle of Blacks to become fully integrated into American society. ${ }^{123}$ Regrettably, victims of racism sometimes become victimizers or participate in their own victimization. ${ }^{124}$ However, there is

Black (Corrections) or Brown (Immigration) Play?, 48 CAL. W. L. Rev. 351, 367 (2012) ("For blacks, mostly the black experience matters. Hence, the light treatment if any on the impact of immigration on mass incarceration."). The author of this Article shares this perception and has made efforts to inform African-American colleagues about the historical and ongoing Latino experiences in the United States, including with regard to immigration. This Article is a further effort in this endeavor.

115 Kevin R. Johnson, Race, the Immigration Laws, and Domestic Race Relations: A "Magic Mirror" into the Heart of Darkness, 73 IND. L.J. 1111 , 1148 (1998) [hereinafter Johnson, Race, the Immigration Laws, and Domestic Race Relations].

116 Arizona v. United States, 132 S. Ct. 2492, 2510 (2012).

${ }^{117}$ lan F. Haney Lopez, The Social Construction of Race: Some Observations on Illusion, Fabrication, and Choice, 29 HARv. C.R.-C.L. L. REv. 1, 3, 9, 18 (1994) [hereinafter Lopez, The Social Construction of Race].

${ }^{118}$ Reyes, A Latina Law Professor's Personal Perspective, supra note 36.

${ }^{119}$ Karla Mari McKanders, Sustaining Tiered Personhood: Jim Crow and Anti-Immigrant Laws, 26 HaRv. J. RACIAL \& ETHNiC JUST. 163, $185-87$ (2010) [hereinafter McKanders, Personhood].

${ }^{120}$ See, e.g., E. Christi Cunningham, Exit Strategy for the Race Paradigm, 50 How. L.J. 755,783 (2007). The author of this Article would propose a broader definition of racism that includes exclusion; rejection; and negative views, beliefs, perceptions, assumptions, actions, omissions, and attitudes toward individuals and groups that are based, consciously or unconsciously, on a person's perceived racial/ethnic identity.

${ }^{121}$ Johnson, Latinas/os and the Political Process, supra note 48, at 935.

122 Rodríguez, Sáenz \& Menjívar, supra note 80, at xvi.

${ }^{123}$ See, e.g., W.E.B. Du Bois, The SOUls of BLACK Fol.K (2003) (first published in 1903); Derrick Bell, Ani We Are Not Saved: The Elusive Quest for Racial Justice (1987); Carl. T. Rowan, The Coming Race War in America: A Wake-up Call (1996); Charlees J. Ogletree, JR., The Presumption of Guilt (2010).

${ }^{124}$ Cf. Pamela J. Smith, Looking Beyond Traditional Educational Paradigms: When Old Victims Become New Victimizers, 23 Hambine L. Rev. 101, 106-76 (1999) (positing that some 
trepidation about even considering whether people of color can be racist against other people of color. ${ }^{125}$ This apprehension was exhibited in discussions surrounding the Zimmerman case when claims of racial profiling were often silenced by the response that George Zimmerman, the man who followed and killed Trayvon Martin, a Black teenager, is Hispanic. ${ }^{126}$

If we are honest, ${ }^{127}$ there is no question that some Latinos hold racist, anti-Black sentiment ${ }^{128}$ and some Blacks hold racist, anti-Latino sentiment. ${ }^{129}$ As African-American author Earl Ofari Hutchinson explains it in his book The Latino Challenge to Black America, "[t]he dirty and painful secret is that blacks and Latinos can be as racist toward each other as some whites can be toward them."130 And, as documented by Latino author Nicolás C. Vaca in his book Presumed Alliance: The Unspoken Conflict Between Latinos and Blacks and What it Means for America, racial animosity between the groups has foreclosed power sharing even when one group has seized political representation with the help of the other. ${ }^{131}$ Professor Harlon $\mathbf{L}$.

White women who were victimized because of their gender in turn victimize White girls and Black children, especially Black boys, in the education system); see also César Cuauhtémoc García Hernández, La Migra in the Mirror: Immigration Enforcement, Racial Profiling, and the Psychology of One Mexican Chasing Another, 72 ALB. L. Rev. 891, 891 (2009) [hereinafter García Hernández, La Migra in the Mirror] (arguing that reliance by U.S. Border Patrol on American agents of Mexican ancestry to enforce race-based immigration policing to identify Mexican immigrants is destructive to the enforcers, the targets, and their communities along the border).

125 Perea, Delgado, Harris, Stefancic \& Wildman, supra note 114, at 46-47.

${ }^{126}$ Raul A. Reyes, Opinion: For Many of Us, Zimmerman Trial is About Race, NBCLATINO (July 15, 2013, 6:33 PM), http://nbclatino.com/2013/07/15/opinion-for-many-of-us-zimmerman-trial-is-about-race/ [hereinafter Reyes, Zimmerman Trial]. Zimmerman was initially described as White and was later described as "White Hispanic" because his father is White and his mother is Latina. Eric Wemple, Why Did New York Times Call George Zimmerman 'White Hispanic'?, WASH. Posr (Mar. 3, 2012, 1:52 PM), http://www.washingtonpost.com/ blogs/erik-wemple/post/why-did-new-york-times-call-george-zimmerman-white-hispanic/

2012/03/28/gIQAW6fngS_blog.html. The concept of "White Latinos" was examined in an article by Professor Ian Haney López in 2003. Ian Haney López, White Latinos, 6 Harv. LATino L. Rev. 1 (2003) [hereinafter López, White Latinos].

127 "Integrity is telling myself the truth. And honesty is telling the truth to other people." 16 Guidelines for Life-CHonesty, http://www.16guidelines.org/how-we-act/honesty (last visited Mar. 15, 2014) (quoting Spencer Johnson). "Almost any difficulty will move in the face of honesty. When I am honest I never feel stupid. And when I am honest I am automatically humble." Id. (quoting Hugh Prather). "To make your children capable of honesty is the beginning of education." Id. (quoting John Ruskin). "We tell lies when we are afraid ... afraid of what we don't know, afraid of what others will think, afraid of what will be found out about us. But every time we tell a lie, the thing that we fear grows stronger." Id. (quoting Tad Williams). "If you tell the truth you don't have to remember anything." Id. (quoting Mark Twain).

${ }^{128}$ Tanya Kateri Hernández, Latino Inter-Ethnic Employment Discrimination and the "Diversity" Defense, 42 HaRv. C.R.-C.L. L. Rev. 259, 267-75 (2007) [hereinafter Hernández, "Diversity" Defense]; Kevin R. Johnson, The Struggle for Civil Rights: The Need for, and Impediments to, Political Coalitions Among and Within Minority Groups, 63 LA. L. Rev. 759, 777 (2003) [hereinafter Johnson, The Struggle for Civil Rights].

${ }_{129}$ Johnson, The Struggle for Civil Rights, supra note 128, at 777.

130 Eari. Ofari Hutchinson, The Latino Challenge to Black America 63-64 (2007).

131 See generally Nicolás C. Vaca, The Presumed Alliance: The Unspoken Conflict Between Latinos and Blaacks and What it Means for America (2004). 
Dalton stated, succinctly yet eloquently, how we should approach conversations about inter-group racism:

It is critically important for Black folks to own up to these sentiments and to question our assumptions and beliefs about other communities of color. It is also important for Latinos, Asian Americans, and Native Americans to encourage us around these issues and to put their own stuff on the table as well. If we do not explore the real differences that exist among us, we will never discover what we truly have in common. We cannot in good conscience insist that White folk take up the cause of racial justice if we are not equally willing to struggle with the issues of pecking order and bias among ourselves. ${ }^{132}$

\section{Professor Kevin Johnson suggested that in order to move forward:}

[W]e must begin to address racism within minority communities directed at other communities of color if we hope to build coalitions among those communities. Unfortunately, racism among minority communities is a social problem that thwarts collective action. Rather than condemn yet ignore it, those committed to social justice must acknowledge the problem and struggle with its solution. In the long run, this likely will prove to be a formidable challenge to the struggle for civil rights. ${ }^{133}$

Initially, it is important for African Americans and Latinos to recognize that the two communities' understanding of race is complicated by the different historical development of race during the English and Spanish colonial systems. ${ }^{134}$ The conquest of America by the Spanish ${ }^{135}$ caused a racial mix-

132 Harlon L. Dalton, Racial. Healing 206-10, 223-34 (1995), reprinted in Perea, Deigado, Harris, Strifancic \& Wildman, supra note 114, at 1231-35.

${ }^{133}$ Johnson, The Struggle for Civil Rights, supra note 128, at 783.

${ }^{134}$ GoNZALEZ, supra note 83, at 184 . For West Indians, the concept of race is also different from the African American understanding of race. See Kamille Wolff, Out of Many, One People; E Pluribus Unum: An Analysis of Self-Identity in the Context of Race, Ethnicity, and Culture, 18 Am. U. J. Gendoer Soc. Pol'Y \& L. 747, 752-53 (2010). This Article does not promote a romantic notion of peaceful conquest of indigenous people in Spanish America. The conquest was violent and treacherous. See, e.g., MAtrthew Restall \& Kris LAne, LAtin AmErica in COLONIAl. Times 85-97 (2011) (documenting historical acts of treachery by the Spanish conquerors, including the deceitful killing of Mexica emperor Xocoyotl Moctezuma). Some historians argue that the real story of the conquest has not been told. See Jaime Wheelock Román, Raíces Indígenas de la Lucha Anticolonialista en Nicaragua de Gil González a Joaquín Zavala (1523 a 1881) [Indigenous Roots of the Anticolonialist Fight in Nicaragua from Gil González to Joaquín Zavala (1523 to 1881)] 1-13 (4th ed. 1980) (criticizing historians for taking the side of the colonizers and under-reporting the atrocities committed by the Spanish conquerors against the indigenous people).

${ }^{135}$ Some authors analyze the Brazilian experience with race as part of the overall Latin American experience. See, e.g., Hernádez, Racial Subordination, supra note 41, at 173. However, it is relevant to distinguish that Brazil was conquered by the Portuguese, the Portuguese dominated slave trade in the Americas from 1492 to 1640 (followed by the English from 1640 to the nineteenth century), the Portuguese enslaved indigenous people more than any other European colonizers, Portuguese Brazil received the highest number of African slaves 
ing from its inception that was different from the racial mixing of the British conquerors and settlers north of the Rio Grande. ${ }^{136}$ The Spanish conquistadors and settlers engaged in more liberal sexual exchanges that led to the "development of miscegenation between different racial stocks, such as the Indo-American, the European, and the African." 137 At the beginning of the Spanish conquest, miscegenation was encouraged. ${ }^{138}$ In the early years of the Spanish conquest, most African slaves were men. ${ }^{139}$ Because of the lack of African women and the ready access to indigenous communities that the Spanish fostered, African slaves found partners among the indigenous women. ${ }^{140}$ Similarly, only a small number of women accompanied the Spanish conquistadors; consequently, some of them established families with indigenous women. ${ }^{141}$ In contrast, as the Dred Scott $v$. Sanford ${ }^{142}$ decision details, the North American colonies and later the states went to great lengths to maintain the purity of the White race and to deter open miscegenation. ${ }^{143}$

Another significant difference in the development of a racial identity in what is now Latin America was the acculturation that accompanied the racial mixing; indigenous people (natives), Africans, and the racially mixed Latin Americans acquired Spanish culture, but the racial mixing also re-defined Spanish culture to include the various cultures that were involved in the racial mixing. ${ }^{144}$ For example, during the conquest, one Spanish group adopted an indigenous (Quechua) cultural identity. ${ }^{145}$ In Paraguay, where the Spaniards were outnumbered by the Guaraní, the Spaniards were absorbed into the Guaraní group through intermarriage and even adopted the Guaraní language. ${ }^{146}$ The group's culture in turn developed into a complex Guaraní Catholic culture. ${ }^{147}$ This process of acculturation and integration did not occur in a similar way in colonial Anglo-America where there was a

(4.2 million) of any individual region in the American continent, and Brazil was one of the last countries in the American continent to grant freedom to slaves (in the 1850s). Restrall \& LANE, supra note 134, at 153-55, 157. "In contrast to most of Spanish America, Brazil became a slave society in the late sixteenth century and remained such for three centuries." $I d$. at 155. Therefore, the Brazilian experience with race and with slavery is different in significant aspects from the experience in Latin American countries colonized by the Spanish.

136 Cl.audio Esteva-Fabregat (Translatej) by John Wheat), Mestisaje [RacialMixing] in IBERo-America 43 (1995).

${ }_{137}$ Id.

${ }^{138}$ Problems in Modern Latin American History: Sources and Interpretations 4 (John Charles Chasteen \& James A. Wood eds., 2005). at 4 .

${ }^{139}$ Restall \& LaNe, supra note 134, at 158. Accord Chasteen \& Wood, supra note 138,

${ }^{140}$ Rest'AlL \& LANE, supra note 134, at 158. Accord Chasteen \& Wood, supra note 138, at 5 .

${ }^{141}$ ReSTAll \& LANE, supra note 134 , at 102, 113. Accord Chasteen \& Wood, supra note 138 , at 4.

${ }^{142} 60$ U.S. 393 (1856).

${ }^{143} \mathrm{Id}$. at 413 .

${ }^{144}$ Esteva-FABREGAT, supra note 136 , at 46-49.

${ }^{145}$ Id. at 49.

${ }^{146}$ Restall \& LANE, supra note 134 , at 145.

${ }^{147} \mathrm{Id}$. 
more rigid division between the master's culture and slave culture. ${ }^{148}$ The Spanish established their cities in close proximity to indigenous villages. ${ }^{149}$ Europeans in Anglo America sought to remove Native Americans from their ancestral lands and thereby separated from them geographically. ${ }^{150}$

Because "[m]odern concepts of race did not exist until the very end of the [Spanish] colonial period," 151 the Spanish initially distinguished people by types (géneros) and "used notions of ethnicity and class to create two related socioracial concepts." 152 Under this semi-fluid system of identification, Spanish were at the top, followed by mestizos ${ }^{153}$ and indigenous people, followed by "free coloreds," and followed by Africans at the bottom. ${ }^{154}$ However, politically and economically, Afro-descendants were able to rise to a level above natives through militia service, "passing" as Spaniards, and serving as intermediaries between the Spanish and the indigenous community leaders. ${ }^{155}$ Sebastián Toral, a former African slave, became a Spanish conquistador. ${ }^{156}$ Slaves had greater access to freedom through self-purchase or purchase of family members in the Spanish territories than in the British colonies. ${ }^{157}$ Mixed-race individuals of Spanish and African ancestry could

148 Alan Brinki.ey, Richard N. Current, Frank Freidel. \& T. Harry Willianms, American History A Survey Volume I: ro 1877335 (8th ed. 1991).

${ }^{149}$ Restald. \& LANe, supra note 134, at 134-35.

${ }^{150}$ Ann Picard, Death by Boarding School: "The Last Acceptable Racism" and the United States' Genocide of Native Americans, 49 GoNz. L. REv. 137, 142-50 (2013-2014).

${ }^{151}$ Restall. \& LANE, supra note 134, at 204.

${ }^{152}$ Id.

153 In some historical accounts, the term mestizo (a Spanish word meaning mixed) describes people of European and indigenous ancestry in Spanish America. Chasteen \& Wood, supra note 138 , at 1 . But some historians give a broader definition to the term to include people of mixed Spanish, indigenous, and Black ancestry "on a cultural and genetic level." ESTEVA-FABREGAT, supra note 136, at 20. A more accurate definition of the term would include all race-mixing. See Kif Augustine-Adams, Marriage and Mestisaje, Chinese and Mexican Constitutional Interpretation and Resistance in Sonora, 1921-1935, 29 LAw \& Hist. Rrv. $419,426-28$ (2011) (describing mixing of Mexicans and Chinese in Mexico beginning in the $1800 \mathrm{~s})$.

${ }^{154}$ Restall \& LANE, supra note 134 , at 205.

${ }^{155} \mathrm{Id}$.

${ }^{156}$ Id. at 100 .

${ }^{157}$ Id. at 156 . The first official record of the birth of a Black child in what is now the United States was documented in St. Augustine, Florida, in 1606, more than a decade before African slaves arrived in Jamestown, Virginia in 1619. First Black Birth Recorded in America, AFRICAN AMERICAN REGISTRY, http://www.aaregistry.org/historic_events/view/first-blackbirth-recorded-america (last visited Mar. 12, 2014). In the sixteenth century, Spanish explorers founded St. Augustine, decades before any other European settlement in North America. Craig Manson, Black Catholic History Month: Preserving St Augustine's Documents, GENEABlocile (Nov. 24, 2009, 9:02 PM), http://blog.geneablogie.net/2009/1 1/black-catholichistory-month-preserving-st-augustines-documents/. Thus, the history of African Americans in Florida began under Spanish Catholicism. Id. Later, "[t]he Spanish provided sanctuary for slaves who escaped from the British colonies in North America. The first such area of sanctuary was in St. Augustine in 1738, known as Fort Mose." Id. Today, Fort Mose is a state park remembered as "the site of the first legally sanctioned free African settlement in what is now the United States." Fort Mose Historic State Park, Florima State Parks, http://www .floridastateparks.org/fortmose/ (last visited Feb. 11, 2014). The Fort was founded in 1738 by the Spanish governor of Florida. Id. The fort's full name, Gracia Real de Santa Teresa de Mose, was shortened to Fort Mose. Id. It was the first settlement for Black slaves "fleeing 
purchase certificates declaring them "legally white," which allowed them "to hold office, seek an education, and enjoy other privileges usually reserved for those at the top of the social hierarchy." 158 In contrast, Whites in Anglo America developed the "one-drop rule," which meant that even mixed-race Blacks of White ancestry could not gain freedom or privileges reserved for pure Whites. ${ }^{159}$ Slavery was abolished in many Latin American countries soon after they gained independence from Spain. ${ }^{160}$ It took a Civil War almost a century after the American Revolution began to abolish slavery in the United States. ${ }^{161}$

The racial mixing during the Spanish period, if it had remained as it started, would have resulted in a majority mestizo population throughout Latin America. ${ }^{162}$ However, subsequent migrations of Europeans, who were not willing to engage in racial mixing, and deliberate immigration "whitening" policies developed more White populations in some countries in Latin America. ${ }^{163}$ This led to racism that is more prevalent today in some countries than in others. ${ }^{164}$ Additionally, as with the people of many (if not all)

slavery from the English colonies in the Carolinas. Over the next 25 years, Fort Mose and Spanish Saint Augustine became a sanctuary for Africans seeking liberation from the tyranny of English slavery." Id.

${ }^{158}$ Chasteen \& Wood, supra note 138, at 11 (citing report issued by the City Council of Caracas in 1796 and directed to the king of Spain whereby the colonial elite protested a provision enacted by the Spanish Crown granting "legally white" status to mixed-race Blacks).

${ }^{159}$ Amos N. Jones, Black Like Obama: What the Junior Illinois Senator's Appearance on the National Scene Reveals About Race in America, and Where We Should Go From Here, 31 T. Marshall L. Rev. 79, 86 (2005).

${ }_{160}$ Juliet Hooker, Afro-descendant Struggles for Collective Rights in Latin America: Between Race and Culture, Souls: A Critical Journal of Black Politics, Culture, and Society, 10:3, 279-291, 291 n.22 (2008), http://www.tandfonline.com/doi/abs/10.1080/1099994080234 7764\#.UestsKy7c5s.

${ }^{161}$ Slavery in the United States was envisioned to survive after independence from Britain; in fact, Whites in the South feared that the Revolutionary War would foment slave rebellions. Brinkley, Current, Freidel \& Williams, supra note 148, at 145 . In the early 1800 s, White southerners demanded the acquisition of Florida in part because slaves escaped from the United States into this Spanish territory where they could be free. Id. at 225. This was a motivation for the War of 1812 because Spain was allied with Britain and the war would give frontiersmen an excuse for taking Spanish territory. $I d$. The United States continued its acquisition of Spanish territories after declaring war against Spain in 1898. Ray SuArez, Latino Amiricans-The 500-Year Legacy That Shaped a NATion 57-60 (2013). As a result of that fairly quick and inexpensive conflict (as far as a war is concerned), the United States gained control over Cuba, Guam, the Philippines, and Puerto Rico. Id. at 60-61.

${ }^{162}$ Esteva-FABREGAT, supra note 136 , at 305.

${ }^{163}$ See id. (describing the migration of Germans to Brazil and Chile and their less favorable attitude toward racial mixing with Black and indigenous people). See also HerNÁNDEZ, RACIAL SUBORDINATION, supra note 41, at 23-26 (describing immigration policy in Argentina that was designed to Europeanize (whiten) the country's population).

${ }^{164}$ Hernádez, "Diversity" Defense, supra note 128, at 267-75. 
countries around the world, ${ }^{165}$ the people of many nations in Latin America have been influenced by colorism: ${ }^{166}$ the preference for "whiteness." 167

Once in the United States, immigrants from Latin American countries and their descendants may reinforce or learn racist ways. ${ }^{168}$ Today, some Latinos are still trying to comprehend race as it is understood in the United States and where they fit within the U.S. racial structure. ${ }^{169}$ Racism, including intra-Latino racism, ${ }^{170}$ is generally tied to national origin and often related to the particular group's or individual's claim to whiteness--European ancestry. ${ }^{771}$ Within the Latin American hierarchy of race, countries that can lay claim to more pure European roots "are viewed as more advanced than those more significantly populated with people of indigenous descent or those of African descent." 172 In some countries in Latin America, segments of the population who view themselves as White discriminate against Latin

${ }^{165}$ Angela P. Harris, From Color Line to Color Chart?: Racism and Colorism in the New Century, 10 Berkeley J. AFr.-Am. L. \& Pol'y 52, $55-56$ (2008) [hereinafter Harris, Racism and Colorism] ("There is ample evidence, for example, that light skins are also preferred to dark ones in East and South Asia, regions where African slavery had little or no presence and where the valuation of light skin predates the slave trade.") (citing Jyotsna Vaid, Fair Enough? Color and the Commodification of Self in Indian Matrimonials, in SHAdres or DifFerence (Evelyn Nakano Glenn ed., 2008)).

166 "Traditional racism places a higher value on ancestry than colorism; traditional racism assigns people to discrete racial categories, while colorism assigns people to places along a spectrum from dark to light, indigenous or African to European." Harris, Racism and Colorism, supra note 165 , at 61 . Colorism is also present in the African-American community. Taunya Lovell Banks, Colorism: A Darker Shade of Pale, 47 U.C.L.A. L. Rrv. 1705, 1713-24 (2000).

${ }^{167}$ Hernádez, "Diversity" Defense, supra note 128, at 259, 267-75. In the Dominican Republic, although $90 \%$ of the population can trace its ancestry to African roots, there is a concerted effort by Dominicans to distance themselves from an association with "blackness," and, as a result, lighter skin and straight hair are favored. Richard T. Middleton \& Sheridan Wigginton, A Comparative Analysis of How the Framing of the Jus Soli Doctrine Affects Immigrant Inclusion into a National Identity, 21 Temp. Pol. \& CIv. RTs. L. REv. 521, 529 (2012).

${ }^{168}$ Hernádez, "Diversity" Defense, supra note 128, at 267-81. Studies of inter-group attitudes between Latinos and Blacks show that Blacks view Latinos more favorably than Latinos view Blacks. Shayla C. Nunnally, Trust in Black America 204 (2012) (citations omitted). In order to avoid what this Article decries-a failure to analyze the real impact of race on interpersonal and group relations-more studies need to evaluate the underlying reasons for the attitude discrepancy between the two groups.

${ }^{169}$ Elaine Ayala \& Ellen Huet, Hispanic May Be a Race on 2020 Census, SAn FranCisco GATE (Feb. 4, 2013), http://www.sfgate.com/bayarea/article/Hispanic-may-be-a-race-on-2020census-4250866.php.

${ }^{170}$ See, e.g., Cuello Suarez v. Puerto Rico Elec. Power Auth., 798 F. Supp. 876 (D. P.R. 1992) (analyzing claim that Puerto Rican employer discriminated against employee from the Dominican Republic); Cardona v. American Express Travel Related Servs. Co., Inc., 720 F. Supp. 960 (S.D. Fla. 1989) (finding that a Colombian employee could assert claim of race discrimination based on allegations that he was passed over for promotions by Cuban managers who favored Cuban employees).

${ }^{171}$ Hernádez, "Diversity" Defense, supra note 128, at 259, 298. See also Cuello Suarez, 798 F. Supp. at 890-91 (explaining that some Puerto Ricans associate Dominican national origin with non-White racial origin).

${ }^{172}$ Hernádez, "Diversity" Defense, supra note 128, at 259, 298 (citations omitted) ("Latin American racial constructs would rank Argentina as a highly valued White country."). 
Americans who are not considered to be White. ${ }^{173}$ In the United States, the major Spanish-language television networks have been criticized for the obvious preference for White-looking Hispanics. ${ }^{174}$ So yes, there is evidence that some Latinos hold racist views, including against other Latinos. ${ }^{175}$ In an opinion piece about the Zimmerman case, attorney Raul A. Reyes put it this way: "[J]ust because Zimmerman is Hispanic does not mean he was not racist. Latinos are just as capable of racism as anyone else." ${ }^{176}$ In 2007, Professor Tanya K. Hernandez wrote in the L.A. Times that racial hatred was causing Latino gangs to violently attack African Americans in Los Angeles. ${ }^{177}$ In 2010, she also wrote about "Black-on-Mexican Violence" in Staten Island, New York. ${ }^{178}$ In Asuza, California, members of a violent Latino gang perpetrated hate crimes against Blacks for nearly two decades. ${ }^{179}$

African Americans have reason to be apprehensive about immigrants who may start as people of color in the United States and later try to switch to a White identity. ${ }^{180}$ This was the path of Jews, Italians, and Irish. ${ }^{181}$ Mexi-

${ }^{173}$ See, e.g., Middleton \& Wigginton, supra note 167, at 538-39 (describing Chileans who view themselves as White and discriminate against non-White Peruvian and Bolivian immigrants).

${ }_{174}$ Michael A. Fletcher, Racial Bias Charged on Spanish-language TV, SUN SENTINEI. (Aug. 6, 2000), http://articles.sun-sentinel.com/2000-08-06/news/0008060066_1_spanish-latino-leaders-caste.

${ }^{175}$ Hernádez, "Diversity" Defense, supra note 128, at 270-71. More research should investigate intra-Latino relations. See Rodríguez, Sáenz \& Menjívar, supra note 80, at 6 . The Latino community in the United States seldom addresses the intra-Latino conflicts, which are often based on national origin. Anecdotally, most Latinos would acknowledge that, when Latinos meet each other, one of the first questions asked relates to Latin American national origin, even if the person was born in the United States. One of the challenges, as the Latino community continues to evolve in the United States, will be a much needed conversation as to whether Latinos want to continue dividing themselves along national origin lines or whether they will embrace a common U.S. Latino identity based on the shared experiences and the racial categorization that Latinos encounter in the United States. This is a question currently being considered by the U.S. Census. Sanda Lilley, Census Might Make "Hispanic" a Race, NBCLATiNo (Jan. 4, 2013, 5:20 PM), http://nbclatino.com/2013/01/04/census-might-make-his panic-a-racel.

${ }^{176}$ Reyes, Zimmerman Trial, supra note 126.

${ }^{177}$ Tanya K. Hernandez, Roots of Latino/Black Anger, L.A. Times (Jan. 7, 2007), http:// www.latimes.com/news/la-op-hernandez7jan07,0,170115.story.

${ }_{178}$ Tanya Katerí Hernández, Black-on-Mexican Violence in Staten Island, NY: The Untold Tale of Turf Defense, Hispanic IsTA (Aug. 24, 2010), hitp://www.hispanicvista.com/HVCI Columnist/HVC/Opinion/Guest_Columns/091010_Tanya_Kateri_Hernandez.htm.

${ }^{179}$ Ruby Gonzales \& Melissa Masatani, Azusa Gang Leader Gets Nearly 20 Years for Hate Crimes Against Blacks, Pasadena Star-News (Jan. 14, 2013), hup://www.pasadenastarnews.com/general-news/201301 15/azusa-gang-leader-gets-nearly-20-years-for-hate-crimesagainst-blacks.

${ }^{180}$ Even Latinos who may not appear White to others may self-identify as White because they were considered White in their country of origin. Mireya Navarro, For Many Latinos, Racial Identity Is More Culture Than Color, N.Y. Times (Jan. 13, 2012), http://www.nytimes .com/2012/01/14/us/for-many-latinos-race-is-more-culture-than-color.html?_r=1\&emc=etal (reporting on New York lawyer who self-identified as White in the $2010 \mathrm{U} . \overline{\mathrm{S}}$. Census because she is light-skinned and, as such, would be considered White in the Dominican Republic).

${ }^{181}$ See Richard Delgado, Linking Arms: Recent Books on Interracial Coalition as an Avenue of Social Reform, 88 CoRnel.L. L. REv. 855, 882-84 (2003) [hereinafter Delgado, Linking Arms]. 
cans initially pursued a White assimilation strategy, ${ }^{182}$ but were unsuccessful. ${ }^{183}$ Many Cubans today identify themselves as White. ${ }^{184}$ And mixed-race Latinos with a White parent also add to the complexity of the racial identification. ${ }^{185}$ The fear of some African Americans is that Latinos who assimilate into whiteness will also assimilate into some of the privileges associated with whiteness, including racism against Blacks. ${ }^{186}$ This was the issue in the minds of many after George Zimmerman killed Trayvon Martin. ${ }^{187}$

Although some scholars argue that Blacks cannot be racist in relation to Whites because Blacks did not create institutionalized racism, ${ }^{188}$ African Americans may also be racist, ${ }^{189}$ including against other Blacks. ${ }^{190}$ In Weath-

${ }^{182}$ Neil Foley, Over the Rainbow: Hernandez v. Texas, Brown v. Board of Education, and Black v. Brown, 25 Chicano-Latino L. Rev. 139, 140 (2005).

${ }^{183}$ Mexican-Americans were legally constructed as White in the court system, but did not get treated as equal to Whites; they remained segregated as a separate and inferior race. George A. Martínez, African-Americans, Latinos and the Construction of Race: Toward an Epistemic Coalition, 19 Chicano-Latino L. Rev, 213, 219-20 (1998).

${ }^{184}$ Rodríguez, Sáenz \& Menjívar, supra note 80, at xvi.

${ }^{185}$ Navarro, supra note 180.

186 Taunya Lovell Banks, Mestizaje and the Mexican Mestizo Self: No Hay Sangre Negra, So There Is No Blackness, 15 CAL. IN'TERDISC. L.J. 199, 233, 202 n.18 (2006) (citations omitted). An in-depth analysis of the claim that Latinos will become White (and engage in the racism associated with whiteness) over time is beyond the scope of this Article, but it is important to acknowledge this argument. George Yancey advances this proposition in his book. Grorge Yancey, Who is White? Latinos, Asians, and the New Black/NonBlack DiVIDE 14-15 (2003).

${ }^{187}$ Reyes, Zimmerman trial, supra note 126. After the accusations of racism began, George Zimmerman's father delivered a letter to the Orlando Sentinel explaining that his son is Hispanic, of Peruvian heritage. Rene Stutzman, George Zimmerman's Father: My Son is Not Racist, Did Not Confront Trayvon Martin, ORL,Ando SenTinel (Mar. 15, 2012), http://articles .orlandosentinel.com/2012-03-15/news/os-trayvon-martin-shooting-zimmerman-letter-201203 15_1_robert-zimmerman-letter-unarmed-black-teenager. Zimmerman also has African ancestry on his mother's Peruvian side. Chris Francescani, George Zimmerman: Prelude to a Shooting, REuTERs (Apr. 25, 2012), http://www.reuters.com/article/2012/04/25/us-usa-floridashooting-zimmerman-idUSBRE83O18H20120425. These are current events in the evolving reality of the United States. As scholars with a voice, many of us are able to analyze these issues and educate ourselves and others as we push forward with the American experiment. Sometimes legal academics can provide a personal perspective that places in context, through our lived experiences, the social, legal, and political issues of our time. See, e.g., Reyes, $A$ Latina Law Professor's Personal Perspective, supra note 36; Angela Onwuachi-Willig, 'I wish I were Black' and Other Tales of Privilege, The Chronicle of Higher Education (Oct. 28, 2013), http://chronicle.com/article/I-Wish-I-Were-Black-and/142561/?cid=cr\&utm_source= cr\&utm_medium=en. As feminists recognized long ago, the personal is after all political. Angela P. Harris \& Carmen G. González, Introduction to Presumed Incompetent: The INtersections of Race and Class for Women in ACAdemia 4 (Gabriella Gutiérrez y Muhs, Yolanda Flores Niemann, Carmen G. González, and Angela P. Harris eds., 2012).

${ }^{188}$ See, e.g., Joe R. FeAgin \& HeRnán Vera, White RACISM ix-x (1995), reprinted in Perea, Delgado, Harris, Stefancic \& Wildman, supra note 114 , at 47.

189 See Michail. Omi \& Howard Winant, Racial. Formation in the Untred States 73, reprinted in Perea, Delcadoo, Hakris, Stgfancic \& Wildman, supra note 114, at 47 (stating that racial minorities have attained power and influence in recent years and can be racist towards Whites).

${ }^{190}$ See, e.g., Saleh v. Virginia State University, No. Civ.A. 3:97-CV-460 R, 1999 WL 34798179 , at *1 (1999) (examining claim by Black Nigerian professor who alleged that majority-Black university gave preferential treatment to native-born Black faculty). See also Angela M. Porter, Comment, Pharaohs, Nubians, and Antiquities: International Law Suggests It's 
erly v. Alabama State University, ${ }^{191}$ a jury found in favor of three AfricanAmerican women who alleged that African-American supervisors discriminated against them on the basis of race and sex in the workplace; the Eleventh Circuit affirmed the jury's award. ${ }^{192}$ As the United States becomes more diverse and members of minority groups are in positions to exert racially discriminatory power over other people of color, "discrimination among non-White racial and ethnic groups" rears its ugly head. ${ }^{193}$ The presence of Latinos, in localities where African Americans had been, until recently, the more visible minority presence, has caused violent "turf-wars" between the groups. ${ }^{194}$ The racial tensions and racism are not imagined. ${ }^{195}$ After the Zimmerman verdict, an eyewitness described how Black young men and young women chased, pistol-whipped, and kicked a Hispanic man in the streets of Baltimore, Maryland while repeatedly yelling: "This is for Trayvon, [expletive].", 196

During the riots after the Rodney King verdict in Los Angeles, Fidel López, a Guatemalan immigrant, became the target of a Black mob that slashed his forehead, nearly severed his ear, black spray-painted his genitals, and doused his body with gasoline. ${ }^{197}$ The attackers would have set him on fire but for the intervention of a Black preacher, Reverend Bennie Newton, who threw his body over Lopez's and drove him to a hospital. ${ }^{198}$ Latinos who saw this violent attack (the incident was broadcasted live by a media helicopter) by Blacks upon a stereotypically-looking Latino were incensed,

Time for a Change in Egypt, 56 How. L.J. 541, 574 n.285 (2013) ("[D]ifferent groups of black people can distinguish and detest one another, just as different groups of Europeans have done. Black people are of different cultures and complexions; they can go to war and they can unite."). Some scholars have used the term "tribalism" to describe a preference for those who are "similar or similarly situated." Thomas Earl Geu, Chaos, Complexity, and Coevolution: The Web of Law, Management Theory, and Law Related Services At the Millenium, 65 TenN. L. Rev. 925, 959 (1998) (citing John NaisbitT, Global Paradox: The Bigger The World Economy, the More Powerful Its Smallest Players 23 (1994)). The difference between tribalism and racism, if there is any, seems to be a question of semantics. As one author expressed it, "When does tribalism become racism? In the end it does not matter what one calls the issue." Duane Ruth-Heffelbower, Indonesia: Out of One, Many?, 26-FALL FLETCHER F. WORLD AFF. 223, 231 (2002).

191728 F.3d 1263 (11th Cir. 2013).

${ }^{192}$ Id. at 1274 .

${ }^{193}$ See Hernández, “Diversity” Defense, supra note 128, at 264.

194 McKanders, Black and Brown Coalition Building, supra note 100, at 491 (citing Tanya Hernández, Black-on-Mexican Violence in Staten Island, NAT' I INST. ON LATINo PoL'y (Aug. 25, 2010), http://ih.constantcontact.com/fs057/1 101040629095/img/345.jpg).

${ }^{195}$ See id. at 476 (detailing news reports of African-American young men targeting Mexican-American immigrants in Staten Island) (citing Kirk Semple, Young Residents on Staten Island Try to Make Sense of a Spate of Violence, N.Y. Times, Aug. 4, 2010, at A23); Tanya Hernández, Roots of Anger, L.A. Times (Jan. 7, 2007), http://articles.latimes.com/2007/jan/07/ opinion/op-hernandez7 (documenting attacks by Latinos against African Americans in Los Angeles).

${ }^{196}$ Cheryl K. Chumley, Black Youths Attack Hispanic Man: 'This is for Trayvon,' WASH. TiMEs (July 16, 2013), http://www.washingtontimes.com/news/2013/jul/16/black-youths-attack-hispanic-man-trayvon/.

${ }_{197}$ Robert Garcia, Latinos and Criminal Justice, 14 Chicano-Lntino L. Rev. 6, 18-19 (1994).

${ }^{198} \mathrm{Id}$. 
similarly to how African Americans were angry at the police officers who beat King. When Lopez's family was questioned about the incident, his daughter Melissa responded, “'Everybody says, 'It's your dad, don't you hate Black people?' . . . Well, the thing about us, thank God, is that we grew up all our lives around Black people. We know there are good people, bad people, O.K. people. There was really no hatred. I understand why they were so mad." "'199 In Melissa's case, the fact that she grew up around Blacks opened her mind to the reality that there are good, bad, racist and accepting people of all races; ${ }^{200}$ she had the capacity to understand the anger that Blacks felt even if they wrongfully channeled it toward her innocent father.

African-American and Latino communities understand racial oppression as it is lived in the United States, but the sad story is that the groups may, in turn, reproduce the legacy of racism if they do not actively identify and resist the racist tendencies inherent in any society that has a legacy of racism. ${ }^{201}$ "The concept of race is a variable construct reflecting a culture's viewpoint, and racism is thus a created belief that a society teaches its population." ${ }^{02}$ The communities must move away from the fallacy that because minorities did not have a hand in the creation of institutional power and institutional systems, racist members of minority groups cannot do harm ${ }^{203}$ through the exercise of individual power coupled with personal racism. ${ }^{204}$

$199 \mathrm{Id}$

${ }^{200}$ Perhaps this is a way to combat racism, getting to know, really getting to know (engaging in voluntary interactions by living in the same neighborhoods, inviting people of all races into our homes, playing together, attending houses of worship together, and sharing meals together), a critical mass of people of other races, especially in the formative years. See generally John D. Márquez, Black-Brown Solidartry: Racial. Politics in the New Gulf Sou't (2013). This way, individuals increase their odds of being open-minded and having less suspicion of people of other races. But it also depends on the messages individuals receive in their homes, which is where initial social values are formed, including patriarchal evils like racism and sexism. See infra note 403.

${ }^{201}$ See Robin D. Barnes, Race Consciousness: The Thematic Content of Racial Distinctiveness in Critical Race Scholarship, 103 HARv. L. Rev. 1864, 1867 (1990) ("This 'other' consciousness is reinforced across the generations in our familial and community interactions.").

${ }^{202}$ Kristina DuRocher, Raising Racists: The Socialization of White Children in THE JIM CROW SOUTH 6 (2011).

${ }^{203}$ Racism hurts and damages the spirit. Espinoza \& Harris, supra note 43, at 548. It also causes psychological, emotional, and physical damage. Richard Delgado, Words that Wound: A Tort Action for Racial Insults, Epithets, and Name-Calling, 17 HARv. C.R.-C.L. L. Rev. 133, 137-39 (1982).

${ }^{204}$ Individual racism by non-Whites against other non-Whites fuels institutional White supremacy. Espinoza \& Harris, supra note 43, at 517. Individuals exercise power over other individuals in certain settings and circumstances. When an individual chooses to profile or harass another individual, the harasser has power over the target. When a person has a gun that person has power. And, sometimes, the law gives individuals power even when the individual is not a state actor. These are the arguments that are being raised around the facts and laws surrounding the Zimmerman case. In the employment context, individual power is exercised all the time by those individuals who make decisions about other individuals, i.e., hiring and promotion decisions, evaluations, conditions of employment, allocation of resources, etc. These decisions by individuals drive the employment law cases when the decisions are based on unlawful discrimination and harassment. See Rhonda Reaves, Retaliatory Harassment: Sex and the Hostile Coworker as the Enforcer of Workplace Norms, 2007 Mich. ST. L. Rev. 403, 
Non-Whites can claim an interest in institutional racism. ${ }^{205}$ And institutional racism can, in turn, usher in "witting and unwitting personal racism."206 Personal decisions, such as voting, give citizens individual power in the institutional political process, and voting choices can be influenced by race and racism. The reliance on race and racism by citizens of the United States makes for "racialized politics" 207 during debates and resolutions about law and policy like comprehensive immigration reform. ${ }^{208}$

\section{African Americans on Immigration}

As the Supreme Court of the United States recently stated, "[i]mmigration policy shapes the destiny of the Nation." 209 And "immigration law sounds the alarm for racial minorities in the United States."210 African Americans are generally on the margins of the immigration debate because of the Latino-White immigration paradigm. ${ }^{211}$ This is ironic considering that Blacks have a long history of immigration to and migration within the United States. These experiences make African Americans potential allies for today's Latino immigrants; however, according to some Latino activists, many Blacks do not view the current immigration plight of Latinos as an issue that they should support. ${ }^{212}$

The claimed reasons for the lack of solidarity boil down to three main themes: nativism, economics, and politics. These arguments were explicitly stated in 2007 by Frank Morris, former Executive Director of the Congressional Black Caucus Foundation and former Dean of Graduate Studies at Morgan State University, and James G. Gimpel, Professor of Government at

411-12 (2008) (analyzing the role that individual peers and supervisors play in workplace harassment). We need to admit once and for all that, in certain contexts and situations, nonWhite individuals with racist tendencies have individual power to discriminate and do harm. See Espinoza \& Harris, supra note 43, at 538 n.131 (citing Bell. Hooks, TAlking BAck 113 (1989)).

${ }^{205}$ Ronald C. Griffin, Jubilee, 43 Washburn L.J. 353, 355 (2004) (citing John O. Calmore, Close Encounters of the Racial Kind: Pedagogical Reflections and Seminar Conversations, 31 U.S.F. L. Rev. 903, 924 (1997)). See also Harris \& González, supra note 187, at 12 (explaining that as people of color achieve critical mass in institutional settings, such as higher education, minorities may "simply reconfigure[ ] the racial and gender hierarchy, rather than eliminating it. In other words, the dominant racial group subordinates other racialized groups.").

${ }^{206}$ Griffin, supra note 205 , at 355 .

${ }^{207}$ See definition supra note 42.

${ }^{208}$ See McKanders, Personhood, supra note 119, at 167 (explaining that race and racism have fueled anti-immigrant laws).

${ }^{209}$ Arizona, $132 \mathrm{~S}$. Ct. at 2510.

${ }^{210}$ See Johnson, Race, the Immigration Laws, and Domestic Race Relations, supra note 115 , at 1154 .

${ }^{211}$ Lwin, supra note 10, at 107; Bill Ong Hing, Immigration Policies: Messages of Exclusion to African Americans, 37 How. L.J. 237, 237-39 (1994) [hereinafter Hing, Immigration Policies].

${ }^{212}$ Cord Jefferson, Why So Few Blacks Join Immigration Rallies, The Root (Mar. 30, 2010), http://www.theroot.com/views/why-so-few-blacks-join-immigration-rallies?page $=0,1$. 
the University of Maryland, as set forth in a report issued by the Center for Immigration Studies:

-While social scientists continue to debate the impact of large-scale immigration on low-skilled American natives, these same Americans certainly believe that high levels of immigration threaten their economic wellbeing. Current research shows that these fears are as much alive among African Americans as Caucasians. ${ }^{213}$

- Conflict between African Americans and Latina/os for group position, status, and political power is increasing as most immigrants of Hispanic ancestry settle in areas proximate to African American populations in the nation's largest cities. ${ }^{214}$

- African American gains in office-holding appear to be leveling off at higher levels of office, while Latino gains are rapidly rising. These gains are coming at the expense of non-Hispanic White office-holders and African Americans, though African Americans are more threatened given their smaller overall numbers. ${ }^{215}$

- Steadily rising immigrant populations will continue to change the racial complexion of U.S. House representation in a number of California, Texas, and New York congressional districts within the next 20 years. ${ }^{216}$

- With the 2010 census redistricting, just a few years away, as many as six seats currently held by members of the Congressional Black Caucus could be given up to Latino candidates. ${ }^{217,218}$

These arguments are examined and challenged below in subparts B, C, D, and $\mathrm{E}$ of this Part of the Article.

\section{A. The African-American Experiences with Immigration and Migration}

The " "forced migration immigration" of Africans may be characterized as the nation's first experience with immigration law and policy. ${ }^{219}$ However, slaves were not considered immigrants because Whites categorized them as chattel. ${ }^{220}$ Nonetheless, even if involuntarily, African slaves were labor-based immigrants. ${ }^{221}$ As U.S. Supreme Court Justice Antonin Scalia recently referenced in Arizona $v$. United States, ${ }^{222}$ southern states en-

${ }^{213}$ See discussion infra Parts III.B. and III.C.

${ }^{214}$ See discussion infra Part III.D.

${ }^{215}$ See id.

${ }^{216}$ See discussion supra Part II; see discussion infra Part III.B.

${ }^{217}$ See discussion infra Part III.D.

${ }^{218}$ Frank Morris \& James G. Gimpel, Immigration, Intergroup Conflict, and the Erosion of African American Political Power in the 21st Century, Backgrounder, CENTER FOR IMMIGRATION STUdies (Feb. 2007) (emphasis added).

${ }^{219}$ Rhonda V. Magee, Slavery as Immigration?, 44 U.S.F. L. REv. 273, 274-76 (2009).

${ }^{220}$ See id. at 276, 288.

${ }^{221}$ See generally id.

222132 S. Ct. 2492 (2012). 
acted "immigration" laws to stop the migration of freed Blacks to the South. ${ }^{223}$ In the century preceding 1875, states enacted immigration laws related to slavery, ${ }^{224}$ including laws that banned all Black immigration from one state to another and sought to exclude fugitive slaves. ${ }^{225}$ States also enacted Seamen's Acts that excluded free Black sailors from other countries. ${ }^{226}$ After slavery ended, African Americans continued to migrate to the North in search of a better life or to save their lives. ${ }^{227}$ For many, escaping the Jim Crow South was a matter of life or death. ${ }^{228}$

The migration of Blacks from the southern states of the United States to the northern states during the early twentieth century has been labeled "the Great Migration."229 Stories of the Great Migration during the years of 1915 to 1970 were beautifully documented in Isabel Wilkerson's book, The Warmth of Other Suns. ${ }^{230}$ In 1917, the country's leading Black newspaper, the Chicago Defender, began a campaign of encouraging Blacks to move to Chicago. ${ }^{231}$ Renowned poet and author Maya Angelou documented her own family's migration experience to Chicago and California in her book, I Know Why The Caged Bird Sings. ${ }^{232}$ African Americans from the South migrated to the North in search of opportunity, freedom, and dignity. ${ }^{233}$ Despite the abolitionist history in the North, Blacks encountered violence and exclusion when they arrived in the so-called "promised land." 234

${ }^{223}$ Id. at 2512 (Scalia, J., dissenting) (citing Gerald Neuman, The Lost Century of American Immigration (1776-1875), 93 Colum. L. Rev. 1833, 1835, 1841-80 (1993)); see also Elizabeth Keyes, Examining Maryland's Views on Immigrants and Immigration, 43 U. BALT. L.F. 1, 33 (2012) (noting the use of the term "immigration" to describe the movement of slaves from one state to another) (citing Arizona, 132 S. Ct. at 2512 (Scalia, J., dissenting)).

224 "Conceived broadly as the migration of individuals into a state, immigration encompasses both voluntary and involuntary movement." Neuman, supra note 223, at 1878 (citations omitted).

${ }^{225} \mathrm{Id}$. at 1880 (citing law enacted in Illinois).

${ }^{226} \mathrm{Id}$. at 1873-78. These state laws caused diplomatic conflicts with other countries, including with England and France. Id. at 1874-77.

${ }^{227}$ See generally ISABEL. WILKERSON, The WARMth of OTHER SUNS: The EPIC Story of AmERICA'S GREAT MigRATION (2010).

${ }^{228}$ Id. at $38-46$.

${ }^{229}$ Id. at 8-15; see generally Nicholas Lemann, The Promised Land: The Great Black Migration and How It Changed America (1992). African American migration within the borders of the United States did not entail the detention and deportation risks involved with undocumented immigration to the United States. See Johnson, Race, the Immigration Laws, and Domestic Race Relations, supra note 115, at 1113.

${ }^{230}$ See generally WILKERSON, supra note 227.

${ }^{231}$ LEMANN, supra note 229 , at 16.

${ }^{232}$ See generally Maya Angelou, I Know Why the Caged Bird Sings (1969).

${ }^{233}$ WILKERSON, supra note 227, at 8-15. Many Blacks were trying to escape the oppressive Jim Crow laws or running for their lives because they had failed to conform their conduct to White expectations of submission. See, e.g., id. at 170-72 (recounting story of cotton picker who left Eustis, Florida fearing for his life because "[t]he grove owners had it in for him because he had roused up the pickers. The pickers had turned on him out of fear for themselves").

${ }^{234}$ David B. Wilkins, The New Social Engineers in the Age of Obama: Black Corporate Lawyers and the Making of the First Black President, 53 How. L.J. 557, 571 (2010). The term "promised land" to refer to the North was coined in the title of a book about the Great Migration. Lrgmann, supra note 229. 
These experiences with migration in search of freedom and a better life should cause African Americans to empathize with the experience of today's undocumented immigrants. After all, the vestiges of the slavery immigration policy continue to drive today's racialized immigration strategies by, for example, exploiting minority immigrant labor without granting immigration status. ${ }^{235}$ But there seems to be a disconnect between the groups. Professor Geiza Vargas-Vargas pondered in one of her law review articles, in reference to mass incarceration and the failure to consider immigrant detention as part of the "New Jim Crow," whether Latinos are invisible to Blacks, "as blacks are to whites, such that we do not even enter the black consciousness." 236 Maya Angelou, in the autobiographical account of her migration from the South during the Great Migration, acknowledged and explained the failure on the part of African Americans to connect with the displacement of Japanese residents in San Francisco after African Americans took over the neighborhoods where Japanese had settled first:

A person unaware of all the factors that make up oppression might have expected sympathy or even support from the Negro newcomers for the dislodged Japanese. Especially in view of the fact that they (the Blacks) had themselves undergone concentration-camp living for centuries in slavery's plantations and later in sharecroppers' cabins. But the sensations of common relationship were missing. 2.37

Perhaps the disconnect can be explained by the view espoused by many Blacks that "the notion of considering slavery as a form of immigration seems like an inappropriate comparison."238 After all, "[m]ost Blacks who entered the country during the founding centuries were 'brought here in chains,' having been captured and sold, often by Africans from competing tribes, into slavery." ${ }^{239}$ This position appears to be related to the concept of "Black exceptionalism"-_" $\mathrm{t}] \mathrm{he}$ claim is, quite simply, that African Americans play a unique and central role in American social, political, cultural, and economic life, and have done so since the nation's founding" because of the experience of African ancestors with slavery. ${ }^{240}$

In its strongest form, black exceptionalism argues that what "white" people have done to "black" people is at the heart of the

${ }^{235}$ See Magee, supra note 219, at 283, 297; Gerald P. López, Don't We Like Them Illegal?, 45 U.C. DAvis L. Rev. 1711,1717 (2012).

${ }^{236}$ Vargas-Vargas, supra note 114, at 367. Professor Karla Mari McKanders has written two articles analogizing the treatment of African Americans during slavery and Jim Crow to the current treatment of immigrants and Latinos in the United States. See Karla Mari McKanders, Immigration Enforcement and the Fugitive Slave Acts: Exploring Their Similarities, 61 CATH. U. L. Rev. 921 (2012) [hereinafter McKanders, Fugitive Slave Acts]; McKanders, Personhood, supra note 119 , at 164 .

${ }^{237}$ Angelou, supra note 232, at 178.

${ }^{238}$ Magee, supra note 219, at 292.

${ }^{239} \mathrm{Id}$.

${ }^{240}$ Espinoza \& Harris, supra note 43, at 510. 
story of America; indeed, the story of "race" itself is the story of the construction of blackness and whiteness. In this story, Indians, Asian Americans, and Latino/as do exist. But their roles are subsidiary to, rather than undermining, the fundamental binary national drama. As a political claim, black exceptionalism exposes the deep mistrust and tension among American ethnic groups racialized as "nonwhite." 241

Maybe "black exceptionalism" explains why African Americans appear to be more connected to Black immigrants. ${ }^{242}$ Post-slavery Black immigration increased the African-American population in the United States. ${ }^{243}$ Overall, more Black immigrants from the West Indies immigrated to the United States than the total number of Blacks who entered as slaves. ${ }^{244}$ More recently, in the 1970s and 1980s, Blacks from Cuba, the Dominican Republic, Guyana, Haiti, Jamaica, Puerto Rico, and Trinidad and Tobago added to the Black demographics. ${ }^{245}$ Some African Americans initially resented these immigrants because many of them tended to be relatively skilled and educated. ${ }^{246}$ But self-interest made these Black immigrants more acceptable to African Americans because they would potentially identify with a Black political constituency. ${ }^{247}$

During the refugee crises of the 1980s and 1990s, the Congressional Black Caucus, with the help of Democrats, fought the deportation, asylum, and interdiction policies that promoted the repatriation of Haitians back to Haiti without affording them opportunities to apply for asylum. ${ }^{248}$ African Americans reacted to the ill-treatment of Haitians, as compared to the favorable treatment given to Cubans, ${ }^{249}$ because they saw the government's reaction as a racist policy against people of African descent. ${ }^{250}$ For African Americans in Miami, the harsh immigration treatment that Haitians received,

241 Id. at 517.

${ }^{242}$ See Ron Walters, Barack Obama and the Politics of Blackness, JoURNAL OF BLACK STUDIES 12 (2007).

${ }^{243}$ Virginia Yans-McLaughilin, Immigration Reconsidered: History, Sociology, AND POLITICS 306 (1990).

$244 \mathrm{Id}$.

${ }^{245} \mathrm{Id}$.

$246 \mathrm{Id}$.

${ }^{247} \mathrm{Id}$. at 308

248 Alejandro Portes \& Ai.ex Stepick, CtTy on the Edge: The Transformation of Miami 53-55 (1994); Sarah Anchors, Temporary Protected Status: Making the Designation Process More Credible, Fair, and Transparent, 39 ARIZ. ST. L.J. 565, 583-84 (2007).

249 The favorable U.S. immigration policy toward Cubans was instituted, in part, because Congress viewed the wave of Cubans that were fleeing Fidel Castro's regime as deserving of protection. Heather M. Kolinsky, A Fine Line, Redefined: Moving Toward More Equitable Asylum Policies, 40 U. BALT. L. REv. 649, 683 (2011). The discussions in Congress included references to the potential for assimilation of White Cubans, people "like us." Id. (citing Note, The Cuban Adjustment Act of 1966: ¿Mirando por los Ojos de Don Quijote o Sancho Panza?, 114 Harv. L. Rev. 902, 910-11 (2001)). For a nuanced discussion of the reasons for the preferential immigration treatment granted to Cubans, see Berta Esperanza Hernandez-Truyol, On Becoming the Other: Cubans, Castro, and Elian-A LatCritical Analysis, 78 DENV. U. L. REV. 687, 688-91 (2001).

${ }^{250}$ Hing, Immigration Policies, supra note 211 , at 237. 
in comparison to the more favorable immigration status afforded to Cubans, was not about immigration policy; it was about racial inequality "because they [Haitians] were black." 251

African Americans empathized with the plight of Haitians because they connected the racial subordination to their own racial experience in the United States. ${ }^{252}$ The racial solidarity that African Americans showed to Haitians helped to improve the immigration treatment of Haitians, ${ }^{253}$ although they never received treatment as favorable as that granted to Cubans under the Cuban Adjustment Act. ${ }^{254}$ Latinos who are fighting for comprehensive immigration reform want the support that African Americans gave to Haitians. Therefore, this Article confronts, in the subparts that follow, the forces that stand in the way of getting this support: nativism, fear of job competition, and apprehensions about sharing political power.

\section{B. Nativism}

Nativism is a primary axis of racialization in which Whites are at the top of the axis as the true "natives" and African Americans, based on their U.S. citizenship, fit at a lower point in the axis (due to their subordinated racial status). ${ }^{255}$ Their citizen status, even if second class in comparison to the privilege afforded to Whites along the axis, provides African Americans with a nativist way to distinguish themselves from immigrants-the "foreigners." 256 During the U.S. government's western expansion campaign, Black soldiers enforced U.S. imperial power against Native Americans and Mexicans living in what is now California and the southwestern states. ${ }^{257}$ Blacks used their U.S.-born citizenship to justify their failure to identify with the subordination of these oppressed groups. ${ }^{258}$ Therefore, nativism and antiimmigrant sentiment bring African Americans closer to Whites and their claim to a superior right to life in the United States. ${ }^{259}$

251 PoRTES \& STEPICK, supra note 248, at 54.

252 Johnson, Race, the Immigration Laws, and Domestic Race Relations, supra note 115 , at 1152 .

${ }^{253}$ PORTES \& STEPICK, supra note 248 , at 53-55.

${ }^{254}$ For a discussion of the immigration treatment granted to Cubans versus Haitians, see generally Heather Reynolds, Note, Irreconcilable Regulations: Why the Sun Has Set on the Cuban Adjustment Act in Florida, 63 FLA. L. Rev. 1013 (2011); Malissia Lennox, Note, Refugees, Racism, and Reparations: A Critique of the United States' Haitian Immigration Policy, 45 STAN. L. REv. 687 (1993).

${ }_{255}$ Hernídez, RaCial Subordination, supra note 41 , at 17. Thanks to the enactment of the Thirteenth and Fourteenth Amendments, the ruling in Dred Scott v. Sanford, 60 U.S. 393 (1856), wherein the United States Supreme Court held that emancipated and freed descendants of African slaves were not citizens under the Constitution of the United States, is no longer the law of the land. See Oliver v. Donovan, 293 F. Supp. 958, 967 (E.D.N.Y. 1968).

${ }_{256}^{250 v e l l ~ B a n k s, ~ s u p r a ~ n o t e ~} 49$, at $7,11$.

${ }^{257}$ ld. at 7,40 .

$258 \mathrm{Id}$.

${ }^{259}$ See Kevin R. Johnson, Racial Hierarchy, Asian Americans and Latinos as "Foreigners," and Social Change: Is Law the Way to Go?, 76 Or. L. Rev. 347, 351-52 (1997) [hereinafter Johnson, Racial Hierarchy]; Delgado, Locating Latinos, supra note 10, at 489-91. 
Following the theme of nativism, some African Americans reject immigrants because of what their presence means to the racial, cultural, and social composition of geographic areas in the United States where the majority and most visible minority group has been primarily African American ${ }^{260}$ For instance, in New Orleans, after Hurricane Katrina, the African-American mayor, other public officials, and local citizens "demanded action to halt immigrants from 'taking' American jobs and transforming the racial identity of a major southern city." 261 There were no qualms about the centrality of the discussion on race as it related to the city being "“overrun by Mexican workers" because, according to African-American mayor Ray Nagin, New Orleans is supposed to be a "chocolate [-not a Mexican-] city.""262

Nativist and racial considerations have been recurring themes in U.S. immigration law and policy. ${ }^{263}$ "Societal exclusion based on racist and nativist tendencies are certainly not novel ideas in American history." 264 The fear of immigrants of different races and ethnicities is embodied in the historical development of U.S. immigration law. ${ }^{265}$ In the 1800s, laws specifically aimed at excluding and deporting Chinese immigrants were enacted because racial hostility towards them had been growing for decades. ${ }^{266} \mathrm{Ra}$ cial bias played a major role in the campaign against Chinese immigration and the contemporaneous laws that were enacted to foreclose their naturalization. ${ }^{267}$ Booker $\mathrm{T}$. Washington argued that the Chinese, unlike Blacks, "lacked moral standards and could never be assimilated to occidental civilization." "268 The African-American press supported federal laws that excluded Chinese laborers in $1882 .{ }^{269}$ In the early 1900s, Black newspapers warned against Mexicans and Asians, who were alleged to be "unassimilable." 270

${ }^{260}$ See Néstor Rodríguez, New Southern Neighbors: Latino immigration and prospects for intergroup relations between African-Americans and Latinos in the South, 10 LATINO STUDIES 25 (2012).

${ }^{261}$ Kevin R. Johnson, Hurricane Katrina: Lessons About Immigrants in the Administrative State, 45 Hous. L. Rev. 11, 16 (2008) [hereinafter Johnson, Hurricane Katrina].

${ }_{262} \mathrm{Id}$. at 16. Hispanic presence in New Orleans dates back to the year 1500 , and in the 1940s there were already Costa Ricans, Cubans, Guatemalans, Hondurans, Mexicans, and Nicaraguans living in New Orleans. Augustina H. Reyes, Latino Children: U.S. Disaster and Educational Transformation, 10 WhitTlER J. ChILd \& FAM. Advoc. 53, 59 (2010).

${ }^{263}$ See Thomas Alexander Aleinikoft, David A. Mar'in \& Hiroshi Motomura, Immigration and Critzenship Process and Policy 171 (5th ed. 2003).

${ }^{264}$ McKanders, Personhood, supra note 119, at 166.

${ }^{265}$ See Aleinikoff, Martin \& Motomura, supra note 263, at 171.

${ }^{266}$ Angela M. Banks, Deporting Families: Legal Matter or Political Question?, 27 GA. ST. U. L. Rev. 489, 497-99 (2011). The fear of the Chinese in the 1800 s paved the way for the Chinese Exclusion Case, Chae Chan Ping v. United States, 130 U.S. 581 (1889). Strephen H. Legomsky \& Cristina M. Rodríguez, Immigration and Refugee Law and Policy 115-29 (5th ed. 2009).

${ }^{267}$ Hiroshi Motomura, Americans in Watting 73 (2006).

268 Yans-McLaughlin, supra note 243, at 296 (citing Arnold Shankman, Ambivalent

Friends: Afro-AmERICANS VIEW THE IMmigrant 16 (1982)).

${ }^{269}$ Id.

${ }^{270} \mathrm{ld}$. 
In recent times, the unexpected Latino presence in certain areas of the country has caused "[s]ignificant tension between the established African American community and Latina/o immigrants." 271 Demographers and political scientists are beginning to study a "little-studied phenomenon: the Latino in the U.S. South." 272 In Florida, Latinos who used to gravitate to South Florida are now moving to Central Florida, along the I-4 corridor. ${ }^{273}$ Latinos are also changing the population demographics in other states in the South, such as Alabama, Arkansas, Georgia, Louisiana, Mississippi, North Carolina, South Carolina, and Tennessee. ${ }^{274}$ Consequently, African Americans and Whites are facing Latinos in their daily lives like never before. ${ }^{275}$

Latino immigration has become "an important domestic issue for the forces of retrenchment, regression, and exclusion." 276 African Americans can distance themselves from the immigrant experience by playing on "nativist sympathies."277 Noncitizens who are not able to obtain citizenship are now in a similar position as "pre-Fourteenth Amendment freed Blacks, who could not even be counted among the citizens of this country. Lack of formal citizenship places the noncitizen, in the worst cases, into conditions that closely resemble slavery."278 Latinos, whether undocumented immigrants, lawful permanent residents, or even U.S. citizens, remain perpetual foreigners. ${ }^{279}$

As with the anti-Chinese laws, the rhetoric surrounding the enactment of state immigration enforcement laws, "Juan Crow' laws"280 like Arizona's S.B. 1070 and Alabama's H.B. 56, demonstrates that there is a racial aspect to the current immigration debate. ${ }^{281}$ In the South, the same region that enacted Jim Crow laws, the immigration debate "is racialized, even if race is rarely mentioned directly."282 The "birthright citizenship" movement also

${ }^{271}$ Johnson, Hurricane Katrina, supra note 261, at 49.

${ }^{272}$ Gregory B. WeEks \& JohN R. WEeks, Irresistible Forces: Latin American MiGRATION TO THE UNITED STATES AND ITS EFFECTS ON THE SOUTh 6 (2010). A recently published book examines the new coalitions between Latinos and African Americans in the Gulf South, in areas where the groups are living and experiencing similar realities and growing up together in the same neighborhoods. MÁrQUEZ, supra note 200.

${ }^{273}$ Rodríguez, Sáenz \& Menjívar, supra note 80, at 23. Most Puerto Ricans in Florida now live in Orlando. $I d$. at 24.

${ }^{274}$ Rodríguez, supra note 260 , at 19.

${ }^{275}$ Rodríguez, Sáenz \& Menjívar, supra note 80 , at xii.

${ }^{276}$ Montoya \& Valdes, supra note 29, at 189 (explaining that the McCain-Obama presidential race showed the continued persistence of pre-existing patterns of domination and subordination as demonstrated in the "presidential election debates surrounding immigration, and particularly Latina/o immigration").

${ }_{277}$ See Johnson, Hurricane Katrina, supra note 261 , at 63.

${ }^{278}$ Raquel Aldana, On Rights, Federal Citizenship, and the "Alien," 46 WASHBURN L.J. 263,266 (2007).

279 Johnson, Racial Hierarchy, supra note 259 , at 355 . In a similar parallel, during slavery, there was no distinction in the public mind between freed Blacks and Black slaves. Dred Scott, 60 U.S. at $411-12$.

${ }^{280}$ McKanders, Personhood, supra note 119, at 172.

${ }^{281}$ See generally id.

${ }^{282}$ WeEks \& Werks, supra note 272 , at 139. 
hides racist motives. ${ }^{283}$ African Americans have sometimes joined forces with Whites in support of restrictionist immigration measures that have damaged Latinos and Asians. ${ }^{284}$ One such anti-immigration coalition took place during debates on the Immigration Reform and Control Act of 1986 (IRCA). ${ }^{285}$ Some Blacks and Whites fought against the passage of IRCA and coalesced in opposition to Latino and Asian foreigners. ${ }^{286}$

Nativist hate groups like the Minutemen are actively recruiting African Americans, and anti-immigration groups like the Federation for American Immigration Reform (FAIR), a group that has been classified as a hate group by the Southern Poverty Law Center, ${ }^{287}$ are sponsoring African-American anti-immigrant groups. ${ }^{288}$ On June 3, 2013, one such group, the Black American Leadership Alliance (BALA), sent a letter "to members of the Senate's Gang of Eight and to members of the Congressional Black Caucus urging them to abandon immigration reform, claiming that reform would lead to 'higher unemployment, more poverty, and a lower standard of living for many in the black community." 289 U.S Senator Jeff Sessions, a Republican from Alabama, publicly thanked BALA for sending the letter. ${ }^{290}$

Under the guise of immigration enforcement, state anti-immigrant laws fueled by racist and nativist attitudes, similar to Jim Crow laws, codify and reproduce racist norms and discrimination. ${ }^{291}$ As during the Jim Crow regime, these anti-immigrant laws also promote extra-legal subjugation. ${ }^{292}$ Af-

${ }^{283}$ See generally Mary D. Fan, Post-Racial Proxies: Resurgent State and Local Anti"ALIEN" Laws and Unity-Rebuilding Frames for Antidiscrimination Values, 32 CArdozo L. REv. 905, 907 (2011).

${ }^{284}$ Johnson, The Struggle for Civil Rights, supra note 128, at 779.

${ }^{285}$ William M. Tamayo, When the "Coloreds" Are Neither Black nor Citizens: The United States Civil Rights Movement and Global Migration, 2 AsinN L.J. 1, 18-19 (1995).

${ }^{286}$ Robert S. Chang \& Neil Gotanda, The Race Question in LatCrit Theory and Asian American Jurisprudence, 7 NEv. L.J. 1012, 1020-21 (2007).

${ }^{287}$ The Southern Poverty Law Center has described FAIR, the Center for Immigration Studies, and NumbersUSA as three Washington, D.C.-based "immigration-restriction organizations that stand at the nexus of the American nativist movement." The Nativist Lobby: Three Faces of Intolerance, Southern Poverty LAw Center (Feb. 2009), http://www.spicenter.org/ get-informed/publications/the-nativist-lobby-three-faces-of-intolerance [hereinafter The Nativist Lobby].

${ }^{288}$ Leah Nelson, Strange Bedfellows: Nativists Sponsor, Tout New Black Anti-Immigrant Group, Southern Poverty LAw Center (Aug. 18, 2011), http:/www.splcenter.org/blog/ 2011/08/18/strange-bedfellows-nativists-sponsor-tout-new-black-anti-immigrant-group/.

${ }^{289}$ Miranda Blue, Meet the Black American Leadership Alliance, the Anti-Immigrant Movement's Newest Front Group, Right WiNG WATCH (June 7, 2013, 10:28 AM), http://www .rightwingwatch.org/content/what-black-american-leadership-association. The group's leader, Leah Durant, was an immigration lawyer with the U.S. Department of Justice for two years. Col. Allen West and Leah Durant on Next Generation TV, DC MARCH For JoBS, http://www .dcmarchforjobs.com $/ 2013 / 06 / 18 / \mathrm{col}$-allen-west-and-leah-durant-on-next-generation-tv/ (video interview with Col. Allen West).

${ }^{290}$ Brandon Moseley, Sessions Thanks Black American Leadership Alliance for Letter Opposing Gang of Eight Immigration Plan, Al.A. PoltTical. Reporter (Aug. 21, 2013), hitp:// www.alreporter.com/in-case-you-missed-it/4694-sessions-thanks-black-american-leadershipalliance-for-letter-opposing-gang-of-eight-immigration-plan.html.

${ }^{291}$ McKanders, Personhood, supra note 119, at 166-67.

${ }^{292}$ Id. Latinos, citizens and noncitizens, are actively being targeted by racist and xenophobic groups like the Ku Klux Klan. Id. at 168. For an account of the rise in hate crimes 
rican Americans can choose to find "interest convergence" 293 with Whites as they did when they supported anti-immigrant Proposition 187 in California, ${ }^{294}$ or they can find interest convergence with Latinos ${ }^{295}$ by recognizing that fighting against racial oppression may further the cause of African Americans in their fight for racial equality. ${ }^{296}$ Hopefully, African Americans will resist being dragged into the nativist movement that attacks immigrants and those associated with the status of perpetual foreigners. ${ }^{297}$

\section{Economics}

Some authors have tried to explain the ambivalent position of some African Americans toward immigrants on the basis of economics because Blacks have often competed with immigrants for low-level jobs. ${ }^{298}$ The job competition argument against immigration is not new. In the 1800 s, Frederick Douglas and Booker T. Washington complained about immigrants receiving better treatment and taking jobs away from Blacks. ${ }^{299}$ In the $1800 \mathrm{~s}$ and 1900s, rather than focus on the fight against the White establishment, including White-dominated unions that promoted racist employment practices, some African Americans adhered to a strategy of opposing immigration as a way to secure jobs that African Americans thought "rightfully should go to blacks." 300 In the 1920s and early 1930s, African-American leaders and newspapers encouraged proposals to bar Mexicans from entering the United States and supported the deportation of over 400,000 Mexicans. ${ }^{301}$

The reaction of African Americans like Douglas and Washington to immigration must be viewed in the context of the racial subjugation that African Americans experienced in the United States. These leaders saw White

against Latino immigrants, see María Pabón López, An Essay Examining the Murder of Luis Ramirez and the Emergence of Hate Crimes Against Latino Immigrants in the United States, 44 Arrz. ST. L.J. 155 (2012); Kevin R. Johnson \& Joanna E. Cuevas Ingram, Anatomy of a Modern Day Lynching: The Relationship Between Hate Crimes Against Latinalos and the Debate Over Immigration Reform, 91 N.C. L. REv. 1613 (2013).

293 "Interest convergence" is a term introduced as part of the Critical Race Theory Movement by the late Derrick Bell when he proposed that Whites made concessions for African Americans, not based on a sense of altruism or morality, but as a way to satisfy White selfinterest. Delgado, Locating Latinos, supra note 10, at 520.

${ }^{294} \mathrm{Id}$. at 521 .

${ }^{295}$ Interest convergence has generally not been applied to relations among minority groups. Id.

${ }^{296}$ See McKanders, Personhood, supra note 119, at 164 (advancing that state and local anti-immigrant laws lead to the segregation, exclusion, and degradation of Latinos from the rest of American society in the same way that Jim Crow laws marginalized African Americans).

${ }_{297}$ See Delgado, Locating Latinos, supra note 10, at 524.

${ }^{298}$ See Hing, Immigration Policies, supra note 211 , at 237-38. See also YANS-McLAUGHLIN, supra note 243, at 93 (analyzing the competition between Blacks and immigrants in New York in the 1900s).

${ }^{299}$ Yans-Mclaughlin, supra note 243, at 295. This fear of labor competition was the same fear expressed by White workers against Blacks in the South after emancipation. See Du Bols, supra note 123, at 45.

300 Yans-McLaughlin, supra note 243, at 295.

${ }^{301}$ Id. at 296. 
immigrants arrive in this nation and attain working opportunities that were denied to Blacks. ${ }^{302}$ In the competition for jobs, Blacks suffered from blatant race discrimination in employment whereas some immigrants, including Mexican and Chinese temporary migrant workers, were encouraged to come to the United States to perform jobs at lower wages and under conditions that Blacks would not accept. ${ }^{303}$ Immigrants were also employed in the 1900 s to defeat efforts by Blacks to organize unions. ${ }^{304}$

In 2007, T. Willard Fair, President and Chief Executive Officer of the Urban League of Greater Miami and Board Member of the Center for Immigration Studies, ${ }^{305}$ blamed mass immigration and "illegal aliens" for the educational and economic plight of African Americans. ${ }^{306} \mathrm{He}$ delivered his views in a statement before the Subcommittee on Immigration, Citizenship, Refugees, Border Security, and International Law Committee on the Judiciary U.S. House of Representatives. ${ }^{307}$ More recently, in June 2013, Fox News' Bill O'Reilly interviewed attorney Leah Durant, the founder of a bipartisan group of Black community leaders who oppose a path to citizenship for undocumented immigrants; the primary reason cited for their opposition was competition for jobs. ${ }^{308}$

White political pundits fuel the job competition argument. For example, Ann Coulter, ${ }^{309}$ at an annual Conservative Political Action Conference (CPAC 2013), responded as follows to a request for advice and for a date from a young, Black man from Ohio: "[Young, Black males] want jobs and they do not want to be competing with illegal aliens for jobs. You know, Blacks have been in this country longer than, their roots in America go back longer than most Whites. I think we owe them something more than someone who has just run across the border." 310

${ }^{302}$ See id. at 294-95. "Despite occasional exceptions such as Pullman-car portering, blacks differed from most other poor migrants in spreading across a wide range of jobs and industries, almost always in subordinate, insecure, and poorly paid positions. As a consequence, blacks have often found themselves competing unsuccessfully with the latest, poorest immigrants. This structural reality lies behind the ambivalent positions on immigration policy Lawrence Fuchs shows black leaders to have adopted." Id. at 93.

${ }^{303}$ See id. at 296-97.

${ }^{304}$ See id. at 297 (documenting that relatively educated Filipino workers were hired in the 1920 s by the Pullman Company to defeat attempts to organize Black workers).

${ }^{305}$ According to the Southern Poverty Law Center, the Center for Immigration Studies is a hate group. See The Nativist Lobby, supra note 287.

${ }^{306}$ See T. Willard Fair, Mass Immigration vs. Black America, CEnTER for IMMIGRation Srudies (May 9, 2007), http://www.cis.org/articles/2007/fairtestimony050907.html.

${ }^{307}$ See id.

${ }^{308}$ Mass Tea Party, Obama Pushing Immigration Reform - The Black Leadership Alliance - Leah Durant - O'Reilly, YouTube (June 11, 2013), http://www.youtube.com/watch?v=pAJ XN_FK1Jo; Challen Stephens, Black leadership group protests' disastrous effects of illegal immigration to the black community', ALl. Al_A. (June 3, 2013), http://blog.al.com/wire/2013/ 06/black_leadership_group_protest.html\#incart_river_default.

${ }^{309}$ Coulter has been described as a "right-wing attorney and author." Christine Tamer, Note, Arab Americans, Affirmative Action, and a Quest for Racial Identity, 16 TEx. J. ON C.L. \& C.R. 101, 114 (2010).

${ }^{310}$ Ann Coulter Remarks at Conservative Political Action Conference, C-SPAN (Mar. 16, 2013), http://www.c-spanvideo.org/program/311531-18 (statement at about 15:00 mark of 
Some African Americans oppose immigration due to concerns with the loss of low-skilled jobs. ${ }^{311}$ Professor Kevin R. Johnson examines the impact of immigrant labor on African Americans in his book, Opening the Floodgates: Why America Needs to Rethink Its Borders and Immigration Laws. ${ }^{312}$ According to Professor Johnson, there is some evidence to support the claim that substantial immigration of low-wage workers impacts the wages of the lowest-paid workers in the United States (but only slightly). ${ }^{313}$ However, he also notes that there are studies that show otherwise. ${ }^{314}$ More recently, the Congressional Budget Office (CBO) issued a report examining the economic impact of the immigration bill passed by the U.S. Senate, S. $744,{ }^{315}$ a bill that would grant legal status and a path to citizenship to potentially eleven million undocumented immigrants. ${ }^{316}$ The CBO concluded that passage of the bill would boost economic output. ${ }^{317}$ Additionally, the CBO made the following estimates:

[A]verage wages for the entire labor force would be 0.1 percent lower in 2023 and 0.5 percent higher in 2033 under the legislation than under current law. Average wages would be slightly lower than under current law through 2024, primarily because the amount of capital available to workers would not increase as rapidly as the number of workers and because the new workers would be less skilled and have lower wages, on average, than the labor force under current law. ... .

The estimated reductions in average wages and per capita GNP for much of the next two decades do not necessarily imply that current U.S. residents would be worse off, on average, under the legislation than they would be under current law....

...

video). The young man's question was about how "young, vocal, Black conservatives should deal with attacks from the liberal mob." $I d$.

${ }^{311}$ See Delgado, Linking Arms, supra note 181, at 875.

312 Kevin R. Johnson, Orrening the Flooj)gates: Why amirica NeEdos to Rethink Its Borders and Immigration LAws 143-47 (2007) [hereinafter Johnson, Opening the FIOODGATES].

${ }^{313}$ Id. at 145 .

${ }^{314} I d$. (citation omitted).

315 See A Guide to S. 744: Understanding the 2013 Senate Immigration Bill, ImmiGRATION POLICY Centrer 9-10, http:/www.immigrationpolicy.org/sites/defaultfiles/docs/ guide_to_s744_corker_hoeven_final_11-20-13.pdf [hereinafter GuiDE To S. 744] (last visited Nov. 27,2013 ).

316 Congressional Budget Office, The Economic Impact of S. 744, The Border Securtiy, Economic Opportuntty, and Immigration Modernization Act (June 2013), https://www.cbo.gov/sites/default/files/cbofiles/attachments/44346-Immigration.pdf. As of the writing of the last draft of this Article, the bill remains stalled in the House of Representatives where Speaker John Boehner says that it will not receive a vote. Ginger Gibson, John Boehner: No House vote on Senate immigration bill, POLITICO (July 8, 2013), http://www.politico .com/story/2013/07/john-boehner-house-immigration-vote-93845.html.

${ }^{317}$ Id. at 3 . 
The legislation would particularly increase the number of workers with lower or higher skills but would have less effect on the number of workers with average skills. As a result, the wages of lowerand higher-skilled workers would tend to be pushed downward slightly (by less than $1 / 2$ percent) relative to the wages of workers with average skills. ${ }^{318}$

As for high-skilled immigration, Republicans continuously push for immigration laws that favor foreign workers who come to the United States to work in highly remunerated areas. ${ }^{319}$ In September 2012, before President Obama's re-election, Republicans in Congress advocated for passage of a bill that would have increased visas for high-tech graduates by eliminating the diversity visa lottery program, a program that benefits many less educated Africans. ${ }^{320}$ The bill did not pass in the U.S. House of Representatives because Democrats defeated it. ${ }^{321}$ The House's Hispanic Caucus, Congressional Black Caucus, and Congressional Asian Pacific American Caucus opposed the bill because they argued that "Republicans were trying to increase legal immigration for people they want by ending immigration for people they don't want." 322

After the 2012 presidential election, when Latinos sent the message that comprehensive immigration reform is an important issue for them, ${ }^{323}$ Republicans attempted to show that they were beginning to consider the immigration issue by re-introducing a STEM $^{324}$ Jobs Act for highly-skilled visas during the lame-duck session. ${ }^{325}$ The bill was tied to a much-requested family unification provision that would have benefited many spouses and chil-

${ }^{318} \mathrm{Id}$. at 3,5 .

${ }^{319}$ See Mariela Olivares, Renewing the Dream: Dream Act Redux and Immigration Reform, 16 HARV. LATINO L. REV. 79, 109-11 (2013). The latest comprehensive immigration reform bill (U.S. Senate Bill 744) includes provisions that benefit employment-based immigrants in high-skilled areas. See GuIDE To S. 744, supra note 315 . In its response to President Obama's 2014 State of the Union Address, the GOP, through House Republican Conference Chair Cathy McMorris Rodgers (R-WA), indicated that the Republican party will honor the country's history of "legal immigration" and is "working on a step-by-step solution to immigration reform by first securing our borders and making sure America will always attract the best, brightest, and hardest working from around the world." Sarah Kliff, READ: The Republican response to the State of the Union address, WONKBLOG, WAsH. Post (Jan. 28, 2014), http://www.washingtonpost.com/blogs/wonkblog/wp/2014/01/28/read-the-republican-response -to-the-state-of-the-union-address/.

${ }^{320}$ House Considers Limited Republican Immigration Bill, Fox News LArino (Nov. 25, 2012), http://latino.foxnews.com/latino/politics/2012/11/25/house-considers-limited-repub lican-immigration-bill/.

$321 \mathrm{ld}$.

$322 \mathrm{Id}$.

${ }^{323}$ As Immigration Reform Returns to Agenda, Republicans Counter with 'Achieve Act', PBS News Hour (Nov. 28, 2012), http://www.pbs.org/newshour/bb/politics/july-dec 12/immi gration_1 1-28.html (Representative Luis Gutierrez (D-IL) explaining that Latino voters have spoken loud and clear about the need for comprehensive immigration reform).

${ }^{324}$ STEM stands for science, technology, engineering, and mathematics. See House Considers Limited Republican Immigration Bill, supra note 320.

$32.5 \mathrm{Id}$. 
dren of lawful permanent residents. ${ }^{326}$ By focusing on high-skilled immigration, Congress and corporations avoid providing funding for programs that train U.S. students and workers, including many African Americans and Latinos. ${ }^{327}$ During the current immigration debate, Republicans continue their efforts to bring more high-skilled foreign workers as part of comprehensive immigration reform, including in S. $744 .^{328}$

There are studies that indicate that high-skilled immigrants have a negative impact on Black employment in some industries. ${ }^{329}$ During the question-and-answer session after a speech by Department of Homeland Security Secretary Janet Napolitano, on November 13, 2009, a reporter from Hispanic Outlook Magazine asked about the issuance of $\mathrm{H}-1 \mathrm{~B}$ visas to foreign engineers when African-American and Hispanic engineers cannot secure placement in research programs and jobs. ${ }^{330}$ Secretary Napolitano downplayed the concern and responded that the question presented a "false dichotomy" because (1) there are enough engineering jobs for everybody; (2) the Department of Education is making sure that more American citizens increase their math and science skills to produce more U.S. citizens with engineering degrees; and (3) there is room for foreign students educated in American universities to stay here. ${ }^{331}$

Americans should consider that studies confirm that the United States derives economic benefits from the labor of low-skilled immigrants. ${ }^{332}$ These studies show that these immigrants actually improve local economic conditions by rejuvenating ailing industries. ${ }^{333}$ Industries that are drawing a Latino low-skill immigrant presence are creating managerial jobs for Blacks and Whites. ${ }^{334}$ The growth of the Latino population in the South has been credited by demographers and political scientists with ushering in a "new era of economic development, cultural revolution, and public policy." 335 African Americans should also bear in mind studies that show that Latino em-

${ }^{326} \mathrm{Id}$.

${ }^{327}$ Hing, Immigration Policies, supra note 211, at 278-80 (explaining that the need for high-skilled immigrants fails to address the domestic problems in education of people of color, especially African Americans). Workers and students already present in the United States include the DREAMers, "a group of undocumented young men and women who have been bravely lobbying for presidential and congressional action in the form of a DREAM Act, even while risking deportation." Reyes, DREAMers Keep on Dreaming!, supra note 106.

${ }^{328}$ Rebecca Kaplan \& Fawn Johnson, Hatch, Schumer Reach Deal on High-Skilled Workers in Immigration Bill, NAT'L J. (May 21, 2013), http:/www.nationaljournal.com/congress/ hatch-schumer-reach-deal-on-high-skilled-workers-in-immigration-bill-20130521. For a comprehensive summary of S. 744, see GuIDE To S. 744, supra note 315.

${ }^{329}$ Gonzalez, supra note 83, at 199.

330 Janet Napolitano, Sec'y of Homeland Sec., Speech at the Center for American Progress, Question \& Answer Session (Audio and Video) (Nov. 13, 2009), http://images2.american progress.org/Press/11-13\%20Napalitano\%20Event.mp3 (statement at 44:47 mark of audio).

$331 \mathrm{ld}$.

332 Johnson, Opening The Floodgates, supra note 312, at 146.

333 Gonzalez, supra note 83, at 199.

334 Lisa R. Pruitt, Latinalos, Locality, and Law in the Rural South, 12 Harv. Latino L. REv. 135, 148 (2009).

335 See, e.g., WeEks \& WeEks, supra note 272, at 165. 
ployment is a positive factor in non-Latino employment and should not fear Latino immigration on the basis of job competition. ${ }^{336}$

In cities like Miami, Florida, statistics show that "the influx of lowwage workers [in the 1980s] may have helped blacks in Miami by stimulating the local economy." 337 By moving up the economic ladder and leaving lower level jobs for recent immigrants, U.S. workers, including African Americans, benefit from higher paying jobs. ${ }^{338}$ This has already happened in Atlanta where African Americans have moved up the economic ladder and Latino immigrants have moved into the area to work in manual labor industries, such as agriculture and construction. ${ }^{339}$ Leaders in cities like Baltimore, Chicago, Cleveland, Columbus, Dayton, Detroit, Indianapolis, Lansing, Philadelphia, and St. Louis are waking up to this reality and promoting pro-immigrant policies in efforts to revitalize their cities. ${ }^{340}$ As President Obama told the nation during his 2014 State of the Union Address: "Independent economists say immigration reform will grow our economy and shrink our deficits by almost $\$ 1$ trillion in the next two decades." ${ }^{341}$

\section{Politics}

The increasing population and political clout of Latinos raise concerns for African Americans. ${ }^{342}$ For much of U.S. history, the three largest Latino groups in the United States originated from Mexico, Puerto Rico, and Cuba. ${ }^{343}$ As a result of immigration, the "browning of America" ${ }^{444}$ has been

${ }^{336}$ Rodríguez, Sáenz \& Menjívar, supra note 80, at 29.

${ }^{337}$ Kevin R. Johnson \& Bill Ong Hing, The Immigrant Rights Marches of 2006 and the Prospects for a New Civil Rights Movement, 42 HARv. C.R.-C.L. L. Rev. 99, 123 (2007).

${ }^{338}$ Pruitt, supra note 334 , at 148 ("Evidence thus suggests that growth of the industries drawing the Latina/o workforce is creating better jobs [managerial positions] for native workers.").

${ }^{339}$ WEEKS \& WEEKS, supra note 272, at 10 . Low-skilled immigrants are allowing African Americans to move up the economic ladder in the same way that immigrants helped Whites in the 1900s. See Yans-McLaughlin, supra note 243, at 143 (explaining that after World War I there were more opportunities for white-collar jobs, which were filled by native-born Whites, and this development freed lower-level jobs for recently arrived immigrants).

${ }^{340}$ Julia Preston, Ailing Midwestern Cities Extend a Welcoming Hand to Immigrants, N.Y. Times (Oct. 6, 2013), http://www.nytimes.com/2013/10/07/us/ailing-cities-extend-hand-to-im migrants.html?_r=1\&; Mario Quiroz-Servellón, Why It Makes Sense: African Americans and Latinos in Pro-Immigrant Baltimore, ONE NATION INDIVIsiBle (Feb. 2013), http://www.one nationindivisible.org/our-story/why-it-makes-sense-african-americans-and-latinos-in-pro-immi grant-baltimore/.

${ }^{341}$ President Barack Obama, President Barack Obama's State of the Union Address (Jan. 28, 2014), http://www.whitehouse.gov/the-press-office/2014/01/28/president-barack-obamasstate-union-address.

${ }^{342}$ Martínez, supra note 183 , at 213.

${ }^{343}$ Rodríguez, Sáenz \& Menjívar, supra note 80 , at vii.

${ }^{344}$ Maritza I. Reyes, Note, Latino Lawful Permanent Resident Removal Cases: A Case Study of Nicaragua and a Call for Fairness and Responsibility in the Administration of U.S. Immigration Law, I I HARv. LATINo L. REv. 279, 282 (2008) [hereinafter Reyes, Latino Lawful Permanent Resident Removal Cases] (citing Thomas David Jones, Human Rights: Freedom of Expression and Group Defamation Under British, Canadian, Indian, Nigerian and United States Law - A Comparative Analysis, 18 SuFfolk Transnat'l L. Rev. 427, 584 (1995)). 
a topic of much publicity throughout the United States in recent decades. ${ }^{345}$ These "brown" immigrants are people who entered the United States in the 1980s and 1990s - the great majority of them Latinos (and more specifically Mexicans). ${ }^{346}$ The immigration trend that began in the 1980 s is diversifying the national origins of Latinos in the United States. ${ }^{347}$ It is estimated that Salvadorans will soon become or have already become the third largest group, replacing Cubans. ${ }^{348}$ Latinos are becoming more visible in geographic areas of the United States where, until recently, the racial composition was predominantly Black and White, ${ }^{349}$ like in the South and in the Midwest. ${ }^{350}$ The majority of the eleven million undocumented immigrants who would benefit from a path to legalization and citizenship are Latinos (60\% Mexican). ${ }^{351}$ Some African Americans fear that the growing Latino population will usurp the "majority-minority" 352 political power and Blacks will be subjugated to a further inferior position. ${ }^{353}$

The political apprehensions of African Americans are emblematic of a system of racialized politics. ${ }^{354}$ This is not surprising when we consider that race underlies virtually any societal issue in the United States. ${ }^{355}$ " $[R]$ ace and racism continue to distort almost every social encounter and warp al-

${ }^{345}$ Lupe S. Salinas \& Fernando Colon-Navarro, Racial Profiling as a Means of Thwarting the Alleged Latino Security Threat, 37 T. Marshall L. Rev. 5, 22-24 (2011).

${ }_{346}$ Reyes, Latino Lawful Permanent Resident Removal Cases, supra note 344, at 283 (citing Adam B. Cox \& Eric A. Posner, The Second-Order Structure of Immigration Law, 59 Stan. L. Rev. 809, 810 (2007)).

${ }^{347}$ Rodríguez, Sáenz \& Menjívar, supra note 80 , at 4.

${ }^{348}$ Mark Hugo Lopez \& Ana Gonzalez-Barrera, Salvadorans May Soon Replace Cubans as Third-Largest U.S Hispanic Group, Pew Resianch Center (June 19, 2013), http://www .pewresearch.org/fact-tank/2013/06/19/salvadorans-may-soon-replace-cubans-as-third-largestu-s-hispanic-group/; Mark Hugo Lopez, Ana Gonzalez-Barrera \& Danielle Cuddington, Diverse Origins: The Nation's 14 Largest Hispanic-Origin Groups at 3 n.2, Pew Research HisPANIC TRENDS PROJECT (June 19, 2013), http://www.pewhispanic.org/files/2013/06/summary_ report_final.pdf.

${ }^{349}$ Native Americans lived in the South before and after colonization, but the tribes were forcefully removed from their indigenous lands in the 1830 s and 1840 s by the federal government. Carla D. Pratt, Loving Indian Style: Maintaining Racial Caste and Tribal Sovereignty Through Sexual Assimilation, 2007 WIs. L. Rev. 409, 415 n.25 (2007).

${ }^{350}$ Rodríguez, Sáenz \& Menjívar, supra note 80 , at 20-21.

${ }^{351}$ Unauthorized Immigrants: How Pew Research Counts Them and What We Know About Them, Pew Research Center (Apr. 17, 2013), http://www.pewresearch.org/2013/04/ 17/unauthorized-immigrants-how-pew-research-counts-them-and-what-we-know-about-them/.

${ }^{352}$ A fear of the "majority-minority" nation is shared by proponents and drafters of state immigration laws, like Arizona S.B. 1070, that aim to make the state environments so hostile that undocumented immigrants will self-deport. David A. Fahrenthold, Self-Deportation Proponents Kris Kolbach, Michael Hethmon Facing Time of Trial, WASH. PosT (Apr. 24, 2012, http://www.washingtonpost.com/politics/time-of-trial-for-proponents-of-self-deportation/2012/ 04/24/glQAe6lheT_story_1.html.

${ }^{353}$ Hutchinson, supra note 130, at 8-15 (asserting that the media depiction of Latinos as the top minority by the U.S. Census Bureau in 2002 "hit black America like a thunderbolt").

${ }_{354}^{35}$ See definition supra note 42.

${ }^{355}$ Gómez, supra note 4 , at 430 ("Race as a feature of social reality governs our interactions at the micro level (face-to-face interactions among individuals), as well as at the macro level in the ways that social institutions and organizations are structured."). 
most every facet of our social structure." 356 Today, politics in the United States are the most racialized that they have ever been. ${ }^{357}$ " $[\mathrm{T}]$ he fundamental fault line in racial politics is race itself." 358 Therefore, it is not unexpected that the immigration debate, a politically-driven issue, ${ }^{359}$ is also highly racialized. ${ }^{360}$ After all, formalized U.S. immigration law and policy was established to perpetuate race discrimination, ${ }^{361}$ and immigration laws mirror the mood of the country in response to the socially constructed races $^{362}$ of different groups at particular points in time. ${ }^{363}$

African Americans' fear of Latino political power became evident during the 2006 immigrant marches when many Latinos demanded comprehensive immigration reform. ${ }^{364}$ In reference to the marches, some African Americans voiced concern that Latino political power would derail the unfinished business of the Civil Rights Movement. ${ }^{365}$ Among some Latinos, there is suspicion (based on past experiences) that once African Americans obtain political power, Latinos are systematically excluded and subordi-

356 Ian Haney López, Racism on Trial: The Chicano Fight for Justice x (2003). Race discrimination is expressed throughout all aspects of society, including on one-on-one personal interactions. Note, Facial Discrimination: Extending Handicap Law to Employment Discrimination on the Basis of Physical Appearance, 100 HARV. L. REV. 2035, 2036 (1987).

${ }^{357}$ Daniel J. Hopkins, Politicized Places: Explaining Where and When Immigrants Provoke Local Opposition, 104 Am. Pol. Scr. Rev. $40-41$ (2010).

${ }^{358}$ Sears, Sidanius \& Bobo, supra note 42, at 237.

${ }^{359}$ The Supreme Court of the United States has firmly established that Congress has "plenary power" in the area of immigration legislation. Reyes, Constitutionalizing Immigration Law, supra note 108, at 652-53. "The political process is the central battlefield where the struggle for hearts and minds must be fought." Kevin R. Johnson, Civil Rights and Immigration: Challenges for the Latino Community in the Twenty-First Century, 8 LA RAzA L.J. 42, 51 (1995). Therefore, it is up to the people, through the political process, to decide the faith of comprehensive immigration reform.

${ }^{360}$ See Kevin R. Johnson, It's the Economy, Stupid: The Hijacking of the Debate Over Immigration Reform by Monsters, Ghosts, and Goblins (or the War on Drugs, War on Terror, Narcoterrorists, Etc.), 13 Chap. L. Rev. 583, 584 (2008). See also Jason DeParle, The AntiImmigration Crusader, N.Y. Times (Apr. 17, 2011), http://www.nytimes.com/2011/04/17/us/ 17immig.html?_r=1 (describing founder of three major anti-immigrant groups in the United States as "a man who increasingly saw immigration through a racial lens").

${ }^{361}$ Gabriel J. Chin, Regulating Race: Asian Exclusion and the Administrative State, 37 HARv. C.R.-C.L. L. REv. 1, 3 (2002) ("[T]he intellectual foundations of the immigration laws were eugenics and scientific racism.").

362 "The meaning of race has changed dramatically over time and between societies. To say that race is socially constructed is to suggest that society defines the reality of race, and this reality is reproduced daily through interpersonal exchanges as well as interactions with institutions." Deirdre M. Bowen, Meeting Across the River: Why Affirmative Action Needs Race \& Class Diversity, 88 Denv. U. L. Rev. 751, 756 (2011) (citations omitted).

${ }^{363}$ Chin, supra note 361 , at $18-22$ (explaining the racism behind the anti-Asian immigration laws).

${ }^{364}$ Rachel L. Swarns, Growing Unease for Some Blacks on Immigration, N.Y. TIMEs (May 4, 2006), http://www.nytimes.com/2006/05/04/us/04immig.html?_r=1 [hereinafter Swarns, Growing Unease].

${ }^{365}$ Id. 
nated. ${ }^{366}$ Despite political reservations and suspicions, Blacks and Latinos have come together to achieve success in political races. ${ }^{367}$

In 1989, in New York City, Latino and African-American voters carried David Dinkins, an African American, to victory in the mayoral race, defeating incumbent Ed Koch in the Democratic primary and Republican Rudy Giuliani in the general election. ${ }^{368}$ Latinos also helped African Americans to elect Harold Washington in Chicago, Tom Bradley in Los Angeles, Wellington Webb in Denver, and Ron Kirk in Dallas. ${ }^{369}$ African Americans eventually helped to elect Mayor Antonio Villaraigosa in Los Angeles. ${ }^{370}$ Jesse Jackson's "Rainbow Coalition" was based on the successful political experiences that resulted from the Black-Latino-White liberal-young-poor coalitions in Chicago and Philadelphia. ${ }^{371}$ Unfortunately, the Rainbow Coalition did not last beyond the 1990s because inter-group racial conflicts developed over jobs, power, and elected posts. ${ }^{372}$ After that, there were other state and local political coalitions, including in Texas where Democrats selected a "Dream Team" composed of the first Latino nominee for governor (Tony Sanchez), the would-be first African American senator (Ron Kirk) and the leading White Democrat (John Sharp) running for lieutenant governor. ${ }^{373}$ At the end, the Dream Team lost the election. ${ }^{374}$ Some blamed the lack of sup-

${ }^{366}$ See $\mathrm{V} \wedge \mathrm{C} \Lambda$, supra note 131, at 127-45 (discussing the systematic exclusion of Latinos in Campton, California once African Americans obtained political power).

${ }^{367}$ GonZALLEZ, supra note 83, at 179-80. Cuban Americans are the exception to the African American-Latino political coalition potential because, among other factors, Cuban Americans are majority Republicans and African Americans are majority Democrats. Id. at 181-82. However, as the recent re-election of President Obama demonstrates, Cuban-American political attitudes, even in Miami, Florida, are changing. Alessandra Hickson, Surprise! Obama Won Florida's Cuban Vote, NBCLATiNo (Nov. 9, 2012, 2:09 PM), http://nbclatino.com/2012/ 11/09/surprise-obama-won-floridas-cuban-vote/. African Americans and Cuban Americans found "interest convergence" when they joined forces to convince the Florida Legislature in 2000 to re-establish the Florida A\&M University College of Law (at the state's historically Black university) and to establish the Florida International University College of Law (at the state university with a near majority of Hispanic students). See Minorities in the Legal Profession, THE FLA. BAR, http://www.floridabar.org/DIVCOM/PI/BIPS2001.nsf/1119bd38ae090a7 48525676f0053b606/13b38d l d00f79d65852567c4007004b2! OpenDocument (last visited Mar. 12, 2014); Two Legislators Back New Law Schools, Minmi Herald, June 18, 1999, at 3B, available at 1999 WLNR 3352176. For the meaning of "interest convergence" see definition supra note 293.

${ }^{368}$ Josh Kurtz, New York Democrats' Dysfunction, Visible In Black and Brown, RoLL. CAl. (USA), Nov. 8, 2005, available at 2005 WLNR 18039751.

${ }^{369}$ Eric L. Hinton, 2008: The Year of the Latino, Diversity InC. Magazine 84 (Apr. 2008), http://www.diversityinc-digital.com/diversityincmedia/200804?pg $=86 \# p g 86$.

${ }^{370}$ Harold Meyerson, Opinion, L.A. coalitions are key to new mayor's triumph, NEWSIDAY, May 19, 2005, at A47, available at 2005 WLNR 8004903; see generally supra note 99.

${ }^{371}$ GonzaleEZ, supra note 83 , at $182-83$.

${ }^{372} \mathrm{Id}$. at 185 .

${ }^{373}$ Ronald Brownstein, Texas 'Dream Team' Carries Democrats' Hopes, L.A. Times (Oct. 19, 2002), at 13, available at 2002 WLNR 12411413.

374 Shut Out: The Dems Strike Out. . Again, The Texas Observer, Nov. 22, 2002, at 4, available at 2002 WLNR 11584400. 
port from White voters on race while others argued that it was strictly based on politics. ${ }^{375}$

Before the 2008 and 2012 presidential elections, some authors questioned whether African Americans and Latinos could move beyond their political conflicts and distrust. ${ }^{376}$ The results of these two presidential elections clearly showed that Latinos and African Americans can join together in support of the same political goal. The role that Latino voters played in the presidential election of November 2008 was scrutinized on a national level like never before because their votes were numerically significant. ${ }^{377}$ In that election Latinos helped Obama, an African-American politician, win in key states. $^{378}$ The 2008 Hispanic share of the state electorate exceeded the 2004 Republican margin of victory in Arizona, Colorado, Florida, Iowa, Nevada, New Mexico, and Texas. ${ }^{379}$ President George W. Bush received at least $30 \%$ of the Hispanic votes in each of these states in the 2004 national election. ${ }^{380}$

In the 2012 presidential election, Latinos once again supported President Obama in record numbers. ${ }^{381}$ Latinos voted for President Obama by a margin of $71 \%$ and the Latino share of the electorate rose from $9 \%$ in 2008 to $10 \%$ in $2012 .{ }^{382}$ Latinos helped to tilt the election in favor of Democrats in four key states: Colorado, Florida, Nevada, and Virginia. ${ }^{383}$ In Florida, thanks to the state's growing non-Cuban, Hispanic population and to changes in the political views of a segment of the Cuban-American population, ${ }^{384}$ President Obama's overall share of the Hispanic vote increased from $57 \%$ in 2008 to $60 \%$ in 2012 ; the Latino share of the electorate in the state rose from $14 \%$ in 2008 to $17 \%$ in 2012.385

When African Americans and Latinos reside in the same districts, the voting issues become more complex. A recent episode in New York City politics is a good example. African Americans and Latinos have a long history of political coalitions in New York in support of Democratic candidates. ${ }^{386}$ But during the 2012 election cycle, rivalry over political representa-

${ }^{375}$ Editorial, Focus: The election, SAN ANTONio Express-News, Nov. 13, 2002, at 06B, available at 2002 WLNR 13891635.

${ }^{376}$ See, e.g., Foley, supra note 182 , at 140 (evaluating the reasons for political conflict and distrust between African Americans and Latinos).

${ }_{377}$ Janai S. Nelson, Foreword, Making History: Race, Gender, and the Media in the 2008 Elections, 24 ST. John's J. Legal COMment. 101 (2009).

${ }^{378}$ Gómez, supra note 4 , at 426-27.

${ }^{379}$ Taylor \& Fry, supra note 55, at 21.

${ }^{380}$ ld. at 21.

${ }^{381}$ Lee, supra note 16.

${ }^{382}$ Lopez \& Taylor, supra note 111.

${ }^{383}$ Lee, supra note 16.

${ }^{384}$ See Hickson, supra note 367.

${ }^{385} \mathrm{Id}$; : Lopez \& Taylor, supra note 111 , at 5 . President Obama won the Cuban vote in Florida, albeit by a narrow margin. Hickson, supra note 367.

${ }^{386}$ See Reports, Appendix D: Minority Elected Officials in New York Post 1982, 17 S.

Cal. Rev. L. \& Soc. Just, 559 (2008). 
tion became an issue in Harlem. ${ }^{387}$ The New York Legislature failed to agree on the proposed redistricting plan presented by African-American and Latino leaders to create two Congressional seats, one predominantly African American and the other predominantly Hispanic. ${ }^{388}$ African-American and Latino leaders had sought to avoid having the communities compete against each other ${ }^{389}$ After the Legislature's failure, a federal district court took over the redistricting decision and created one district where the population is $55 \%$ Hispanic and $27 \%$ Black. ${ }^{390}$ The old district was $46 \%$ Hispanic and $26 \%$ Black. $^{391}$ The eligible Hispanic voters make up $45 \%$ and the eligible Black voters make up $34 \% .392$

As a result of the redistricting, long-term incumbent African-American U.S. Representative Charles Rangel ${ }^{393}$ faced a real challenge from Adriano Espaillat, a Dominican-born state legislator. ${ }^{394}$ Race-baiting plagued the political campaign. Politicians fueled racial strife between African Americans and a growing Dominican population. ${ }^{395}$ Espaillat argued that it was time for the Dominican community to be represented in Congress. ${ }^{396}$ Some Latino leaders threw their support behind Rangel and some African-American leaders threw their support behind Espaillat. ${ }^{397}$ In the end, Rangel won the race by a narrow margin and now represents a majority Hispanic district. ${ }^{398}$

African Americans and Latinos must overcome their fears and suspicions about each other. The groups must be conscious and aware that some people will prey on their fears and attempt to divide communities that can be stronger together rather than divided. The groups must resist the inclination to engage in racialized politics; instead, they should identify the best candidates for all communities and coalesce. ${ }^{399}$

387 John Eligon, Amid Racial Shift in Harlem, Political Pulpit Is in Play, N.Y. Times (Apr. 22, 2012), http://www.nytimes.com/2012/04/23/nyregion/black-politicians-fear-loss-of-prizedpulpit-in-harlem.html?pagewanted $=1$.

${ }^{388} \mathrm{Id}$.

${ }^{389} \mathrm{Id}$.

${ }^{390} \mathrm{Id}$.

${ }^{391}$ Jeff Mays, Vincent Morgan Drops out of Congressional Race, Gives Support to Espaillat, DNAINFo New York (Apr. 10, 2012, 9:51 AM), http://www.dnainfo.com/new-york/ $20120410 /$ harlem/vincent-morgan-drops-out-of-congressional-race-gives-support-espaillat.

${ }^{302}$ Eligon, supra note 387.

${ }^{393}$ Rangel, one of "the most influential African-American voices in the nation's capital," is African American on his mother's side and Puerto Rican on his absent father's side. Eligon, supra note 387; Sandra Lilley, Congressman Rangel in the race of his life against Latino candidate, NBCLATINo (June 24, 2012), http://nbclatino.com/2012/06/24/congressman-rangelin-the-race-of-his-life-against-latino-candidate/. At the time of the election, Rangel was attempting to recover politically after being found guilty of eleven ethics violations. Id.

${ }^{394}$ Mays, supra note 391.

${ }^{395}$ Id. Espaillat warned of " "nuclear political war' between blacks and Latinos in upper Manhattan if a Dominican seat was not created." $I d$.

396 Eligon, supra note 387.

${ }^{397}$ Mays, supra note 391.

${ }^{398}$ Halimah Abdullah, Rangel as Resilient as Harlem-Area District He Represents, CNN (June 27, 2012, 2:28 PM), http://www.cnn.com/2012/06/27/politics/rangel-primary/index.html.

399 "The future lies with multiracialism rather than one-party politics, with complexity rather than artificial simplicity, with a candid embrace of a booming, seething, polyglot world 


\section{Civil Rights Coalitions}

African-American and Hispanic coalitions may serve to define the sociopolitical future of the United States ${ }^{400}$ This Article acknowledges the tension between Blacks and Latinos as these groups often compete for limited resources. ${ }^{401}$ The groups are often pitted in a zero-sum game that creates difficulties for coalition building. ${ }^{402}$ There is also the issue of racism, an evil that persists, and minorities are not immune from its generational legacy and descent. ${ }^{403}$ But, as the 2008 and 2012 presidential elections demonstrate, there is hope for bringing the two groups together. The civil rights issues facing both communities are many. The groups must continue the conversation and identity ways to address the problems. Dialogue must translate into action through coalitions for the benefit of both communities and American society in general on civil rights issues like racial profiling, education, voting rights, and immigration. ${ }^{404}$

The Clinton-Obama primary media coverage illustrates how the African-American and Latino populations are often pitted against each other in politics. They are also segregated and marginalized by institutional policies that date back to Jim Crow laws. ${ }^{405}$ The harsh reality is that Blacks and Latinos continue to be disadvantaged in the United States. ${ }^{406}$ Both groups have suffered and continue to suffer the stigma, pain, and hardships of ra-

rather than a dismissively simplified one that will be increasingly out of touch with the world we inhabit." Delgado, Locating Latinos supra note 10, at 524.

${ }^{400}$ See WeEks \& WeEks, supra note 272, at 179.

${ }^{401}$ See, e.g., id. at 158.

402 McKanders, Black and Brown Coalition Building, supra note 100, at 479.

${ }^{403}$ Racial prejudice and racial resentment (based on group stereotypes), similar to many of the ideas and beliefs held during adulthood, develop during the early childhood years. Leland Ware \& David C. Wilson, Jim Crow on the "Down Low": Subtle Racial Appeals in Presidential Campaigns, 24 ST. John's J. Legal Comment. 299, 301 (2009). Growing up in segregated neighborhoods, schools, and places of worship perpetuates racist beliefs and suspicion of the "others" through conscious and unconscious racism. See Bill Ong Hing, Institutional Racism, ICE Raids, and Immigration Reform, 44 U.S.F. L. REv. 307, 323-24 (2009). Moreover, some members of minority groups voluntarily segregate from members of other minority groups, even if they share the same spaces in clubs, schools, and workplaces. See Aruna Lee, Korean-Latino Relations Growing Icy, New AM. MeDis (Mar. 12, 2007), http://news.newamer icamedia.org/news/view_article.html?article_id $=956104$ e550c2a5e61502487bd2912c9e\#.

${ }^{404}$ See generally Johnson \& Hing, supra note 337; accord McKanders, Black and Brown Coalition Building, supra note 100, at 497. Professor Richard Delgado points out that some scholars argue that coalitions are doomed to fail due to internal conflicts because one group is always trying to gain privilege for itself, even in coalitions among groups that aim to fight the same oppression. See Delgado, Locating Latinos, supra note 10, at 489 ("Privilege, in short, is relational and a matter of one's situation. For this reason, a coalition to end white privilege can easily find itself beset by internal antagonisms and sudden defections."). He suggests that groups that are similarly situated may gain more by working on common issues separately. Delgado, Linking Arms, supra note 181, at 876.

405 "More recently, residential segregation has been far more pervasive and long lasting for Blacks and now for Latinos than it ever was for Jews or other White ethnic groups." Daria Roithmayr, Racial Cartels, 16 Mich. J. RACE \& L. 45, 78 (2010).

${ }^{406}$ Delgado, Locating Latinos, supra note 10, at 504. 
cism because of the socially constructed racial differences from the White population. ${ }^{407}$

The alleged differences include claims of racial inferiority. Mexicans and Latinos in general were deemed racially inferior dating back to the Anglo expansion into the Southwest in the early to mid-1800s and these claims continued through segregation in the 1900s. ${ }^{408}$ Mexican Americans were socially constructed as an inferior race based on Anglo racial prejudices, which paved the way for legal discrimination. ${ }^{409}$ Similar claims of racial inferiority have been made about African Americans. ${ }^{410}$ The myth of racial inferiority served to rationalize slavery and Jim Crow segregation. ${ }^{411}$ Latinos, like African Americans, have been oppressed by Jim Crow laws and de jure and de facto segregation policies. Latinos were excluded from restaurants, parks, and swimming pools that were reserved for Whites. ${ }^{412}$ Latinos sat in the "colored" guests section of movie theaters. ${ }^{413}$ Latinos used the same bathrooms reserved for Blacks. ${ }^{414}$ Latinos were excluded from juries. ${ }^{415}$ Latinos could not be buried in cemeteries reserved for Whites. ${ }^{416}$ Mexicans were not immune from lynching:

Border violence was relentless between 1848 and 1928, resulting in the lynching of 597 Mexicans by vigilante mobs. The minority Mexican population faced unparalleled dangers from mob violence when compared to African Americans. Comparative data demonstrates that between 1848 and 1879 Mexicans were lynched at a rate of 473 per 100,000 of population. In comparison, African Americans [were] lynched at a rate of 52.8 victims per 100,000 of population in Mississippi between 1880 and 1930 (the time period and state in which African American lynchings were most rife).

${ }^{407}$ The process of racialization in the United States was long, intentional, and man-made. John A. Powell, Dreaming of a Self Beyond Whiteness and Isolation, 18 WASH. U. J.L. \& POL'Y 13, 26 (2005). The author of this Article proposes that it will take a similar long and intentional process by the people of the United States to alleviate the effects of racism.

${ }^{408}$ Ian Haney López, Race and Colorblindness After Hernandez and Brown, 25 ChicanoLatino L. Rev. 61, 63, 67-68 (2005) [hereinafter López, Race and Colorblindness]. "Their 'dark stream' of 'peon blood,' according to prominent eugenicist Madison Grant, rendered [Latinos] inferior even to the southern European Jews and Slavs." Delgado, Locating Latinos, supra note 10, at 493-94.

${ }^{409}$ Lopez, The Social Construction of Race, supra note 117, at 29.

${ }^{410}$ See, e.g., Chris Edelson, Judging in a Vacuum, or, Once More, Without Feeling: How Justice Scalia's Jurisprudential Approach Repeats Errors Made in Plessy v. Ferguson, 45 AKRON L. REV. 513, 524 (2012).

${ }^{41}$ Neuman, supra note 223, at 1867; Kimberle Williams Crenshaw, Race, Reform, and Retrenchment: Transformation and Legitimation in Antidiscrimination Law, 12 GERMAN L.J. 247, 277-78 (2011).

${ }^{412}$ Lupe S. Salinas, Immigration and Language Rights: The Evolution of Private Racist Attitudes into American Public Law and Policy, 7 Nev. L.J. 895, 909 (2007) (citations omitted).

${ }^{413}$ Id. (citations omitted).

${ }^{414}$ López, Race and Colorblindness, supra note 408, at 61-62 (citing a bathroom sign indicating "Colored Men" and "Hombres Aqui ["Men Here"]").

415 Id. at 61 .

${ }^{416}$ Salinas, supra note 412 , at 909 . 
After 1880 , there was a decline in the lynchings of Mexicans. Yet there were still 27.4 Mexican lynching victims per 100,000 of population, which exceeded the number of African Americans lynched in some of the southern states. The terrorizing of Mexicans by border vigilante groups continued into the twentieth century, with the last recorded lynching of a Mexican in the United States occurring on November 16, 1928.417

During the Great Depression, Mexican immigrants and U.S. citizens of Mexican ancestry were deported to Mexico. ${ }^{418}$

Claims of racial inferiority have even polluted the current comprehensive immigration reform debate, albeit in a camouflaged way. The Heritage Foundation (Heritage), a conservative group, released a paper opposing the U.S. Senate's comprehensive immigration reform bill due to the alleged economic costs of the bill. ${ }^{419}$ The Heritage paper was co-authored by Heritage quantitative analyst Jason Richwine, a man who earned a Ph.D. from Harvard University in $2009^{420}$ and wrote a dissertation concluding that "[f]rom the perspective of Americans alive today, the low average IQ of Hispanics is effectively permanent," in part due to genetics. ${ }^{421}$ Richwine proposed in his Ph.D. dissertation that the "growing Hispanic underclass" is "a socially isolated group of people for whom crime, welfare, labor force dropout, and illegitimacy are normal aspects of life." ${ }^{22}$ Following that premise, the Heritage paper submitted to the Senate argued that granting citizenship to today's undocumented immigrants would burden the United States' safety net and welfare programs. ${ }^{423}$

It should be evident to African Americans and Latinos that both communities have endured and continue to endure similar struggles. The pur-

${ }^{417}$ Peter Yoxall, Comment, The Minuteman Project, Gone in a Minute or Here to Stay? The Origin, History and Future of Citizen Activism on the United States-Mexico Border, 37 U. Minmi INTER-Am. L. Rev. 517, 522-23 (2006) (citing William D. Carrigan \& Clive Webb, The Lynching of Persons of Mexican Origin or Descent in the United States, 1848 to 1928, $37 \mathrm{~J}$. Soc. Hist. 411, 411, 413-14, 417 (2003)); see also Richard Delgado, The Law of the Noose: The History of Latino Lynching, 44 HARV. C.R.-C.L. L. REv. 297, 298, 305 (2009) (examining the invisibility of Latino lynching in historical records).

${ }^{418}$ Johnson, Race, the Immigration Laws, and Domestic Race Relations, supra note 115, at 1136 . "Approximately 60 percent of the persons of Mexican ancestry removed to Mexico in the 1930s were U.S. citizens, many of them children who were effectively deported to Mexico when their immigrant parents were sent there." Kevin R. Johnson, The Forgotten "Repatriation" of Persons of Mexican Ancestry and Lessons for the "War on Terror," 26 PACE L. REv. 1, 4 (2005) (citing Francisco E. Balderrama \& Raymond Rodríguez, Decade Of Betrayal: Mexican Repatriation in the 1930s 216 (1995)).

${ }^{419}$ Jon Ward, Jason Richwine Dissertation on Low Hispanic IQ Puts Heritage on Defensive /Full Document/, Huffington Post (May 9, 2013, 11:11 AM), http://www.huffington post.com/2013/05/08/jason-richwine-dissertation_n_3240168.html.

${ }^{420}$ Valerie Strauss, Harvard Students Seek Probe of Controversial PhD Thesis on Hispanics' IQ, WASH. POST (May 20, 2013, 1:32 PM), http://www.washingtonpost.com/blogs/answersheet/wp/2013/05/20/harvard-students-seek-probe-of-controversial-phd-thesis-on-hispanicsiq/.

${ }^{421}$ Ward, supra note 419.

${ }_{422}$ Id.

${ }^{423} \mathrm{Id}$. 
pose of recognizing shared suffering is not to compete as to who can make a better case for reparations. ${ }^{424}$ Rather, it is to acknowledge that there are more similarities in the experiences with oppression, segregation, and subjugation of Latinos and Blacks in the United States than are often acknowledged. ${ }^{425}$ Recognition of common struggles can serve to connect the groups in the fight against present inequality and racial injustice, and to sensitize them to each other's experiences in today's United States. This is better than continuously competing in a "hierarchy of oppression." ${ }_{426}$ The similar struggles of minority groups share the common bases of race and lack of privilege. ${ }^{427}$ "As compared to the illegal alien, the African American and those of us with U.S. citizenship are privileged. The anti-immigration climate stems from the same power trip, prejudice, and the fear of dark skin that has empowered whites to subordinate blacks, and originally, to subordinate the Native American." $" 428$

Some African Americans do not view the plight of Latino immigrants as a civil rights issue. ${ }^{429}$ At a conference where the issue of race relations between African Americans and Latinos was discussed, one of the panelists explained the situation in Washington, D.C. where African Americans outnumbered Latinos: "The federal government and other powers are treating African Americans in the District of Columbia very badly. But then sometimes [Latinos] fccl African Americans are doing to Latinos what others are doing to [African Americans]." 430 When Latino immigrants have faced

${ }^{424}$ The legacy of racism in the United States directly affects members of all racialized groups. See Richard Delgado, The Current Landscape of Race: Old Targets, New Opportunities, 104 Мich. L. REv. 1269, 1286 (2006).

All the groups are exceptional-blacks suffered slavery; Indians suffered removal
and extermination (what could be more foundational than that?); Mexican Ameri-
cans suffered conquest and the loss of one-half of their country in a pretextual war,
followed by colonial occupation and suppression of culture, language, and land ten-
ure. Puerto Rico is a United States colony, pure and simple. Japanese Americans
were interned during World War II, losing businesses, homes, and farms on the
strength of fabricated evidence, merely because they looked like the wartime enemy.

Id. at $1285-86$.

${ }_{425}$ See McKanders, Black and Brown Coalition Building, supra note 100, at 487-88.

${ }^{426}$ Vargas-Vargas, supra note 114 , at 367 . "Even if some hierarchy of oppression were ultimately to be constructed, we could not know which group should be placed where until we know each group's story." Espinoza \& Harris, supra note 43, at 557.

${ }^{427}$ Angela Mae Kupenda, Negotiating a Metaphorical Contract Between Blacker and Whiter America, 37 U. MEM. L. REv. 707, 710 (2007).

${ }_{428}$ Vargas-Vargas, supra note 114 , at 368.

${ }^{429}$ See Todd Johnson, Black Arizonans on the Fence About Immigration Law, THEGRIO (Apr. 26, 2010, 5:58 PM), http://thegrio.com/2010/04/26/black-arizonians-on-the-fence-aboutimmigration-law/. Conservative political commentator Ann Coulter expressed this same opinion during the Obama-Romney presidential race when she stated that immigrant rights are not civil rights while publicizing her book, Mugged: Racial Demagoguery from the Seventies to Obama. Megan Murphy, Ann Coulter: Civil Rights Are for Blacks, HuFfington Pos I Newsy, http://videos.huffingtonpost.com/ann-coulter-civil-rights-are-for-blacks-517489311 (last visited Oct. 28, 2013).

${ }^{430}$ Conference, National Council of La Raza 2001 Annual Conference: Selected Panels, 7 Tex. Hisp. J. L. \& Pol'y 13, 43 (2001). 
civil rights violations, leaders in the civil rights community have not come forward to provide support as readily as they usually react when the violations touch Black populations. ${ }^{431}$

One year before the Rodney King verdict, Latinos rioted in Washington, D.C. after a Black police woman shot a Latino. ${ }^{432}$ Latino leaders complained about the insensitivity of the district's police, which was primarily African American. ${ }^{433}$ An African-American councilman responded: "If they [Hispanics] don't appreciate our country, get out." ${ }^{434}$ A month after the riots, Clarence Mitchell, an African-American lobbyist for the National Association for the Advancement of Colored People (NAACP) told Hispanic leaders that Latinos do not have the same claim as African Americans to the benefits of civil rights that Blacks died to earn (like the right to vote). ${ }^{435} \mathrm{On}$ the other hand, some African Americans empathized with the plight of Latinos and saw a similarity with the struggle for civil rights faced by African Americans in earlier times. ${ }^{436}$ When the Los Angeles riots took place after the King verdict, African Americans were not alone in expressing the anger that they felt after the acquittal of the police officers who beat King. ${ }^{437}$ In fact, the majority of those arrested during the riots, $51 \%$, were Latinos. ${ }^{438}$ And, in addition to arrests, Latino immigrants faced sweeps that resulted in many deportations. ${ }^{439}$

The NAACP and the Leadership Conference on Civil Rights (LCCR) have at times been ambivalent about taking up the cause of immigrants. ${ }^{40}$ Moreover, African-American leaders have sometimes blamed the problems of the African-American community on non-White immigrants. ${ }^{441}$ African Americans were conspicuously absent from the 2006 immigrant marches. ${ }^{442}$ Some African Americans had a negative reaction to the marches. For example, Brendon L. Laster, a Black fund-raiser and part-time professor at Howard University, viewed the 2006 pro-immigrant marches and grew uncomfortable when Latinos began to talk about a new civil rights movement. ${ }^{443}$ Laster argued that "immigrant protesters who claim[ed] the legacy

\footnotetext{
${ }^{431}$ Tamayo, supra note 285 , at 3 .

${ }^{432}$ Gonzalez, supra note 83, at 144.

${ }^{433} \mathrm{Id}$.

${ }^{434}$ Id.
}

${ }^{435}$ Steven A. Holmes, Minority Leaders See A Clash of Hues In a Rainbow Coalition, N.Y. Times, June 16, 1991, at 44, available at 1991 WLNR 3066820.

${ }^{436}$ Id.

${ }^{437}$ Robert Garcia, Latinos and Criminal Justice, 14 Chicano-Latino L. Rev. 6, 12 (1994).

${ }^{438} I d$. at 6-7. Most of the Latino rioters were Central American immigrants. GonZALEZ, supra note 83, at 144. In comparison, $38 \%$ of the people arrested were African American, $9 \%$ were White, and $2 \%$ were Asian American or "other." Garcia, supra note 437, at 6-7.

${ }^{439}$ Johnson, Hurricane Katrina, supra note 261, at 56 (citing MANUEL PASTOR JR., ET AL.,

Latinos and the Los Angiles Uprising: The Economic Context 11-13 (1993)).

${ }^{440}$ Tamayo, supra note 285 , at 3 .

${ }^{441}$ Id.

${ }^{442}$ Johnson \& Hing, supra note 337 , at 102-05.

${ }^{443}$ Swarns, Growing Unease, supra note 364. 
of Dr. King and Rosa Parks [we]re going too far." $444 \mathrm{He}$ was worried "about the impact that the emerging immigrant activism w[ould] have on black Americans." ${ }^{445}$ Laster and other African Americans raised concerns about Latinos drawing similarities between their struggles and those of African Americans when Latinos did not suffer through slavery and the denial of basic rights despite U.S. citizenship. ${ }^{446}$ Linda Carter-Lewis, the branch president of the NAACP in Des Moines warned that the day would come when Latino immigrants would become citizens and usurp the power of African Americans. ${ }^{447}$

Additionally, the reluctance of some African Americans to join with Latinos on civil rights issues may be because they view Latinos as "unintended beneficiaries of the Civil Rights Movement." "448 This myth must be eradicated. Dr. King's son, Martin Luther King, III, in an interview with Al Sharpton on MSNBC's Politics Nation, on March 9, 2012, explained that his father had the vision to know that obtaining rights for Latinos was a goal of

$444 \mathrm{Id}$.

${ }^{445} \mathrm{Id}$.

${ }^{446} \mathrm{Id}$. U.S. citizenship did not grant Mexican Americans the right to keep their ancestral lands despite a treaty that promised that they were guaranteed "all rights of citizens of the United States," which presumptively included the right to keep land titles that the United States had promised to honor. Richard Delgado, Juan F. Perea \& Jean Stgfancic, LatiNOS AND THE LAw 15-16, 31 (2008). Most Americans are not familiar with the history of how Arizona, California, parts of Colorado, Nevada, and New Mexico became part of the United States after a war that the United States provoked. Id. at 8, 15, 20. The absence of the Treaty of Guadalupe Hidalgo of 1848 in legal or undergraduate education makes a significant statement of how certain events are left out of U.S. history. Id. at 20 . Puerto Ricans also attained U.S. citizenship but did not get "all rights of citizens of the United States." Id. at 41. Like Blacks, Mexican Americans were subjected to segregation because of their race. Juan F. Perea, Buscando América: Why Integration and Equal Protection Fail to Protect Latinos, 117 Harv. L. Rev. 1420, 1426, $1439-46$ (2004), reprinted in Delgado, Perea \& StizanciC, supra at 41-42. Mexican Americans and other Latinos had to mount legal fights in the courts to get the equal protection of the laws. Juan F. Perea, The Black/White Binary Paradigm of Race: The "Normal Science" of American Racial Thought, 85 CAL. L. REv. 1213, 1242-51 (1997); 10 LA RazA L.J. 127 (1998); Hernandez v. Texas, 347 U.S. 475 (1954), reprinted in Delgado, Pirisa \& Stefanic, supra at 42-47. And anti-Mexican racism translates into racism against persons of Mexican or Latino ancestry. See Delgado, Peren \& Stefanic, supra at 45 .

${ }^{447}$ Swarns, Growing Unease, supra note 364.

448 The author of this Article personally heard an African-American law professor make this statement in specific reference to Latinos and Asians during a Martin Luther King, Jr. Forum in 2012. The statement is sadly reminiscent of the language used in the Dred Scott decision in reference to descendants of African slaves: "We think they are not, and that they are not included, and were not intended to be included, under the word 'citizens' in the Constitution, and can therefore claim none of the rights and privileges which that instrument provides for and secures to citizens of the United States." Dred Scott v. Sanford, 60 U.S. 393, 404 (1856) (emphasis added). Other scholars recognize the broader application of civil rights laws and the inclusive reach of the Civil Rights Movement. See, e.g., Tamayo, supra note 285, at 34 (stating, "The U.S. Civil Rights Movement is rooted in a centuries-long struggle against the racism aimed not only at African Americans, but also at Latinos, Asian Americans, Arab Americans, and Native Americans. This fight has shaped the development of civil rights law and serves as a measuring stick for the Civil Rights Movement's progress."). 
the Civil Rights Movement. ${ }^{449}$ African-American scholars concur with this assertion. ${ }^{450}$

The U.S. Civil Rights Movement is rooted in a centuries-long struggle against the racism aimed not only at African Americans, but also at Latinos, Asian Americans, Arab Americans, and Native Americans. This fight has shaped the development of civil rights law and serves as a measuring stick for the Civil Rights Movement's progress. ${ }^{451}$

There should be no doubt that Latinos were intended beneficiaries as well as participants in the Civil Rights Movement. 452

Latinos actively participated in the fight for civil rights. ${ }^{453}$ Chicano militants marched with African Americans. ${ }^{454}$ Mexican Americans and Puerto Ricans joined the struggle. 455 For instance, Mexican-American folk singer Joan Baez financed the campaign to integrate a Grenada, Mississippi school in 1966 and walked with Dr. Martin Luther King, Andrew Young, and Hosea Williams. ${ }^{456}$ Like Baez, Puerto Rican actress and singer Rita Moreno joined the 1963 March on Washington. ${ }^{457}$ Civil rights leaders César Chávez and Dr. King supported each other. ${ }^{458}$ The Mexican farm worker movement in the 1950s and 1960s inspired Dr. King to send Chávez a letter of support. ${ }^{459}$ Additionally, Dr. King's top aide, Ralph Abernathy, protested alongside Chávez, and Dr. King's wife, Coretta Scott King, showed solidarity on behalf of her husband and of herself when she visited Chávez in jail. ${ }^{460}$ "Chavez was profoundly grateful for the support he got from King. Every chance he got, he praised King as his mentor, as the man who was his greatest inspiration." 461

The Black community should follow the lead of civil rights lawyers that have identified immigrants as pivotal to the future of the Civil Rights Movement in the twentieth and twenty-first centuries. In 1995, attorney William

${ }^{449}$ GOP's ObamaScare Methods, MSNBC (Oct. 25, 2013), http://www.msnbc.msn.com/ id/45755884/\#46687460.

${ }_{450}$ See, e.g., Roy L. Brooks \& Kirsten Widner, In Defense of the Black/White Binary: Reclaiming a Tradition of Civil Rights Scholarship, 12 BERKELEY J. AFr.-AM. L. \& POL'Y 107, 110 (2010) ("We know of no respectable African American scholar who would argue that nonblack racial groups should be relegated to second-class civil rights treatment.").

451 Tamayo, supra note 285 , at 3-4.

${ }^{452}$ See, e.g., McKanders, Black and Brown Coalition Building, supra note 100, at 492-96; Johnson, The Struggle for Civil Rights, supra note 128, at 773.

${ }^{453}$ Hurchinson, supra note 130 , at 48.

${ }^{454}$ Lopez, White Latinos, supra note 126 , at 5.

${ }^{455}$ Gonzalez, supra note 83, at 176; Hutchinson, supra note 130 , at 48.

${ }^{456}$ Leslie G. Kelen, This Light of Ours: Activist Photographers of the Civil. Rights Movement 101 (2011).

${ }^{457}$ Robin S. Doak, The March on Washington: Untting Against Racism 54, 58 (2008).

${ }_{458}$ GonZalez, supra note 83 , at 176; Hutchinson, supra note 130 , at 48 .

${ }^{459}$ Hutchinson, supra note 130 , at 48 .

${ }^{460} \mathrm{Id}$.

${ }^{461} I d$. 
R. Tamayo posited that the African-American community had to become involved in the pro-immigrant struggle against racism because AfricanAmerican support could determine the success of other minority communities in their battle against the racism underlying immigration policy. ${ }^{462} \mathrm{Mr}$. Tamayo proposed that African-American civil rights leaders needed to make "coalition efforts ... an integral part of a Civil Rights Movement agenda for protecting the rights of the non-Black, non-White immigrant population in America." 463 More recently, in 2006, a senior African-American policy maker in North Carolina noted that, "there should be important points of agreement between Blacks and Latinos in terms of civil rights, particularly since illegal immigrants work under a "new system of slavery." 464 Admittedly,

The civil rights movement in the 1960 s was very much about civil rights for blacks, whose enslavement and segregation has a lasting legacy in modern America, but it also advocated for the civil rights of other minorities. Incorporating similarly broad civil rights concerns in a movement that also includes the goal of guaranteeing the rights of immigrants would build much-needed political support for change. ${ }^{465}$

By joining with Latinos in support of civil rights for immigrants, African Americans may gain the renewed energy that newcomers can bring to the fight for racial justice and for Dr. King's dream of civil rights for all in the United States. However, if African Americans and Latinos are going to learn to coalesce, the groups must be proactive and conscious about recognizing their similar and different experiences with oppression.

[T] he two groups have minimal awareness of the other's experiences and perspective. Many new Latino immigrants know little about slavery, the civil rights movement, and the relegation of large numbers of Blacks to poverty today. Likewise, many African Americans are unaware of the structural dynamics of globalization that lead many Latino immigrants to seek work in the United States despite their inability to obtain a visa. ${ }^{466}$

It is crucial to incorporate immigrants as equal participants in the Civil Rights Movement rather than as outsiders in a second-class status at the margins of the movement. This is vital if the African-American and Latino communities are going to fight together against civil rights violations like

${ }^{462}$ Tamayo, supra note 285 , at 5 .

${ }^{463}$ Id. at 31 .

${ }^{464}$ WeEks \& WEEks, supra note 272 , at 160 (citing Interview with GBW, in Charlotte, N.C., (Jan. 11, 2006)).

465 Johnson \& Hing, supra note 337, at 101.

${ }^{466}$ Jennifer Gordon \& R.A. Lenhardt, Conflict and Solidarity Between African American and Latino Immigrant Workers, The Chisf Justice EArl Warren Institute on Race, EthNictTy, AND Diverstry, UniverstTy of CAlifornia, Berkel,Ey LAW SCHOOl, ii-iii (2007), http://www.law.berkeley.edu/files/GordonLenhardtpaperNov30.pdf. 
racial profiling, inequitable access to education, voter disenfranchisement, and oppressive immigration practices.

\section{A. Racial Profiling}

Similar to the experiences voiced by President Obama in his comments to the country after the Zimmerman verdict, ${ }^{467}$ many Latinos have first-hand experiences with racial profiling. ${ }^{468}$ Terminology used to describe a form of racial profiling, "driving while Black," 469 has an analogous terminology of "driving while brown." 470 Also in today's anti-immigrant climate, state immigration enforcement "show me your papers laws" make Latinos prone to additional racial profiling. ${ }^{471}$ Some state law enforcement officers are increasingly targeting Hispanics, citizens and non-citizens, for traffic stops and arresting them for minor traffic infractions in the hope of catching undocumented immigrants who can then be referred for deportation. ${ }^{472}$ Some state actors also participate in the federal Secure Communities program, ${ }^{473}$ a program through which state police officers collaborate with U.S. Immigration and Customs Enforcement (ICE) in the identification of immigrants who may be removable. ${ }^{474}$ The program encourages racial profiling because it essentially creates a dragnet for anyone who is arrested (regardless of whether they are ever charged with a crime) to be referred to and detained by ICE. ${ }^{475}$

${ }^{467}$ Earl Ofari Hutchinson, Obama Rams the Issue of Racial Profiling Back Onto the Nation's Table, The HufFington Post (Juj.Y 21, 2013, 10:12 AM), hitp://www.huffingtonpost .com/earl-ofari-hutchinson/obama-racial-profiling_b_3628522.html?utm_hp_ref=trayvonmartin.

${ }^{468}$ See, e.g., Kevin R. Johnson, How Racial Profiling in America Became the Law of the Land: United States v. Brignoni-Ponce and Whren v. United States and the Need for Truly Rebellious Lawyering, 98 GEo. L.J. 1005, 1038, 1042 (2010) [hereinafter Johnson, How Racial Profiling Became the Law]; Reyes, A Latina Law Professor's Personal Perspective, supra note 36.

${ }^{469}$ The term "driving while Black" describes how African Americans are routinely stopped because they fit a racial profile. OGLETREE, supra note 123, at 101-14 (exploring the issue of racial profiling in traffic stops and searches in the chapter "Driving While Black. Fighting Back Against Racial Profiling")

${ }^{470}$ For Latinos, citizens and noncitizens, "driving while brown" subjects them to traffic stops in search of criminality and unauthorized immigration status. Kevin R. Johnson, The Song Remains the Same: The Story of Whren v. United States in RACE LAW STORIES 421 (Devon W. Carbado \& Rachel E. Moran eds., 2008).

${ }^{471}$ Karla Mari McKanders, Federal Preemption and Immigrants' Rights, 3 WAKE FOREST J.L. \& PoL'Y 333, 357 (2013) [hereinafter McKanders, Federal Preemption]; Angela M. Banks, The Curious Relationship Between "Self-Deportation" Policies and Naturalization Rates, 16 LEwIS \& C CARK L. REv. 1149, $1187-96$ (2012) [hereinafter Banks, "Self Deportation"].

${ }^{472}$ McKanders, Federal Preemption, supra note 471, at 356-57; Banks, "Self Deportation," supra note 471 , at 1187.

${ }^{473}$ For the official description of the Secure Communities program, see ICE, Secure Communities, http://www.ice.gov/secure_communities/.

${ }^{474}$ Amelia Fischer, Secure Communities, Racial Profiling, \& Suppression Law in Removal Proceedings, 19 TEX. Hisp. J. L. \& POL.'Y 63, 66 (2013).

${ }^{475}$ See id. at 67. 
African Americans and Latinos are targets of racial harassment by police officers. ${ }^{476}$ They are also victims of flagrant race discrimination in the criminal justice system from stop, arrest, charge, conviction, and sentencing, to imprisonment. ${ }^{477}$ In addition, in United States v. Brignoni-Ponce, ${ }^{478}$ the U.S. Supreme Court held that Mexican appearance is a relevant factor that immigration officers may consider in determining whether to stop a person to ascertain whether he or she is a noncitizen. ${ }^{479}$ After this holding, racial profiling is legally allowed in the immigration context. ${ }^{480}$ The association of U.S.-born Latinos with immigrants provides one more reason for Latinos or those who fit the stereotypical Latino physical appearance profile to be stopped and harassed by police. ${ }^{481}$ A federal district court in Arizona recently held that Maricopa County Sheriff Joe Arpaio has unlawfully racially profiled Latinos under the guise of immigration control. ${ }^{482}$

Professor Kevin R. Johnson, in a law review article in 2003, advocated that African Americans, Latinos, and other racial minorities should form coalitions to challenge racial profiling in law enforcement. ${ }^{483}$ One such coalition succeeded in its class action challenge of the racial profiling in stopand-frisk practices by the New York City Police Department. ${ }^{484}$ A judge found that the stop-and-frisk practices that targeted primarily Black and La-

${ }^{476}$ See generally Kevin R. Johnson, The Case for African American and Latinalo Cooperation in Challenging Racial Profiling in Law Enforcement, 55 F $\mathrm{I}_{\text {. }}$. L. REv. 341 (2003) [hereinafter Johnson, Challenging Racial Profiling].

${ }^{477}$ See id. at 343 .

${ }^{478} 422$ U.S. 873 (1975).

${ }^{479} \mathrm{ld}$. at $886-87$.

480 Johnson, How Racial Profiling Became the Law, supra note 468, at 1007. U.S. Border Patrol agents of Mexican ancestry actively participate in racial profiling immigrants in jurisdictions geographically close to the U.S.-Mexico border. García Hernández, La Migra in the Mirror, supra note 124, at 894-96.

${ }^{481}$ Kevin R. Johnson, The Case Against Race Profiling in Immigration Enforcement, 78 WASH. U.L. Q. 675, 694-95 (2000); Jennifer M. Chacón, A Diversion of Attention? Immigration Courts and the Adjudication of Fourth and Fifth Amendment Rights, 59 DuKe L.J. 1563, 1617 (2010); César Cuauhtémoc García Hernández, The Perverse Logic of Immigration Detention: Unraveling the Rationality of Imprisoning Immigrants Based on Markers of Race and Class Otherness, 1 Colum. J. RACE \& L. 353, 359 (2012); Banks, "Self Deportation," supra note 471 , at $1190-93$.

${ }^{482}$ Scott Neuman, Court Rules that Arizona Sheriff Engages in Racial Profiling, NPR (May 24, 2013), http://www.npr.org/blogs/thetwo-way/2013/05/24/186521745/court-rulesthat-arizona-sheriff-engages-in-racial-profiling. For the district court decision, see Melendres v. Arpaio, No. PHX-CV-07-02513-GMS, 2013 WL 2297173 (D. Ariz. May 24, 2013).

${ }^{483}$ See generally Johnson, Challenging Racial Profiling, supra note 476.

${ }^{484}$ Floyd, et al. v. City of New York, et al., CIenter For Consitrutional. Rights, http:/l ccrjustice.org/floyd (last visited Mar. 4, 2014) (summarizing Floyd, et al. v. City of New York, et al., a federal class action lawsuit filed against the New York City Police Department (NYPD) and the City of New York that challenged the NYPD's practices of racial profiling and unconstitutional stop-and-frisks). "According to the ACLU in New York, between 2002 and 2011 , black and Latino New Yorkers made up close to 90 percent of those stopped by police88 percent of whom had no weapons or drugs on them when it happened." Brentin Mock, Is Obama Poised to Create Stop-and-Frisk Nation?, Color Lines (July 18, 2013, 1:51 PM), http://colorlines.com/archives/2013/07/obama_wants_ray_kelly_for_homeland_security_stopand-frisk_nation.html. 
tino males were unconstitutional. ${ }^{485}$ In January 2014, New York City Mayor Bill de Blasio announced that the City would settle the lawsuits. ${ }^{486}$ These coalitions need to continue.

\section{B. Education}

Education has been at the heart of the oppression of African Americans and Latinos in the United States. By denying minority children access to a high quality education, the future of these communities is put in jeopardy. The failure of the education system causes other social ills that plague the African-American and Latino communities. The groups identified education, starting with the fight to desegregate schools, as one of the goals of the Civil Rights Movement. In the desegregation context, Mexican Americans were successful in Westminster $v$. Mendez ${ }^{487}$ and African Americans in Brown v. Board of Education. 488 In Mendez, eight years before Brown, Blacks and Latinos united in furtherance of their common interest-desegregation of public schools. ${ }^{489}$ Mexican-American parents brought an equal protection challenge to racial segregation in their local public schools and the NAACP filed an amicus brief on their behalf that served as "a practice run for the arguments that later carried the day in Brown." ${ }^{490}$ The district

${ }^{485}$ Floyd v. City of New York, No. 08 Civ. 1034(SAS), 2013 WL 4046209 (S.D.N.Y. Aug. 12, 2013).

${ }^{486}$ Benjamin Weiser \& Joseph Goldstein, Mayor Says New York City Will Settle Suits on Stop-and-Frisk Tactics, N.Y. TimEs (Jan. 30, 2014), http://www.nytimes.com/2014/01/31/nyre gion/de-blasio-stop-and-frisk.html?hpw\&rref=nyregion.

${ }^{487} 64$ F. Supp. 544 (S.D. Cal. 1946) [hereinafter Mendez I], aff'd on other grounds, 161

F.2d 774 (9th Cir. 1947) [hereinafter Mendez II].

488347 U.S. 483 (1954).

${ }^{489}$ The parties stipulated that there was no question of race segregation because they agreed that the Mexican children were White. Mendez I, 64 F. Supp. at 546. Amicus brief writers (including the NAACP) did not agree with this assertion. Mendez II, 161 F.2d at 780. The Ninth Circuit noted that this difference could be held to place the case outside the Supreme Court segregation cases. Id. But the courts did not rule on this issue. Rather, the Ninth Circuit ruled for the plaintiffs (appellees) on the basis that the California law did not specify that Mexican children should be segregated. Id at 780-81. This caused a rift between African Americans and Mexican Americans. Martínez, supra note 183, at 215. It is important to remember that judicial opinions confirm that members of all subordinated racial groups have, at one time or another, attempted to evade membership in subordinated groups to gain the privileges of whiteness, including freedom from slavery. See, e.g., Lopez, The Social Construction of Race, supra note 117, at 1-3 (documenting how three mixed race (African, European, and Native American) women claimed exclusive Native American ancestry in a Virginia court in 1806 in order to gain freedom) (citing Hudgins v. Wright, 11 Va. (1 Hen. \& M.) 134 (Sup. Ct. App. 1806), excerpted in Paul Finkelman, The Law of Freedom and Bondage: A Casebook 22-24 (1986)).

${ }^{490}$ Michael V. Hernandez, Bridging Gibraltar: Latinos as Agents of Reconciliation in Relations Between Black and White America, 11 LA RAZA L.J. 99, 108-09 (2000). One of the authors of the NAACP's amicus brief was attorney Thurgood Marshall who went on to become the first African-American Justice of the United States Supreme Court. Hon. Frederick P. Aguirre, Mendez v. Westminster School District: How It Affected Brown v. Board of Education, 47-FEB Orange COUNTY LAw. 30, 32 (2005). Chief Justice Warren, the author of the Brown decision, was the Governor of California at the time of the Mendez case and ordered the California Attorney General to assist the plaintiffs in Mendez. Id. at 34. For a comparison of 
court granted an injunction and the Ninth Circuit affirmed the decision holding that the segregation of children of Mexican descent was a violation of the Fourteenth Amendment. ${ }^{491}$ The appellate court declined to base its ruling on the segregation cases ${ }^{492}$ which left the issue open for determination in Brown.

Brown heralded the end of de jure segregation-the "separate but equal" framework-in the United States. ${ }^{493}$ "But there is more yet to do." ${ }^{494}$ Today, African-American and Latino children are segregated in underfunded schools in the highest proportions since the 1960s. ${ }^{495}$ The recent United States Supreme Court decision in Fisher v. University of Texas, ${ }^{496}$ in which the Court reviewed under equal protection analysis a university program that considers race as a factor in admissions decisions, ${ }^{497}$ demonstrates that race and its impact on education remains an open issue. The Court did not rule on whether the program passes strict scrutiny analysis and remanded the case to the lower court for further review. ${ }^{498}$ The university argued that such programs are needed to remedy the legacy of racism in higher education and to increase diversity in the student body. ${ }^{499}$ Without affirmative action programs, universities may once again become segregated schools. The decisions made today with regard to education will decide the future of minority groups and of the nation - whether we move forward or move backward.

\section{Voting Rights}

Latinos and African Americans have also been successful in joining forces in the area of voting rights. ${ }^{500}$ In White v. Regester, ${ }^{501}$ Blacks and Mexican Americans successfully challenged a legislative reapportionment plan. ${ }^{502}$ The Supreme Court of the United States affirmed the portion of the district court's judgment that invalidated multimember districts in Dallas and Bexar Counties and ordered that the districts be redrawn into single-member districts because of the history of discrimination against Blacks and Mexican Americans. ${ }^{503}$ This was a seminal case in which minority groups success-

the similarities in the language used by Chief Justice Warren in Brown and the language used by Judge McCormick in Mendez $I$, see $i d$. at 36 .

${ }^{491}$ Mendez $I l, 161$ F.2d at 781.

492 Id. at $779-80$.

${ }^{493}$ Charles J. Ogletree, JR., All Deiliberate Speed 8, 316 (2005).

${ }^{494} \mathrm{Id}$. at 316.

${ }^{495}$ McKanders, Black and Brown Coalition Building, supra note 100, at 474.

496 133 S. Ct. 2411 (2013).

${ }^{497}$ Id. at $2415-22$.

${ }^{498} I d$. at $2419-22$.

${ }^{499}$ Id. at $2424,2426-27$.

${ }^{500}$ GonZalez, supra note 83 , at 178 .

${ }^{501} 412$ U.S. 755 (1973).

${ }^{502}$ Id. at 765 .

${ }^{503}$ Id. 
fully advanced "a claim that multimember legislative districts unconstitutionally diluted the voting strength of a discrete group." 504

The success of White was such that its holding as a vote dilution case was codified into the 1982 amendments to section 2 of the Voting Rights Act. ${ }^{505}$ In examining the history of race discrimination against Blacks, the Court found a lack of African-American representation in the White-dominated committee that controlled the Democratic Party's candidate slating in Dallas County. ${ }^{506}$ In examining the historical discrimination against Mexican Americans, the Court found that culture and language barriers made their participation in community processes extremely difficult and their "cultural incompatibility . . . conjoined with the poll tax and the most restrictive voter registration procedures in the nation ha[d] operated to effectively deny Mexican-Americans access to the political processes in Texas even longer than the Blacks were formally denied access by the white primary." 507

The recent United States Supreme Court decision in Shelby County v. Holder ${ }^{508}$ demonstrates the necessity for a coalition of African Americans and Latinos to lobby Congress for legislation that ensures voting rights for minorities. In Shelby County, the Court held that one of the sections of the Voting Rights Act, section 4(b), is unconstitutional because the coverage formula used to determine which states must meet preclearance (pre-approval) requirements before enacting changes to state election laws is based on old data and eradicated voting practices that may no longer apply in light of the current voting trends. ${ }^{509}$ During a speech before the National Urban League Conference in Philadelphia in 2013, U.S. Attorney General Eric Holder cited the current voter disenfranchisement of Latinos in Texas as one of the first challenges to be undertaken by the U.S. Department of Justice and called on civil rights organizations and everyday citizens to join forces in the fight for voting rights. ${ }^{510}$

During the 2012 election in Florida, the Republican leadership reduced the time for early voting by six days. ${ }^{511}$ This caused some voters to stand in long lines for hours. ${ }^{512}$ After the 2012 election, Republican legislators in North Carolina, where early voting has been a practice since 2000 , are trying

${ }^{504}$ City of Mobile v. Bolden, 446 U.S. 55, 68 (1980) (citing White, 412 U.S. at 766-67).

${ }^{505}$ See S. REp. No. 97-417 (1982) (legislating that proof of discriminatory intent is not required to establish a violation of section 2 of the Voting Rights Act and prohibiting any voting practice or procedure that results in discrimination).

${ }_{506}$ White, 412 U.S. at 766-67 (citing lower court's findings of fact).

${ }^{507} I d$. at 768 (citing lower court's findings of fact).

508133 S. Ct. 2612 (2013).

${ }^{509}$ Id. at 2631 .

${ }^{510}$ Holder Wants Texas Voting Laws to be Approved by U.S. Justice Dept., NBC10 PHILADEI.PHIA (July 25, 2013), http://www.nbcphiladelphia.com/news/local/Holder-to-Speak-inPhilly-About-Voting-Rights-Act-216882501.html (vowing to continue to fight against Texas voter ID laws).

${ }^{511}$ Rob Christensen, GOP Lawmakers' Efforts to Curtail Early Voting Draws Opposition, The News \& Obsterver (Raleigh, NC), Apr. 2, 2013, available at 2013 WLNR 8029174. ${ }^{512} I d$. 
to reduce the early voting period from two and half weeks to one week and also to end Sunday voting. ${ }^{513}$ Historically, $57 \%$ of North Carolinians take advantage of early voting. ${ }^{514}$ Democrats outnumbered Republican early voters during the 2008 and 2012 presidential elections in North Carolina, the state with the biggest gain in voter turnout between the 2004 and 2008 elections. ${ }^{515}$ The NAACP views the attack on early voting as a Republican tactic to disenfranchise Black voters. ${ }^{516}$ An African-American and Latino coalition in support of voting rights is of paramount importance to the political future of both groups.

\section{Immigration}

African-American politicians and an increasing number of Black citizens have been proactive in recent years in supporting immigrants on the issue of immigration reform. ${ }^{517}$ African-American civil rights leaders, such as Benjamin Todd Jealous, the President and Chief Executive Officer of the NAACP, openly advocate on behalf of comprehensive immigration reform. ${ }^{518}$ African-American Congressmen John Lewis, Keith Ellison, and Charles Rangel were arrested during a pro-immigration reform rally in Washington, D.C. in October 2013. ${ }^{519}$ But this was not always the case. ${ }^{520}$ Dr. Martin Luther King, Jr. softened the stance of Blacks on immigration. ${ }^{521}$ Some African-American leaders followed Dr. King's lead and, based on the ethos of compassion espoused by the Civil Rights Movement, advocated for unity with minority refugees and recognized a shared struggle for economic and political freedom. ${ }^{522}$ This "point of view, however, was not shared by all or perhaps even most blacks." 523 Black politicians who adopted Dr. King's "human rights perspective" on immigration in the 1980s, often went against the will of their constituencies. ${ }^{524}$ African-American politicians who

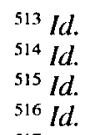

517 Sears, Sidanius \& Bobo, supra note 42, at 4. The Black Alliance for Just Immigration (BAJI) is an education and advocacy group of African Americans and Black immigrants that provides "the African American community with a progressive analysis and framework on immigration that links the interests of African Americans with those of immigrants of color." Mission and History, BLACK ALLIANCE FOR JUST IMMIGRATION, http://www.blackalliance.org/ mission-and-history/ (last visited Nov. 27, 2013). The organization was founded in response to the 2006 immigrant marches. $I d$.

${ }^{518}$ Benjamin Todd Jealous, No Second-Class Families, The HufFinciron Post (May 10, 2013), http://www.huffingtonpost.com/benjamin-todd-jealous/no-second-class-families_b_325 3713.html.

${ }^{519}$ Rep. John Lewis Among the Members of Congress Arrested at Immigration Rally, THE Rundown, PBS NewsHour (Oct. 8, 2013), http://www.pbs.org/newshour/rundown/2013/10/ john-lewis-arrested-at-immigration-rally.html.

${ }_{520}$ See discussion supra Part III.B-D.

${ }^{521}$ See Yans-McLaughidin, supra note 243, at 298.

522 Id.

${ }^{523} \mathrm{Id}$.

${ }^{524}$ See id. at 308. 
supported pro-immigrant policies in the 1980s and 1990s, at a time when most of the immigrants were poor people of color, identified the importance of coalitions with other minority groups. ${ }^{525}$ A civil rights and political coalition between African Americans and Latinos in support of the current comprehensive immigration reform movement appears promising ${ }^{526}$ and could serve to solidify future coalitions on other issues.

A successful African-American and Latino coalition around immigration policy came to fruition in Miami in the late 1990s when the groups rallied for a common cause - calling for immigration status for Haitian immigrants, most of them Black. ${ }^{527}$

If there is a silver lining here, it is that in South Florida, Nicaraguans, Cubans, African Americans, and others, have raised their voices on behalf of the Haitians. Groups that seldom, if ever, communicated in any meaningful way before, in part because each group was so busy trying to deal with its own problems, are now doing so and learning they have far more in common than differences, and that there is strength in unity. Moreover, Haitians and their advocates are calling for equal treatment for the Guatemalans, Salvadorans, Hondurans and others similarly situated as well. ${ }^{528}$

Recent efforts in Mississippi illustrate the power of African-American and Latino coalitions in support of issues of interest to both communities, including immigration. ${ }^{529}$ The growing numbers of African Americans returning to Mississippi in the 1990 s, coupled with a growing Latino population, provided a changing demographic that fostered the creation of the Mississippi Immigrants Rights Alliance (MIRA). ${ }^{530}$ In partnership with the state's Legislative Black Caucus, MIRA reached out to veterans of the civil rights and Black power movements to rally support for most of the progressive issues facing the state. ${ }^{531}$ This coalition was instrumental in defeating anti-immi-

${ }^{525}$ See id. at 307-10.

${ }^{526}$ The Leadership Conference on Civil and Human Rights recently released poll results showing that $60 \%$ of African Americans support immigration reform. Jenée Desmond-Harris, Who Said Blacks Don't Support Immigration Reform?, The Root (May 1, 2013), http://www .theroot.com/articles/culture/2013/05/black_support_for_immigration_reform_data.html?.

${ }_{527}$ Cheryl Little, Intergroup Coalitions and Immigration Politics: The Haitian Experience in Florida, 53 U. Miami L. Rev. 717, 739 (1999).

${ }^{528}$ Id.

${ }^{529}$ David Bacon, How Mississippi's BlackBrown Strategy Beat the South's Anti-Immigrant Wave, THE NATION (Apr. 20, 2012), http://www.thenation.com/article/167465/how-mis sissippis-blackbrown-strategy-beat-souths-anti-immigrant-wave.

${ }_{530}$ Id.

${ }^{531}$ Susan Eaton, A New Kind of Southern Strategy, The Natron (Aug. 10, 2011), http:// www . thenation . com/article/162694/new - kind - southern - strategy. Black activist Chokwe Lubumba joined with MIRA in support of Latino immigrants because he recognized that "Latinos have become targets of the same white supremacy levied at African Americans for generations." Black Activist Gets Kudos for Helping Immigrants, MinOrTTY News (Jan. 20, 2014), http://www.blackradionetwork.com/ms_civil_rights_activist_honored_for_immigrant_work. 
grant legislation. ${ }^{532}$ The proposed state immigration law was intended to drive Latino immigrants out of Mississippi and would have been a blow to the minority coalition strategy. ${ }^{533}$ Black politicians recognized the efforts to dilute the power of the coalition and fought relentlessly and successfully against the Arizona-style immigration law, thereby ensuring the future of the Black-Latino political coalition, which continues to fight against voter ID measures and other proposed legislation aimed at disenfranchising African Americans and Latinos. ${ }^{534}$

A similar coalition emerged in Alabama where African Americans and Latinos held hands at a rally and sang We Shall Overcome in protest of Alabama's immigration law H.B. 56. ${ }^{535}$ In industries where recent immigrants work alongside African Americans in low-skilled jobs, there have also been successful worker coalitions in Central Mississippi, North Carolina, and Tennessee..$^{536}$ Unfortunately, successful coalitions do not get the media coverage that is often devoted to publicizing the divisions between the groups. ${ }^{537}$ Coalition-building must continue on issues of common interest, such as political representation, and on issues of special interest to each group, such as immigration, an issue that is currently defining the Latino experience in the United States.

\section{CONCLusion}

In his 2014 State of the Union address, President Obama said: "Let's make this a year of action." 538 African Americans and Latinos profit from forming coalitions for the benefit of both groups and American society in general. ${ }^{539}$ Comprehensive immigration reform may be the means to test the possibilities and the power of African American and Latino coalitions. Coalition-building is strenuous and must be conducted with respect and caution. ${ }^{540}$ Groups and individuals must make a conscious effort to find "safe

${ }^{532}$ Bacon, supra note 529.

${ }^{533} \mathrm{Id}$.

${ }^{534} \mathrm{Id}$.

${ }^{535}$ Naeesa Aziz, Alabama Immigration Law Unites Blacks, Latinos, BET (Oct. 23, 2011 12:18 PM), http://www.bet.com/news/nationa1/2011/10/23/alabama-immigration-law-unitesblacks-latinos.html.

${ }_{536}$ See Gordon \& Lenhardt, supra note 466, at 19-38.

${ }^{537}$ See id. at ii, 1-2, 19. See also Montoya \& Valdes, supra note 29, at 190 (explaining that the history of cooperation among inter-racial groups has not been adequately studied).

${ }_{538}$ President Barack Obama, President Barack Obama's State of the Union Address (Jan. 28, 2014), http://www.whitehouse.gov/the-press-office/2014/01/28/president-barack-obamasstate-union-address.

${ }^{539}$ In their book, The Miner's Canary, Professors Lani Guinier and Gerald Torres offer what has been characterized by Professor Richard Delgado as an "outstanding, breakthrough idea." Delgado, Linking Arms, supra note 181, at 864 . They posit that disadvantaged groups should lead the way in coalition-building and in the fight against social injustice. See id. (citations omitted).

540 Bernice Johnson Reagon, Coalition Politics: Turning the Century in Home Giris: A Black FEMINIST ANIHOLOGy 356-368 (Barbara Smith ed., 1983) reprinted in Perea, Deigado, Harris, Stefancic \& Wildman, supra note 114, at 1213-17. 
spaces" where they can engage beyond their own groups in order to facilitate cultural exposure and collaboration, which lead to an increased understanding of people of different races, ethnicities, and cultures; this increased understanding should be accompanied by mutual respect. ${ }^{541}$ To reach consensus, African Americans and Latinos have to be open to dialogue, willing to learn about each other's experiences, committed to recognizing each other's contributions, ready to embrace the differences along with the similarities, and eager to bake a larger American pie to be shared equitably by all people in this nation. Racial tensions should not be ignored. ${ }^{542}$ Americans in general must resist the tendency to entrench within their own groups, "hunker down,' or 'pull in like a turtle," in reaction to the presence of people of different races and ethnicities. ${ }^{543}$

Community and political advocates and activists must emulate the example of leaders like César Chávez ${ }^{544}$ who acknowledged "the connections and the similarities among the struggles of Latinos, Blacks, Jews, and other minorities." ${ }_{45}$ Indeed, all communities in the United States must be ready to work and march together on the path towards the dream of Dr. Martin Luther King, Jr. of civil rights and equality for all. As Dr. King explained it: "We are caught in an inescapable network of mutuality, tied in a single garment of destiny. Whatever affects one directly, affects all indirectly." ${ }^{546}$ Therefore, we must recognize that what is good for the currently marginalized minorities is good for all people in the United States; this might be the ultimate redemption for our nation.

Those who are racially marginalized are like the miner's canary: their distress is the first sign of a danger that threatens us all. It is easy enough to think that when we sacrifice this canary, the only

${ }^{541}$ See Wolff, supra note 134 , at 784.

${ }^{542}$ The casebook, Latinos and the Law, devotes a fourteen-page section of the book to "interracial tensions and relations." Delgado, Perea \& Strefancic, supra note 446, at 189 203.

${ }^{543}$ See Kenji Yoshino, The New Equal Protection, 124 Harv. L. Rev. 747, 753 (2011).

${ }^{544}$ Chávez is considered a leader by many Latinos in their fight for racial justice in a similar way as Dr. King is considered a leader by African Americans. Charles J. Ogletree, Jr., The Quiet Storm: The Rebellious Influence of César Chávez, 1 HARv. LAT. L. Rev. 1, 2 (1994) (citing George Ramos, Cesar Chavez Dies: Legendary Labor Leader Founded UFW, L.A. Times, Apr. 25, 1993, at Al). The César Chávez motion picture, released on March 28, 2014, may help to educate Americans about the story of this prominent American civil rights activist and labor organizer. See Cesar Chavez, FACEBOOK, https://www.facebook.com/ CesarChavezMovie (last visited Mar. 12, 2014). The film has drawn some criticism. Ruben Navarretrte JR., The Chávez Not Likely Depicted in Upcoming Film, The Monitor (March $23,2014)$, http://www.themonitor.com/opinion/commentary-the-ch-vez-not-likely-depicted-inupcoming-film/article_e18d7aba-b110-11e3-8eb3-0017a43b2370.html.

${ }^{545}$ Id.

546 McKanders, Black and Brown Coalition Building, supra note 100, at 473 (quoting Martin Luther King, Jr., letter from Birmingham City Jail, 1963 in A TEsTAMENT OF HoPE: The Essential Writings and Speeches of Martin Luther Kingi, JR. 290 (James Melvin Washington ed., 1986)). 
harm is to communities of color. Yet others ignore problems that converge around racial minorities at their own peril, for these problems are symptoms warning us that we are all at risk. ${ }^{547}$ 